\title{
Need to Seed? Ecological, Genetic, and Evolutionary Keys to Seed-Based Wetland Restoration
}

\author{
Karin M. Kettenring* and Emily E. Tarsa \\ Department of Watershed Sciences and Ecology Center, Utah State University, Logan, UT, United States
}

As we approach the Decade of Ecosystem Restoration (2021-2030), there is renewed focus on improving wetland restoration practices to reestablish the habitat and climate mitigation functions and services that wetlands provide. A first step in restoring these functions and services is to reestablish the native vegetation structure and composition through strategic seed-based approaches. These approaches should be driven by ecological, genetic, and evolutionary principles, along with consideration for economics, logistics, and other social constraints. Effective seed-based approaches must consider the chosen species, seed sourcing, dormancy break and germination requirements, seed enhancement technologies, potential invaders, seeding densities, and long-term monitoring. Choice of species should reflect historical plant communities and future

OPEN ACCESS

Edited by:

Anne Alje Van Dam,

IHE Delft Institute for Water

Education, Netherlands

Reviewed by:

Teresa Ferreira,

University of Lisbon, Portugal

Angelino Carta,

Department of Biology, University

of Pisa, Italy

*Correspondence:

Karin M. Kettenring

karin.kettenring@usu.edu

Specialty section:

This article was submitted to

Freshwater Science,

a section of the journal

Frontiers in Environmental Science

Received: 06 September 2019

Accepted: 23 June 2020

Published: 18 August 2020

Citation:

Kettenring KM and Tarsa EE (2020) Need to Seed? Ecological,

Genetic, and Evolutionary Keys to Seed-Based Wetland Restoration.

Front. Environ. Sci. 8:109.

doi: 10.3389/fenvs.2020.00109 environmental conditions, species that support functional goals including invasion resistance, and seed availability constraints. Furthermore, seeds should be sourced to ensure ample genetic diversity to support multifunctionality and evolutionary capacity while also considering the broad natural dispersal of many wetland species. The decision to collect wild seeds or purchase seeds will also impact species choice and genetic diversity, which can have cascading effects for functional goals. To ensure seedling establishment, seed dormancy should be addressed through dormancy breaking treatments and the potentially narrow germination requirements of some species will require targeted sowing timing and location to align with safe sites. Other seed enhancements such as priming and coatings are poorly developed for wetland restoration and their potential for improving establishment is unknown. Because wetlands are highly invasion prone, potential invaders and their legacies should be addressed. Seeding densities should strike a balance between outcompeting invaders and preserving valuable seed resources. Invader control and long-term monitoring is key to improving revegetation and restoration. Here, we review scientific advances to improve revegetation outcomes, and provide methods and recommendations to help achieve the desired goals. Gaps in knowledge about seed-based wetland restoration currently exist, however, and untested practices will certainly increase risks in future efforts. These efforts can be used to better understand the ecological, genetic, and evolutionary processes related to wetland seeds, which will bring us one step closer to seed-based restoration of functions and services needed for human and ecological communities.

Keywords: genetic and species diversity, revegetation, seed dormancy, seed germination, seed provenance, seed sourcing, seed sowing, seed technology 


\section{INTRODUCTION}

The United Nations declared 2021-2030 as the Decade on Ecosystem Restoration (Eisele and Hwang, 2019). Priorities of this initiative include mitigating biodiversity and land degradation, protecting food chains in mangroves, sustainably managing nitrogen to improve water quality, sustainably managing peatlands to mitigate climate change, and supporting a blue economy. To address these priorities wetland restoration must be an integral part of their efforts.

Wetlands provide essential ecosystem functions and services such as supporting biodiversity for conservation, providing habitat to support hunting and fisheries, improving water quality for downstream waters, combatting sea level rise, protecting coastlines, and mitigating the effects of flooding, drought, and climate change (Zedler and Kercher, 2005; Brander et al., 2013; Duarte et al., 2013; Bouma et al., 2014; Espeland and Kettenring, 2018; Benson et al., 2019; Qu et al., 2019). But historically wetlands were viewed as wastelands and have been heavily impacted by humans, resulting in a loss of more than half of wetlands globally with significant impacts and risks to wildlife, humans, and economies (Zedler and Kercher, 2005; EndterWada et al., 2018, 2020). While there is an urgent need to restore wetlands, fully recovering the functions and services of target reference wetlands has been an elusive restoration outcome (Benayas et al., 2009; Moreno-Mateos et al., 2012; Meli et al., 2014).

Employing strategic seed-based approaches in wetland restoration is a first step to more quickly and completely recover the underlying vegetation structure and composition that supports these vital functions and services. Seed-based approaches are less expensive and more logistically feasible in treating larger areas than other wetland revegetation techniques (e.g., planting plugs, transplanting rhizomes, and installing sod mats) despite the high cost of native seed (Godefroid et al., 2011; Merritt and Dixon, 2011; Broadhurst et al., 2016; Nevill et al., 2018). However, seeding results can be unpredictable and mortality high (Drayton and Primack, 2000, 2012; Tilley and Hoag, 2006; Godefroid et al., 2011; Peralta et al., 2017; Matthews et al., 2019; Sloey and Hester, 2019; Greet et al., 2020). The seed and seedling stages of plants are a demographic bottleneck and often few seeds survive to become seedlings (Figure 1; Leck et al., 2008; Palma and Laurance, 2015).

An effective seed-based approach should be driven by ecological, genetic, and evolutionary principles, along with consideration for economics, logistics, and other social constraints (Figure 2). Best practices for seed-based restoration that address limiting environmental factors and inform strategic management interventions are imperative for improving revegetation outcomes (James and Carrick, 2016). Recent reviews have highlighted approaches for seeding dryland and forest ecosystems (e.g., Kildisheva et al., 2016; Grossnickle and Ivetić, 2017), but there are few synthetic comprehensive reviews for seed-based restoration of wetlands (but see Marion and Orth, 2010 on seagrasses), and much of the guidance is broadly scattered throughout the peer-reviewed and gray literature.

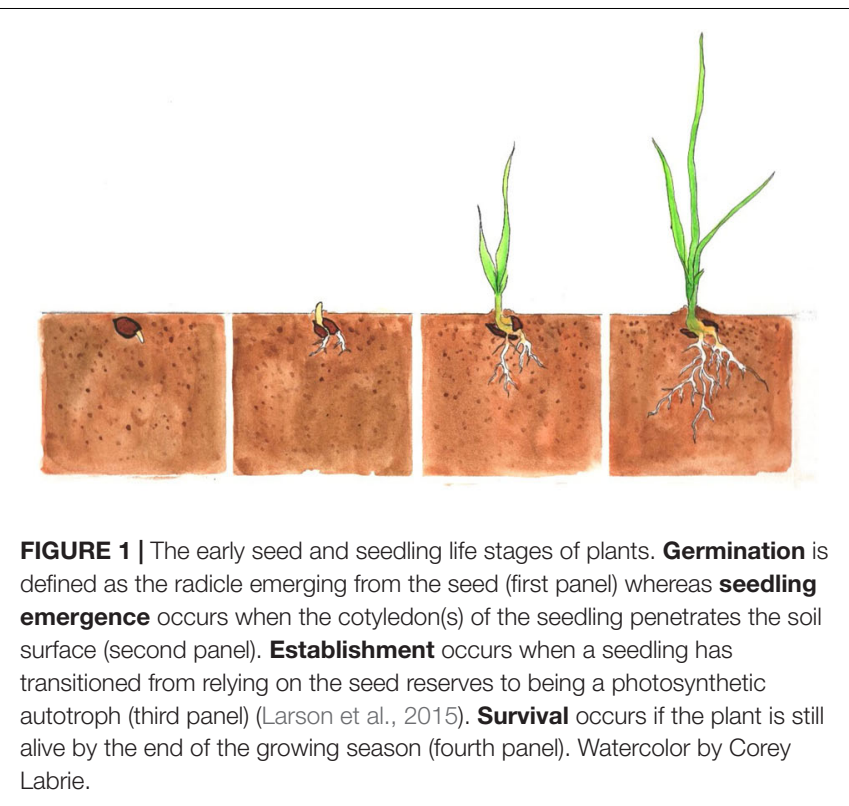

Here we synthesize the latest knowledge in seed-based wetland restoration and explore common challenges and potential solutions. Our review broadly spans the various types of wetlands, including seagrass meadows, coastal marshes (salt, brackish, and freshwater tidal), forested wetlands (riparian, floodplain, bottomland hardwood, mangroves), and inland freshwater and saline wetlands (emergent wetlands, sedge meadows, wet prairies, fens, vascular plants in bogs, and temporary or seasonal wetlands like vernal pools and mudflats). We highlight how seed-based wetland restoration can be improved by better incorporating ecological, genetic, and evolutionary principles. We focus on issues related to seed acquisition (section "Seed Acquisition") and preparation (section "Seed Preparation") including choice of species and seed sources, seed collections, and seed treatments. We also address critical aspects of site preparation (section "Site Preparation") and seeding (section "Seeding") including constraints to seedling survival, seeding densities and approaches, germination safe sites as well as invasive species issues and the essential role of monitoring (section "Maintenance and Monitoring"). But first, when is seeding appropriate?

\section{FACTORS INFLUENCING THE NEED TO SEED}

When considering a seed-based approach to wetland restoration, it is important to first decide if seeding is needed. If aspects of the site or landscape context indicate that native plant communities naturally reestablishing will be species-poor or genetically depauperate, or slow to recover (section "Site and Landscape Context"), then choose to seed. If invasive species are likely to rapidly invade a restoration and preempt recolonizing native plants (section "Nutrient Enrichment and Invasive Species Impacts"), then choose to seed. If restoration goals 


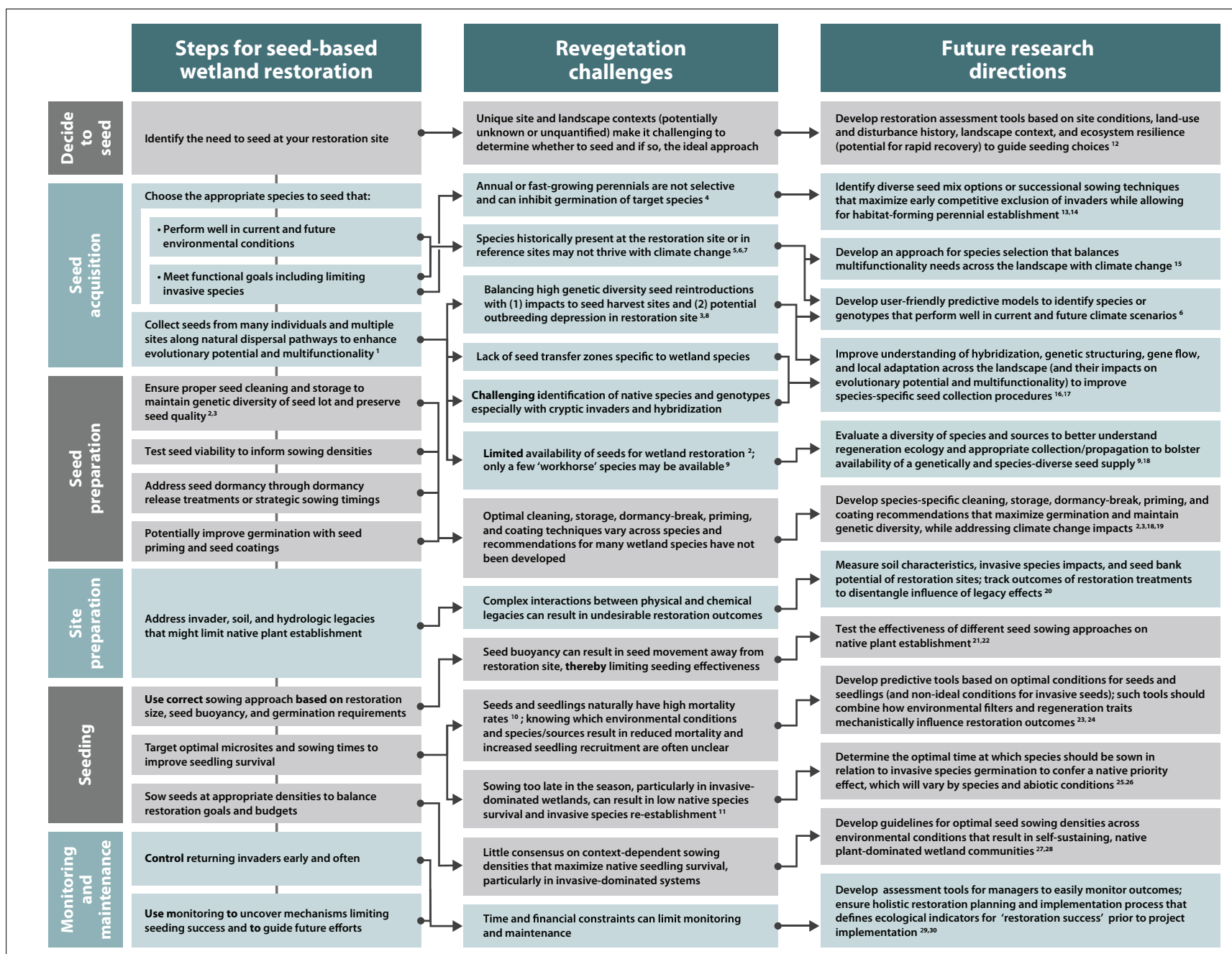

FIGURE 2 | For each step of seed-based wetland restoration, significant revegetation challenges persist and there are numerous opportunities for future research directions. ${ }^{1}$ (Broadhurst et al., 2008); ${ }^{2}$ (Merritt and Dixon, 2011); ${ }^{3}$ (Basey et al., 2015); ${ }^{4}$ (Perry and Galatowitsch, 2004); ${ }^{5}$ (Suding, 2011); ${ }^{6}$ (Butterfield et al., 2017); ${ }^{7}$ (Havens et al., 2015); ${ }^{8}$ (Hufford and Mazer, 2003); ${ }^{\text {}}$ (Broadhurst et al., 2016); ${ }^{10}$ (James et al., 2011); ${ }^{11}$ (Hess et al., 2019); ${ }^{12}$ (Holl and Aide, 2011); ${ }^{13}$ (Byun et al., 2013); ${ }^{14}$ (Doherty et al., 2011); ${ }^{15}$ (Oliver et al., 2015); ${ }^{16}$ (Kettenring et al., 2019b); ${ }^{17}$ (McKay et al., 2005); ${ }^{18}$ (White et al., 2018); ${ }^{19}$ (Walck et al., 2011 ); ${ }^{20}$ (Peralta et al., 2017); ${ }^{21}$ (Tilley and Hoag, 2006); ${ }^{22}$ (Unsworth et al., 2019); ${ }^{23}$ (Larson and Funk, 2016); ${ }^{24}$ (Zirbel and Brudvig, 2020); ${ }^{25}$ (Daniel et al., 2019$) ;{ }^{26}$ (Cleland et al., 2015); ${ }^{27}$ (Reinhardt Adams and Galatowitsch, 2008); ${ }^{28}$ (van Katwijk et al., 2016); ${ }^{29}$ (Smith-Cartwright and Chow-Fraser, 2011); ${ }^{30}$ (Taddeo and Dronova, 2020).

require genetically diverse and species-diverse plant communities (section "Ecological, Genetic, and Evolutionary Benefits of Seeding"), and that diversity might not recover naturally, then choose to seed.

\section{Site and Landscape Context}

Aspects of site and landscape conditions (potentially unknown or unquantified) drive how readily native plant communities will recolonize (Figure 2). Existing native vegetation on-site (i.e., remnant patches) or in adjacent wetlands can rapidly expand into restorations (Galatowitsch and van der Valk, 1996; Wolters et al., 2008). Also, many wetlands have diverse seed banks, and these can be sources for plant recovery depending on the length of wetland drainage, intervening land-use history, extent of excavation, and on-going effects of climate change (Wienhold and van der Valk, 1989; Middleton, 2003; Walck et al., 2011;
McLane et al., 2012; Dawson et al., 2017, 2020; Winikoff et al., 2020). A cursory site assessment for remnant vegetation and a straightforward seed bank assay can indicate whether these seed sources are sufficient to make seeding unnecessary (Grewell et al., 2019; Sloey and Hester, 2019). However, seed bank composition and density can be spatially and temporally variable so a welldesigned sampling approach is needed to ensure the seed bank assay is sufficiently informative (Leck and Brock, 2000; Orth et al., 2000; Leck and Schütz, 2005).

Nearby wetlands in relatively intact landscapes can also serve as propagule sources, and seemingly isolated wetlands may be highly connected via bird seed dispersers, non-channelized surface flow, and channelized streamflow (Santamaría, 2002; Nilsson et al., 2010; Soons et al., 2016; Alexander et al., 2018; Leibowitz et al., 2018). However, with landscape fragmentation, historical (often hydrologic) connectivity among wetlands can be 
severed, and the number of arriving seeds is often too limited and lacking native diversity to support rapid plant community recovery (Galatowitsch and Richardson, 2005; Galatowitsch, 2006; Mazerolle et al., 2006; Kettenring and Galatowitsch, 2011b; Donnelly et al., 2020).

\section{Nutrient Enrichment and Invasive Species Impacts}

Nutrient enrichment and invasive species are two other important considerations for deciding to seed. Wetlands, as landscape sinks, are highly prone to invasion and simultaneously also accumulate nutrients that fuel further invasions (Davis et al., 2000; Zedler and Kercher, 2004). Therefore, the species that often recolonize new wetland restorations are disturbance specialists that thrive on these conditions (Galatowitsch et al., 1999). A key advantage of taking an aggressive seed-based approach to wetland restoration is to preempt the (re)invasion of undesirable species (section "Priority Effects"; Hess et al., 2019).

\section{Ecological, Genetic, and Evolutionary Benefits of Seeding}

Seeding also has the advantage of mimicking natural ecological and evolutionary processes for many wetland species. A common misconception is that the perennial dominants of many wetlands rely mostly on clonal reproduction (e.g., tillers, rhizomes, and turions). However, genetic assessments have determined that many wetland plants actually have high levels of genetic diversity within sites such as Potamogeton pectinatus [now Stuckenia pectinata (L.) Börner; Hangelbroek et al., 2002; Triest and Fenart, 2014], Nymphoides fallax Ornduff (Lobato de Magalhães et al., 2020), N. peltata (Gmel.) O. Kuntza (Liao et al., 2013), and Bolboschoenus (Asch.) Palla and Schoenoplectus (Rchb.) Palla species (Sweetman et al., 2013; Kettenring et al., 2019b). Such findings indicate that sexual reproduction is naturally quite common. In addition, little genetic differentiation among populations has been found for many wetland species, which is an indicator of high gene flow among wetlands via seeds (Santamaría, 2002; Pollux et al., 2009; Nilsson et al., 2010; Sweetman et al., 2013; Ngeve et al., 2017; Orsenigo et al., 2017; Kettenring et al., 2019b; Lobato de Magalhães et al., 2020).

Seeding also allows for the inclusion of higher numbers of species and genotypes relative to the more logistically intensive planting process (Godefroid et al., 2011; Reynolds et al., 2012). Higher genetic diversity is critical for the ability of plants to evolve in response to future changes, and both genetic and species diversity are essential to support ecosystem multifunctionality (section "Seed Source Diversity"), i.e., the simultaneous support of multiple ecosystem functions (Bischoff et al., 2010; Reynolds et al., 2012; Kettenring et al., 2014; Palma and Laurance, 2015; Espeland et al., 2017; Zeldin et al., 2020).

\section{SEED ACQUISITION}

Achieving restoration goals requires careful consideration of the species composition of seed mixes (section "Species Composition of the Seed Mix") and seed source diversity (section "Seed Source
Diversity"). Control over the species and genetic diversity of seed mixes depends, in part, on whether seeds are wild-collected or purchased (section "Wild-Collecting vs. Purchasing Seeds"). With wild-collecting, practitioners must carefully consider where and how much seed to collect (section "Seed Collection Locations and Amounts") as well as when and how to collect seeds (sections "Seed Collection Timing" and "Seed Collection Approaches").

\section{Species Composition of the Seed Mix Species Choices Based on Historical Plant} Communities and Future Environmental Conditions

Many practitioners have the goal of returning wetlands to their previous pre-disturbance state, which is often centered on reintroducing native species that historically existed on a site or what is present in nearby reference ecosystems with similar environmental conditions (Allen et al., 2001; Sullivan, 2001; Thampanya et al., 2002). Recreating historical plant communities requires that the site provides suitable environmental conditions (e.g., flooding, anoxia, drought, salinity, and physical disturbance) that align with tolerances of target species. However, a subset of what is sown may be filtered out if there is a mismatch between species' environmental tolerances and site conditions (Figure 3A; Rieger et al., 2014).

Environmental filtering of species is likely to become more extreme with climate change and many target species may not survive under future environmental conditions. Therefore, "prestoration" of species that will do well in a restoration under current and future conditions may be necessary to establish a self-sustaining plant community (Figure 3B; Jump and Peñuelas, 2005; Butterfield et al., 2017).

\section{Choosing Native Plants for Functional Goals Including Invasion Resistance}

Society demands that wetland restorations are often linked to valued ecosystem services (section "Introduction"). Thus, seed mixes should include a diversity of species that support ecosystem functioning (i.e., multifunctionality) and ecosystem services valued by society (Kettenring et al., 2014; Laughlin, 2014).

Given the far-reaching impacts of wetland invasions, limiting future invaders (i.e., the ecosystem function of biotic or invasion resistance; Levine et al., 2004) should be considered when designing seed mixes. Reintroducing a diversity of species, particularly those that can best "fill the space" and limit light, nutrients, and even water for future invaders, is ideal (Figure 3C; Shipley et al., 1989; Shipley and Parent, 1991; Iannone and Galatowitsch, 2008; Byun et al., 2013, 2018; Hess et al., 2019; Matthews et al., 2019).

A suite of fast-growing plants (usually annuals) can be effective at resource pre-emption (e.g., Byun et al., 2013, 2015). However, in some wetland systems the use of annuals as "cover crops" had undesired effects. The cover crops did not suppress species selectively and inhibited the establishment of desired native, habitat-forming, perennial species (Perry and Galatowitsch, 2003; Perry et al., 2004; Iannone and Galatowitsch, 2008; Borkenhagen and Cooper, 2019). More research is warranted to identify species that offer selective suppression of wetland invaders (Figure 2). Furthermore, other techniques to 


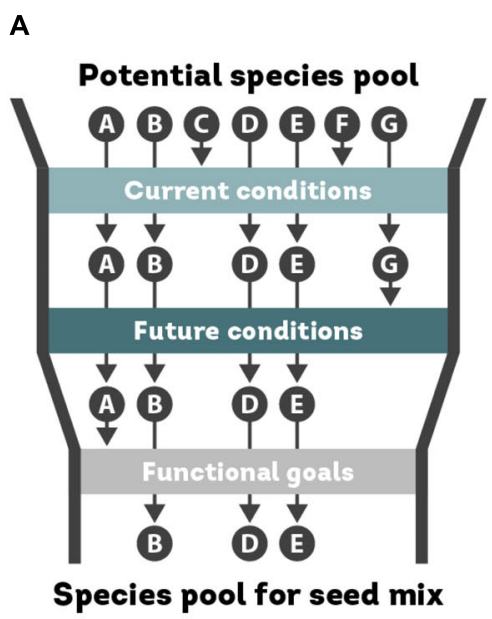

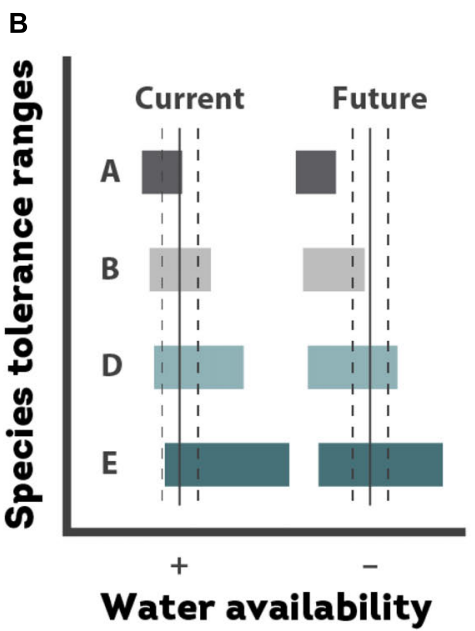
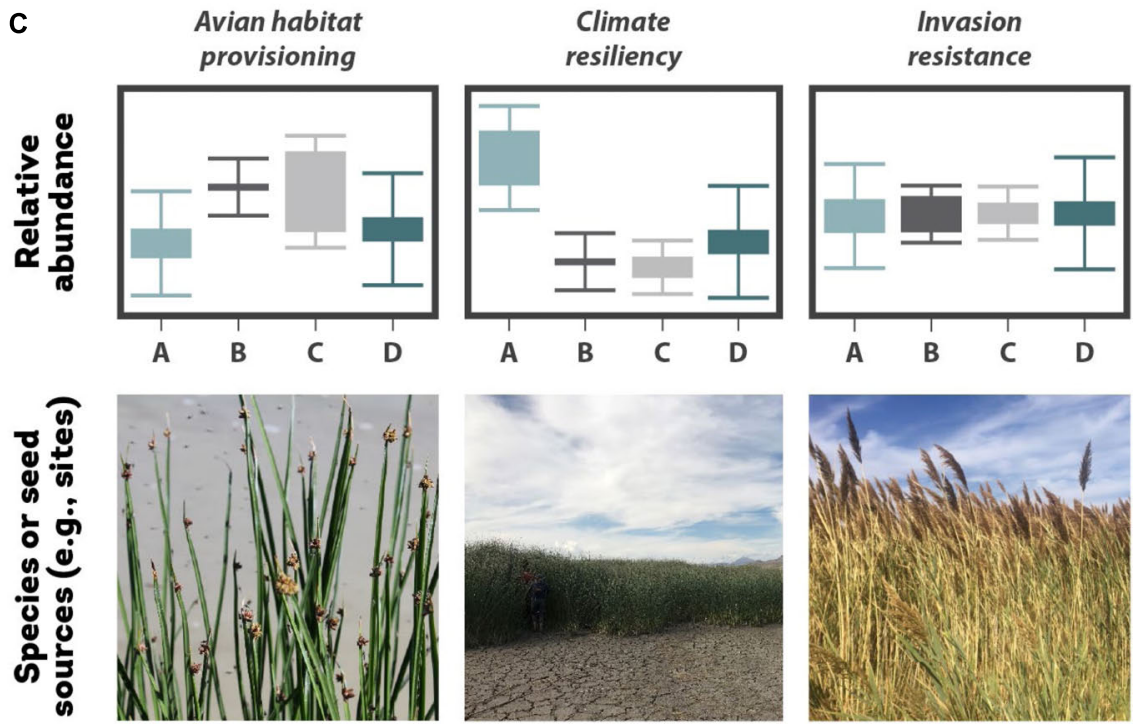

FIGURE 3 | (A) Choosing species from a species pool (A through G) to introduce to a wetland restoration site involves sequentially considering each species' ability to exist at the site in current and future climate conditions and the functional goals of the restoration project. A subset of species A-G pass through the first filter in seed mix design based on their ability to tolerate current and future environmental conditions at the site. Next the species pool is whittled down based on different species' ability to provide desired functional goals; (B) future conditions at the site might shift to a drier state, thus excluding species A entirely (adapted from Walck et al., 2011, with permission from John Wiley and Sons); (C) the relative proportion of different species (A-D) should reflect functional goals of the restoration (adapted from Laughlin, 2014, with permission from John Wiley and Sons). Such goals might include provisioning of wildlife habitat (i.e., choosing species that provide high-quality food sources or nesting habitat); resilience to future climate shifts (e.g., choosing species that can best survive with predicted shifts in precipitation or temperature); and invasion resistance by fostering niche complementarity with a combination of native species that maximize resource use and limit resources like light for the invader. Alternatively, if a single native species is known to be a strong competitor against an invader (e.g., based on the limiting similarity hypothesis; Funk et al., 2008), then that species should be reintroduced at a much higher rate and the relative proportions might look more like what is depicted in the climate resiliency scenario. At the sub-species level, different seed sources (again, A-D) may fulfill different functional roles due to different evolutionary histories and local adaptation and thus their relative proportions in seed mixes can be intentionally manipulated to optimize desired phenotypic traits and related functional goals.

increase establishment of habitat-forming perennial species such as completely breaking seed dormancy and improving germination and establishment conditions - may be as conducive to supporting biotic resistance as introducing fast growing annuals (Iannone and Galatowitsch, 2008; Lishawa et al., 2019; Rosbakh et al., 2019).

\section{Constraints of Seed Availability}

A diverse seed mix will ultimately be constrained by budgets and seed availability (i.e., the "restoration species pool" sensu Ladouceur et al., 2018). "Workhorse" species may be readily available while species that are rare, expensive, difficult to propagate, or simply poorly researched (e.g., dormancy-breaking 
or germination requirements) will be harder to obtain and reestablish (Figure 2; Kettenring and Galatowitsch, 2007a; Broadhurst et al., 2016; White et al., 2018; Hancock et al., 2020; Hugron et al., 2020). However, acquiring these species is important to avoid the homogenization of restored communities and loss of multifunctionality linked to those species (Palma and Laurance, 2015; Broadhurst et al., 2016; Ladouceur et al., 2018; White et al., 2018).

\section{Seed Source Diversity}

In addition to choosing which species to sow at a site, the decision of where to source seeds has ecological, genetic, and evolutionary implications for wetland restoration. Specifically, developing a seed mix with high levels of genetic diversity is essential to increase plant establishment, survival, and fitness (Godefroid et al., 2011; Aavik et al., 2012; Jordan et al., 2019). Furthermore, high genetic diversity can increase the ability of plants to adapt to local conditions and result in a plant community and native seed bank with high evolutionary potential under a changing climate (Rice and Emery, 2003; Broadhurst et al., 2008; Leimu and Fischer, 2008; Espeland et al., 2017).

Genetic diversity is also important for community and ecosystem processes (Whitham et al., 2003; Hughes et al., 2008), including higher primary productivity, invasion resistance, and ecosystem resilience that allows for communities to withstand episodic disturbances (Figure 3C; Reusch et al., 2005; Kotowska et al., 2010; Vellend et al., 2010). Because some wetland types are characterized by monotypic stands with low species diversity (Bruno and Bertness, 2001), it is particularly crucial to incorporate genetically diverse seed mixes to maximize the adaptive potential and ecosystems functions that wetland species can provide (Rice and Emery, 2003; Kettenring et al., 2014).

In addition to genetic diversity, phenotypic plasticity of a species (i.e., the ability of a species to change its morphology or physiology in response to the environment; Ghalambor et al., 2007) can facilitate its adaptive capacity. Phenotypic plasticity is particularly important in the context of climate change as it can influence species distribution and facilitate rapid evolution in response to changing environmental conditions (Sultan et al., 1998; Rice and Emery, 2003; Chevin et al., 2010; Havens et al., 2015). In ecosystems that are highly variable, as in wetland ecosystems, plasticity is expected to be high (Scheiner and Holt, 2012; King and Hadfield, 2019), and phenotypic differences between wetland plant populations may be less pronounced as compared to other ecosystems. However, because plasticity can have a genetic basis and can be driven by the maternal environment, subject to strong selection, and structured across the landscape, it should be considered for seed sourcing to ensure adequate sampling of plastic trait variation (section "Seed Collection Locations and Amounts"; Donohue et al., 2010; Walck et al., 2011; Espeland et al., 2018; Su et al., 2018).

\section{Wild-Collecting vs. Purchasing Seeds}

The choice to wild collect or purchase seeds for restoration is based on ecological, genetic, and logistical factors. The simplest approach (although not necessarily the most cost effective) is to purchase seeds. However, unlike many terrestrial species, wetland seeds are not generally cultivated by native plant growers in farm settings or seed production areas (Nevill et al., 2016; Espeland et al., 2017; Hancock et al., 2020). Also, fortuitously, they are rarely bred and propagated as cultivars with potentially undesirable traits and reduced genetic diversity (Schröder and Prasse, 2013; Kettenring et al., 2014; Leger and Baughman, 2015; Breed et al., 2018).

Thus, wetland seeds often must be wild-collected prior to purchase, a process with potentially large negative impacts to wild populations (section "Seed Collection Locations and Amounts"; Hancock et al., 2020). However, the ability to purchase seeds assumes that the target species are available, with sufficient genetic diversity, and sourced from appropriate areas (e.g., desired provenance, the ecogeographic seed source region with particular genetic material of target local adaptation, which in reality is rarely known particularly for wetland species; Figure 2; Broadhurst et al., 2008; Breed et al., 2018). Unfortunately, only a fraction of native wetland species are sold by native plant vendors, and species that are hard to collect, store, and propagate, or are rare, may be unavailable or prohibitively expensive (ENSCONET, 2009; Rivière et al., 2018; White et al., 2018; Rantala-Sykes and Campbell, 2019). Seeds that are source-certified with a known provenance are even harder to acquire (Tischew et al., 2011; Mainz and Wieden, 2019). However, with adequate lead time, some native plant vendors can acquire desired species or collect from particular seed sources to meet provenance requirements (Apfelbaum and Haney, 2012). Furthermore, ambitious native seed banking initiatives such as the European Native Seed Conservation Network (ENSCONET) and Seeds of Success (SOS) in the United States - a massive native seed collection program led by the Bureau of Land Management with many agency and non-profit partners - are working to improve access to genetically diverse native seed for research, conservation, and restoration plant materials development (ENSCONET, 2009; Haidet and Olwell, 2015; Rivière et al., 2018; Barga et al., 2020).

Species identification with native vendors can be an issue, particularly for species with co-occurring subspecies and for wetland graminoids that can have subtle morphological differences or can hybridize (the latter can be particularly challenging when target native species and genotypes may be difficult to distinguish from cryptic invaders; Saltonstall, 2002; Blum et al., 2010; Travis et al., 2010; Rieger et al., 2014; Kettenring et al., 2019a). In addition, while there are many excellent native plant vendors, not all are reputable (a lesson often learned through word of mouth or bad luck) and estimates of seed lot viability, purity, or age may be inaccurate or vary widely in quality (Apfelbaum and Haney, 2012; Rieger et al., 2014; Marin et al., 2017). Thus, the onus is on the practitioner to have quality control practices, such as retesting seed viability.

Practitioner-friendly tools exist to help with decisions regarding whether to wild collect or purchase seed. RantalaSykes and Campbell (2019) developed a scoring system for species based on ease of collection (e.g., regional occurrence, local abundance, ease of species identification), cleaning requirements (e.g., need for specialized equipment), storage needs (e.g., desiccant-tolerant seeds), and propagation (e.g., treatments for seed dormancy break). We address each of these issues 
related to wild-collecting seeds in the following sections. Wild collecting seeds for restoration, albeit time consuming, does provide increased control over the species and genetic diversity of a seed mix.

\section{Seed Collection Locations and Amounts}

The extent of genetic diversity, plasticity, functional diversity, and local adaption in a restoration seed mix is important for achieving restoration goals. These factors are driven by the interaction of the plant breeding system, mode of reproduction, dispersal mechanism, population size, and gene flow with site environmental conditions, landscape configuration, and anthropogenic impacts to sites and landscapes (Broadhurst et al., 2008; Scheiner and Holt, 2012; Coppi et al., 2015). To achieve the desired seed mix characteristics, consideration must be given to how many and which populations and individual plants to collect seeds from.

\section{Number and choice of populations}

Seed collecting from multiple populations is necessary for a genetically diverse seed mix (ENSCONET, 2009; Bureau of Land Management, 2018; Jordan et al., 2019) although the minimum number of populations required will vary by species, site conditions, and degree of landscape fragmentation. Recommendations suggest targeting a minimum of 5-20 populations (ENSCONET, 2009; Bureau of Land Management, 2018). More populations will be needed for outcrossing species whose genetic diversity is higher among rather than within populations (Espeland et al., 2017) as well as for populations in highly fragmented landscapes with genetically depauperate, relict populations.

A range of approaches has been proposed for seed collections with different priorities to maximize genetic diversity of a seed lot, adaptive potential to the restoration site, or future adaptation with climate change (Havens et al., 2015; Prober et al., 2015; Booth, 2016; Broadhurst et al., 2016). Breed et al. (2013) developed a "provenance strategy decision tree" to aid decisionmaking on the choice of approach (local, composite, admixture, or predictive provenancing). Local provenancing focuses on seed collections in close proximity to the restoration site to maximize local adaptation and minimize outbreeding depression (Broadhurst et al., 2008; Breed et al., 2013; Bucharova et al., 2019). In composite provenancing, seeds are sourced across a region from local, intermediate, and more distant populations according to a species' natural gene flow patterns (Broadhurst et al., 2008; Breed et al., 2013). With admixture provenancing, seeds are sourced from populations across a region and environmental conditions without regard to restoration location or a species' gene flow (Breed et al., 2013). With predictive provenancing, seeds are locally sourced as well as collected from areas that are similar to projected climate conditions for the restoration site when such information is available (Breed et al., 2013; Prober et al., 2015; Booth, 2016).

When in doubt, the general recommendation to err on the side of broader rather than narrower collections (Broadhurst et al., 2008) is appropriate for many wetland species. Populations sampled should span a range of local to non-local sources across a region for a "regional admixture provenancing" approach (sensu Bucharova et al., 2019) unless there is strong evidence for outbreeding potential and maladaptation to drive a more conservative local-sourcing approach. On the contrary, many wetlands are in highly altered landscapes with substantial fragmentation, where the available seed may be of poor quality due to inbreeding or genetic drift in remaining remnant wetlands (Broadhurst et al., 2008; Borders et al., 2011; Jordan et al., 2019); thus regional admixture provenancing to increase genetic diversity and phenotypic plasticity in seed mixes would be appropriate especially as a "biological insurance" to extreme and fluctuating environments and to foster adaptive potential in the face of climate change (Hughes and Stachowicz, 2004; Reusch et al., 2005; Broadhurst et al., 2016; Zeldin et al., 2020). These recommendations for regional admixture provenancing are also consistent with the broad dispersal (section "Site and Landscape Context") and gene flow patterns of many avian-dispersed wetland species (Orsenigo et al., 2017; Kettenring et al., 2019b).

Nonetheless, there is a dearth of literature specific to seed sourcing for wetlands species (Figure 2). The emphasis for many terrestrial species has been on developing species-specific seed transfer zones, which identify areas with similar environmental and biotic conditions (i.e., similar ecological distance regardless of geographic distance) within which it is considered acceptable to transfer seeds (Omernik, 1987; Johnson et al., 2004; Miller et al., 2011; Bower et al., 2014); yet this approach places particular emphasis on local adaptation (Broadhurst et al., 2008), which may not be relevant for many wetland species with broad gene flow that can overwhelm local selective pressures. Nonetheless, a large uncertainty that must be addressed to improve decisionmaking is whether sourcing seeds from geographically distant populations impacts the ecological communities dependent on foundational wetland plants (Figure 2; Whitham et al., 2003; Wimp et al., 2004; Bangert et al., 2013; Breed et al., 2018).

\section{Number and choice of individuals}

Collecting broadly across a wetland from numerous individuals will maximize genetic diversity and avoid biasing collections to only the most robust plants growing under pristine conditions or those that are easiest to access (ENSCONET, 2009; Basey et al., 2015; Espeland et al., 2017). Plants that are small, growing in marginal habitats, or in competition with invaders, may possess important adaptations critical for survival in harsh restoration and future climate change conditions (Figure 4; Leger, 2008; Basey et al., 2015).

Guidelines for wetland plants are lacking but for terrestrial species protocols suggest targeting $>50-200$ individuals per population and focusing on large populations likely to harbor more genetic diversity (Lippitt et al., 1994; Broadhurst et al., 2008; ENSCONET, 2009; Basey et al., 2015; Espeland et al., 2017; Bureau of Land Management, 2018); evaluation of these guidelines for wetlands is sorely needed (Figure 2). More patches and populations should be sampled for clonal or self-pollinating species; these species are more likely to have patches with fewer clones and more closely related individuals and populations with more inbreeding and less genetic diversity (Vander Mijnsbrugge et al., 2010; Basey et al., 2015; Bureau of Land Management, 2018; 


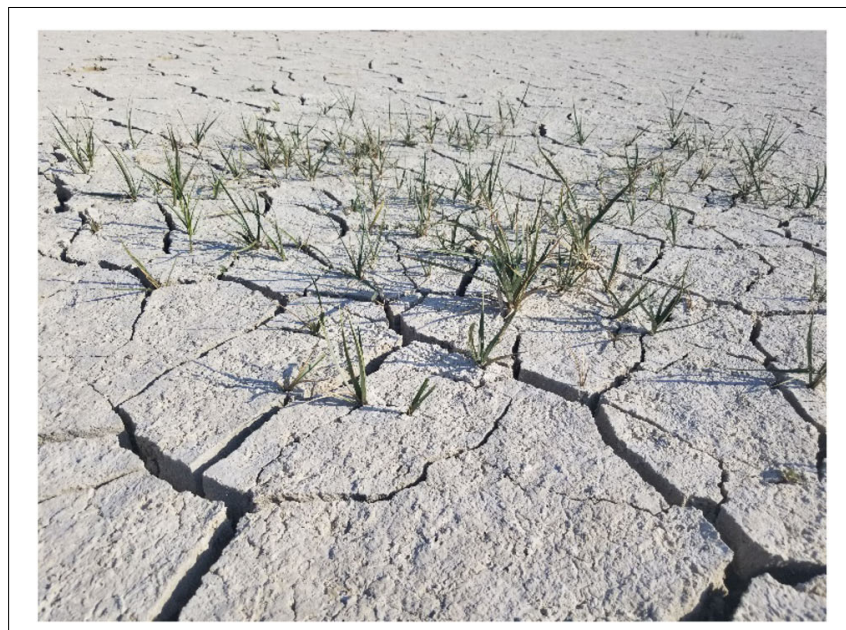

FIGURE 4 | "Ugly" sites, such as sites that are very dry or surrounded by invasive species, should not be over looked when collecting seeds for wetland restoration (Leger, 2008; Basey et al., 2015). Native species growing in these areas may harbor unique genotypes that allow them to survive in harsh conditions. These genotypes may be important if conditions are not ideal at a restoration site in current or future years.

Kettenring et al., 2019b). A reduced number of individuals, such as $>10$, may be all that is necessary for shrubs and trees of riparian, bottomland hardwood, and swamp forests (Allen et al., 2001).

Again relying on guidelines for terrestrial systems (in the absence of wetland-specific protocols), it is recommended to collect no more than approximately $5-20 \%$ of the seed produced in a particular year across a wetland to avoid impacting donor sites, and to avoid collecting multiple years in a row (Menges et al., 2004; ENSCONET, 2009; Vander Mijnsbrugge et al., 2010; Meissen et al., 2015; Bureau of Land Management, 2018; Pedrini and Dixon, 2020). These guidelines are especially significant when plant populations may already be stressed due to factors like weather extremes, excess herbivory, or competition from aggressive invaders (Basey et al., 2015).

The risk of impacting wild populations through overharvesting increases substantially with the increasing global demand for native seed for restoration (Broadhurst et al., 2008; Merritt and Dixon, 2011; Nevill et al., 2018). Nonetheless it is unclear how much these principles and recommendations apply to wetland plants (Figure 2). Many foundational wetland plants are perennial species where annual seed input may play a minor role in population dynamics in a particular year, yet building up a seed bank may be crucial for populations to recover from disturbances like herbivory and drawdowns (Shipley et al., 1989; Boutin and Keddy, 1993; Bornette et al., 2008; Broadhurst et al., 2008; Friess et al., 2012). A fundamental research need is to determine the effects of seed harvesting particularly for wetland plant populations whose dynamics differ from terrestrial plant populations where recommendations are not necessarily transferrable (Figure 2; Boutin and Keddy, 1993; Lamont et al., 2001; Santamaría, 2002; Menges et al., 2004; Silvertown, 2008; Sosnová et al., 2010; Meissen et al., 2015, 2017).

\section{Seed Collection Timing}

Seed ripening for a particular wetland species can vary broadly across a region, and even within a patch and inflorescence, due to weather patterns, environmental variation, and the genetics of the maternal plant (ENSCONET, 2009; Perillo, 2009; Merritt and Dixon, 2011). Seed quantity and quality can also vary across these factors, along with year-to-year variations, so an assessment of seed viability is critical to ensure that sufficient numbers of viable seeds are collected (Lippitt et al., 1994; Haidet and Olwell, 2015; Broadhurst et al., 2016). For most species, collection dates should span multiple weeks while not biasing collections toward early or later-maturing plants (even revisiting the same patch and individual plants again). If possible, collection should also occur over multiple years with varying weather (e.g., wet year and drought year) to ensure sampling of the full range of genetic diversity for a species while not over-harvesting a particular site.

In some cases with submerged aquatic vegetation (SAV) species, it may be possible to harvest photosynthetic reproductive material containing multiple stages of seed maturity, and immature seeds can mature with proper storage conditions after collection (Ailstock et al., 2010). In general, though, seeds should be collected when completely ripe (Figure 5A). For many species, ripening occurs when seeds shift from green to brown but there are notable exceptions, including some bottomland hardwood species that are yellow at maturity, and bird-dispersed seeds that turn bright colors like red (Allen et al., 2001; ENSCONET, 2009; Baskin and Baskin, 2014). The best strategy is to collect during the natural seed (or seedling, in the case of viviparous mangroves and seagrasses) dispersal window and to revisit sites multiple times over a few weeks (Cronk and Fennessy, 2001; Baskin and Baskin, 2014; Basey et al., 2015). Immature seeds (i.e., not fully developed) that will not complete maturity under storage conditions (in contrast to morphologically dormant species; section "Overcoming Seed Dormancy") will have reduced viability and performance in a restoration (Baskin and Baskin, 2014; Basey et al., 2015). Ripe seeds for many emergent and wet meadow species shatter easily from the seed head when touched. Collecting after most seeds have dispersed will result in poor seed lot quality, i.e., low viability (Baskin and Baskin, 2014). For wetland oak trees (Quercus L. species), the acorn separates easily from the cup at maturity (Allen et al., 2001). For submerged aquatic vegetation, cues for seed collecting may be unclear because for many aquatic species, seeds sink when ripe while others float to the water surface (Cronk and Fennessy, 2001).

\section{Seed Collection Approaches}

Clipping seed heads into a bag or netting, or whacking seed heads with a racquet into a large collection container, are two low-tech means for collecting seeds (Figure 5C). A modified portable vacuum can also be used, especially for collecting smaller seeds (Lippitt et al., 1994; Jensen, 2004b; ENSCONET, 2009). In some cases, manual harvesting of SAV can yield large numbers of seed (e.g., of upper third of photosynthetic reproductive stems of Potamogeton perfoliatus L. and Ruppia maritima L.; Ailstock et al., 2010), but more creative solutions are often required such as using a barge-mounted commercial harvester or smaller bowmounted, mechanized harvester (e.g., with Zostera marina L.; 
A



C

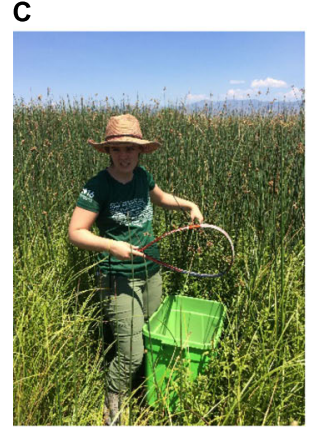

D

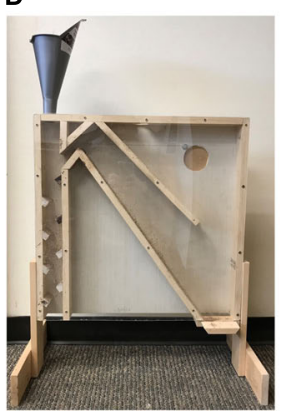

B


$\mathbf{F}$

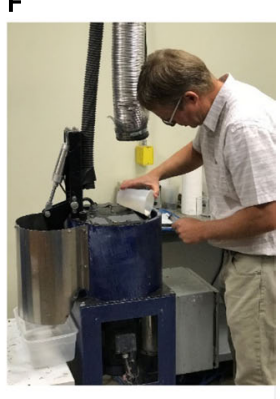

FIGURE 5 | (A) Mature seed of three-square bulrush (Schoenoplectus americanus (Pers.) Volkart ex Schinz \& R. Keller) ready for harvesting; (B) seed sorting based on gravity and sieve size; (C) seed collecting of hardstem bulrush (Schoenoplectus acutus) with a tennis racquet; (D) air column separator for seed cleaning; (E) wetland seeds in cold, moist stratification in a refrigerator; and (F) Dr. Matt Madsen coating wetland seeds with a surfactant seed coating (diatomaceous earth, Selvol $^{\text {TM }}$ polyvinyl alcohol binder, and Aquatrols TM SET 4001 surfactant) in his lab at Brigham Young University, Provo, Utah, United States. The coating is intended to improve germination of seeds under reduced soil moisture conditions.

Marion and Orth, 2010). For trees, ground collection is possible along with using pruning poles or climbing trees to reach seeds prior to their release (Allen et al., 2001).

It is imperative to keep detailed information on dates of collections, site location and conditions, collector, number of plants sampled over a specified area, and observations on seed quality and seed maturation status (Lippitt et al., 1994; Allen et al., 2001; Basey et al., 2015; Kildisheva et al., 2020; Pedrini and Dixon, 2020). Collecting a voucher specimen for species confirmation is a best practice to avoid later confusion (see ENSCONET, 2009; Bureau of Land Management, 2018; Pedrini and Dixon, 2020 protocols for more detail).

\section{SEED PREPARATION}

Best practices for cleaning and storing acquired seed are required to maintain a genetically diverse seed lot (sections "Cleaning Seeds" and "Seed Storage") while viability testing of those seeds ensures that appropriate sowing density rates are applied to the restoration (section "Seed Testing"). To maximize the establishment and survival of seedings, seed enhancements may prove invaluable (section "Seed Enhancements").

\section{Cleaning Seeds}

Seeds of wetland species often have structures that facilitate seed dispersal, such as perigynia, fleshy fruit, and dispersal appendages (Cronk and Fennessy, 2001), but these structures can complicate restoration. Seed cleaning can remove these structures, along with seed coats, chaff, leaves, twigs, insects, dirt, and other non-seed debris. This process is critical for reducing the volume of material that needs to be stored for seeding, isolating seeds for uniformity in sowing, and potentially for enhancing germination (Lippitt et al., 1994; Barton et al., 2016).

The process of seed cleaning is as simple as manually passing seed through a series of sieves with increasingly smaller holes, using an air separator that fractionates out different components by weight using varying airflow (e.g., chaff and non-viable seeds may be lighter than viable seeds), or suspending SAV seeds in water so the viable seeds sink to the bottom (Figures 5B,D; Lippitt et al., 1994; Marion and Orth, 2010). More intensive techniques such as using meat grinders or hammermills can also simultaneously scarify seeds of species that require this type of treatment for physiological or physical dormancy break (section "Overcoming Seed Dormancy"; Lippitt et al., 1994). Fleshyfruited seeds, although not very common in wetland plants, may require special treatment with a rock tumbler or a blender (Thomas, 2003; Dreesen, 2004).

The seed cleaning technique should be chosen carefully so that seeds are not inadvertently damaged (Lippitt et al., 1994). In addition, to maintain a genetically diverse seed lot, it is essential to not lose excessive seeds or to selectively lose certain seeds (i.e., potentially important genetic diversity) during seed cleaning (Basey et al., 2015). It may be necessary to clean seed of the same species in separate batches if different seed sources vary in seed 
weight, and to adjust seed cleaning equipment settings for every batch to minimize loss of healthy seed.

\section{Seed Storage}

In wetland soil seed banks in the field, seeds naturally lose their viability over time due to declining energy resources (endosperm), unfavorable environmental conditions such as desiccation or highly fluctuating temperatures and moisture (which is becoming more extreme due to climate change), wetland drainage due to human activity, seed predation, and microbial degradation (Leck and Brock, 2000; Walck et al., 2011; Long et al., 2015; Carta, 2016; Poschlod and Rosbakh, 2018). Understanding factors driving seed longevity (i.e., seed survival once mature; Long et al., 2015) is crucial to maintain proper seed storage conditions (Bourgeois et al., 2019). Seeds of many species can handle desiccation and store well at low humidity conditions (i.e., orthodox seeds), while others, such as many species of SAV, are desiccation intolerant (i.e., recalcitrant; Hay and Probert, 2013; Bourgeois et al., 2019). Identifying the optimal storage conditions for target species is essential because improper storage can result in loss of a critical component of the genetic diversity of a seed collection or loss of viability in the entire seed lot (Hay and Probert, 2013; Basey et al., 2015; De Vitis et al., 2020). Even under optimal conditions, species will vary widely in their longevity ( $<1$ year up to decades), so minimizing storage time to a few months or less is preferred, although not necessarily logistically feasible with uncertain and variable demands for seed needs (Basey et al., 2015; Barton et al., 2016; Bourgeois et al., 2019; Hancock et al., 2020).

The majority of plants, including wetland species, have orthodox seeds (Leck and Brock, 2000; Hay and Probert, 2013; Bourgeois et al., 2019). Shortly after collection of orthodox seeds, seeds should be stored cool and dry in breathable bags made of cloth or paper to maximize airflow and minimize mold growth (Rieger et al., 2014; Bureau of Land Management, 2018). Storage areas should be maintained free of rodents, birds, and insects to avoid seed predation (Lippitt et al., 1994). Longerterm storage in a walk-in cooler with consistently low humidity and cool temperatures $\left(\sim 4^{\circ} \mathrm{C}\right)$ provides proper conditions for many species (Lippitt et al., 1994). Some bottomland species can be dried to $5-10 \%$ moisture content and stored below freezing ( -1 to $18^{\circ} \mathrm{C}$; Allen et al., 2001). Species that have physiological seed dormancy (section "Overcoming Seed Dormancy") may benefit from storage under moist, cool $\left(\sim 4^{\circ} \mathrm{C}\right)$ conditions to simultaneously break dormancy, and may even maintain viability longer under moist or saturated storage, even if they tolerate desiccation (e.g., Carex L. species and Spartina folisa Trin.; Figure 5E; Budelsky and Galatowitsch, 1999; Sullivan, 2001).

Recalcitrant seeds occur in many wetland plants from wet, mesic, and swamp forests, coastal wetlands, and SAV (Farnsworth, 2000). These species will require storage under high humidity or submerged in water. Studies of SAV species under submerged storage conditions show that seed longevity is higher with aeration (e.g., Zostera marina, Potamogeton perfoliatus), cool temperatures (e.g., Zostera marina, Potamogeton perfoliatus, Ruppia maritima), and high salinity (e.g., Zostera marina, Ruppia maritima; Ailstock et al., 2010; Marion and Orth, 2010;
Baskin and Baskin, 2014). However, some SAV species in the Hydrocharitaceae and Potamogetonaceae families can also be stored under low humidity/low moisture for some temperatures (Kauth and Biber, 2015; Zhao et al., 2017), and thus may not be recalcitrant contrary to general predictions in aquatic plants. Several coastal salt marsh species such as Spartina alterniflora Loisel., even if not strictly recalcitrant, benefit from storage in saline waters (Broome et al., 1988). Storage inconsistencies also arise among bottomland hardwood forest species in the U.S., which as mentioned earlier are mostly orthodox, but many oak species should be maintained with high moisture content $(>30$ 50\%; Allen et al., 2001), along with many other forest wetland species from around the world (Farnsworth, 2000).

\section{Seed Testing}

Seed viability varies widely across years, populations, and wetland species due to factors such as varying environmental conditions (e.g., nutrient availability or water levels), pollen limitation, inbreeding, and insect or pathogen attack (Baskin and Baskin, 2014; Rieger et al., 2014). Therefore, determining the viability of each seed lot is essential. Following seed cleaning, a representative subsample of all seed lots should be assessed to calculate the PLS (pure live seed) percentage (Lippitt et al., 1994). An additional PLS assessment will be required if the seeds are stored for any appreciable length of time (e.g., 10-14 months) or if there were multiple collection periods for the same species from the same location (Lippitt et al., 1994). PLS is equal to \% of pure seed $\times$ viability of the seed $/ 100$. In other words, the PLS identifies what percentage of a seed lot by weight is actually viable seed. The percent purity of the seed accounts for the fact that even after seed cleaning, the seed lot may still have some (hopefully minute) amount of chaff. The viability of the seed is determined through standard tetrazolium testing practices - a viable embryo stains red after soaking in 2, 3, 5-triphenyl tetrazolium chloride (see Miller and Peters, 2010 for detailed protocols).

\section{Seed Enhancements}

Seed enhancements include treatments for breaking seed dormancy, enhancing seed germination, and increasing seedling establishment (Pedrini and Dixon, 2020). Breaking seed dormancy is a well-known requirement for wetland restoration success that has been thoroughly addressed in the literature despite presenting significant restoration logistical challenges (section "Overcoming Seed Dormancy"). The use of seed priming to enhance germination and seed coatings to improve establishment are untested in their potential for improving wetland revegetation (section "Seed Priming and Seed Coatings").

\section{Overcoming Seed Dormancy}

Seed dormancy is an important ecological process that prevents germination when environmental conditions are unsuitable for seedling survival (Baskin and Baskin, 2014; Willis et al., 2014). Seed dormancy can originate from a water impermeable seed coat (i.e., physical dormancy) or internal processes that prevent germination (i.e., physiological dormancy, morphological dormancy, or a combination of the two; Nikolaeva, 1977; 
Baskin and Baskin, 2004, 2014). Physiological seed dormancy is the most common type of dormancy in plants and many species with physiological dormancy cycle between dormant and non-dormant states over growing seasons with the intermediate condition known as conditional dormancy (Baskin and Baskin, 2004, 2014). Conditionally dormant seeds will germinate more slowly and under a narrower range of germination conditions than non-dormant seeds (Baskin and Baskin, 2004, 2014).

Ecologically, seed dormancy can increase ecosystem resilience in wetlands (i.e., the ability of a wetland to recover from a disturbance or regenerate after a drawdown) as dormant seeds are often buried in the soil, thereby promoting the development of a seed bank and maintaining seeds at the site until environmental conditions are more favorable for germination (Schütz and Milberg, 1997; Brock et al., 2003). Furthermore, seed dormancy can be a form of evolutionary bet-hedging that allows for a species' persistence in soil seed banks temporally and spatially (Satterthwaite, 2010; Willis et al., 2014; Long et al., 2015).

Despite its ecological and evolutionary significance, dormancy can be problematic to restoration practice when increasing the speed and uniformity of germination and establishment might be desired (Kettenring and Galatowitsch, 2007a; Espeland et al., 2017; Kildisheva et al., 2020). Determining the type of dormancy present in target restoration species is critical to maximizing native plant community establishment and building up in situ seed banks (Long et al., 2015; Kildisheva et al., 2020).

Dormancy behavior in wetland species is highly varied. Some species do not exhibit any dormancy and are thus able to germinate across the growing season. Examples of species that do not exhibit dormancy include many Juncus L. species (Carta et al., 2013), several seagrass species (e.g., Enhalus Rich. species, Posidonia K.D. Koenig species, Thalassia Banks \& Sol. ex K.D. Koenig species; Orth et al., 2000), and some Salix L. species (Densmore and Zasada, 1983). Other wetland species exhibit moderate to deep levels of physiological dormancy such as Bolboschoenus maritimus (L.) Palla (Marty and Kettenring, 2017), Eleocharis palustris (L.) Roem. \& Schult. (Rosbakh et al., 2019), and Carex species (Schütz, 2000; Kettenring and Galatowitsch, $2007 a, b)$. These species can also vary in dormancy depth across populations and years (Schütz and Rave, 2003; Carta et al., 2016).

Understanding the dormancy characteristics (or lack thereof) of target species can aid in identifying environmental conditions or treatments that break dormancy and promote germination (Lippitt et al., 1994). Dormancy can be broken artificially ex situ if seeding at the start of the growing season. Alternatively, seeds can be sown at the end of the growing season to allow dormancy to break in situ naturally over winter (i.e., "dormant seeding"; Kildisheva et al., 2020). Dormant seeding can assist in building the seed bank or allow annual species (i.e., providing the function of native cover crops; Section "Choosing Native Plants for Functional Goals Including Invasion Resistance") to establish in the first few years as a way to simulate successional processes in wetland restorations. However, a dormant seeding can also result in greater seed loss to predators and less control of location of plant emergence due to secondary dispersal (Lippitt et al., 1994; Kettenring and Galatowitsch, 2011a). There is also some uncertainty about the potential effects of climate change on the cold temperatures required to naturally break seed dormancy in the field, i.e., if there will be sufficiently cold temperatures for the length of time different species require for dormancy break (Walck et al., 2011). When breaking dormancy artificially, doing so for a subset of the seed pool to build up the seed bank can be an effective bet-hedging strategy (Evans and Dennehy, 2005; Basey et al., 2015; Kildisheva et al., 2020). A breakdown of techniques for artificially breaking dormancy are summarized in the following sections.

\section{Scarification}

The first step in germination is the uptake of water into the seed, followed by the activation of metabolic processes and the growth of the embryo (Baskin and Baskin, 2014). Physically dormant seeds have hard seed coats (i.e., hard-seededness; Lippitt et al., 1994) and are unable to imbibe water, thus preventing germination from occurring and keeping the seed in a dormant state (Lippitt et al., 1994; Baskin et al., 2006; Webb et al., 2009). Identifying whether a species exhibits physical dormancy requires reviewing the published literature, expert opinion, inspection of the seed coat, or, in the case where little information is available, recording water uptake by the seeds before and after submerging them in water (Baskin et al., 2006).

Scarification is a method to weaken or puncture the outer seed coat so that water can enter the seed to trigger the process of germination, and can be effective at overcoming both physical and physiological dormancy (Baskin et al., 2006; Kimura and Islam, 2012). There are three main techniques for seed scarification: submersion in a chemical, submersion in boiling water, or mechanical scarification.

Chemical scarification is the process of soaking seeds in a basic solution such as sodium hypochlorite (i.e., bleach) or an acid solution like sulfuric or hydrochloric acid to weaken the seed coat. Chemical scarification is often suitable for seeds that are dispersed by mammals or birds because it mimics weakening of the seed coat by digestive enzymes (Milotić and Hoffmann, 2016). Many wetland species have been found to respond positively to chemical scarification (e.g., genus Bolboschoenus, Eleocharis R. Br., Rhynchospora Vahl, Cladium P. Br., Schoenoplectus; Webb et al., 2009; Wagner and Oplinger, 2017; Rosbakh et al., 2019), though species-specific responses vary [e.g., negative effects seen in Eleocharis ovata (Roth) Roem. \& Schult., Rhynchospora alba (L.) Vahl, Scirpoides holoschoenus (L.) Soják; Rosbakh et al., 2019].

While chemical scarification provides a quick method to break dormancy, it can be risky - if seeds are soaked in the solution for too long the embryo can be destroyed (Lippitt et al., 1994; Baskin et al., 2006). Species-specific experimentation and review of the literature are necessary to prevent over soaking and destruction of the embryo (Rosbakh et al., 2019), though it should be noted that soaking times within a species can vary from year to year and across sites due to inter-annual environmental variation and intraspecific variation in depths of dormancy (Gutterman, 2000; Kettenring, 2016). Additionally, prior to being soaked in acid, seeds should be checked for any penetration of the seed coat that may have occurred during seed cleaning to avoid damage to the embryo (Lippitt et al., 1994). Disposal of the chemical 
solution used to break dormancy can complicate the use of this technique, particularly when scaling up to dormancy break of large quantities of seeds for large-scale revegetation.

Soaking seeds in boiling water, which does not mimic a natural ecological process, can be a safer alternative to chemical scarification. In this method, seeds are submerged in boiling water and remain in the water as it cools (Himanen et al., 2012; Baskin and Baskin, 2014). This process may not be as effective for seeds that have very hard seed coats. However, boiling water is certainly easier to dispose of than bleach or acids and the length of the treatment is less of a concern (Lippitt et al., 1994).

Mechanical scarification involves physically damaging the seed coat and exposing areas in which water can enter the seed. This process mimics natural erosive forces that abrade a seed as it disperses away from the parent plant (e.g., rocks and sand) or digestion by seed dispersers such as waterfowl (Figuerola et al., 2005; Kettenring et al., 2019b). Methods of mechanical scarification vary widely across the scale of seeding and can include agitating seeds and gravel in a cement mixer, gently sanding seeds on a sanding disc, or making a small nick in the seed by hand with a sharp instrument (Lippitt et al., 1994).

\section{Stratification and after-ripening}

In seeds that exhibit physiological dormancy, particularly those from temperate climates, cold, moist stratification is often necessary to break dormancy by mechanically or physically weakening the seed coat. The process of cold, moist stratification mimics over-wintering in low temperatures and moist conditions following seed dispersal at the end of the growing season (i.e., a seasonal, environmental cue; Dietert and Shontz, 1978; Baskin and Baskin, 1989; Willis et al., 2014).

Cold stratification involves placing seeds in filter paper packets, paint strainer bags, or other netting; burying the seeds in a container of substrate; moistening the substrate and (loosely or tightly) sealing the container; then placing the container in a cold room or refrigerator for the appropriate length of time. The temperature and length of stratification time vary widely among species (Baskin and Baskin, 2014; Rosbakh et al., 2019), usually with a minimum of $2-4$ weeks and often 12 or more (Schütz, 2000; Kettenring and Galatowitsch, 2007b; Fernández-Pascual, 2016; Sobze et al., 2019). Temperatures between 0 and $10^{\circ} \mathrm{C}$ are ideal for stratification of many species (Baskin et al., 2006).

Other species with physiological seed dormancy require hot or warm and dry conditions (i.e., after-ripening) or warm, moist conditions (i.e., warm stratification) to break seed dormancy (Tuckett et al., 2010; Baskin and Baskin, 2014, 2020; Carta, 2016). After-ripening and warm stratification often mimic seasonal environmental cues to plants occurring in hot, dry climates where flooding may be short-lived, such as seasonal and temporary wetlands in Mediterranean climates (McLaughlin, 1974; Tuckett et al., 2010; Willis et al., 2014; Carta, 2016).

\section{Other considerations for breaking seed dormancy}

In addition to species-specific dormancy breaking requirements, logistical factors should be weighed when designing a seed dormancy release plan. For example, chemical scarification or cold, moist stratification can work equally well for some species.
Alkali bulrush (Bolboschoenus maritimus) has been found to undergo dormancy break and attain optimal germination after 180 days of cold, moist stratification or after $24 \mathrm{~h}$ of soaking in a 3\% bleach solution (Kettenring, 2016; Marty and Kettenring, 2017). Furthermore, many wetland species that exhibit both physical and physiological dormancy have increased germination rates when subjected to both a bleach treatment followed by cold, moist stratification (Wagner and Oplinger, 2017; Rosbakh et al., 2019). Thus, the choice of dormancy breaking treatment will depend on restoration goals, the available supplies and equipment, and the time available prior to a restoration project.

\section{Seed Priming and Seed Coatings}

In addition to breaking dormancy, seed enhancement treatments can improve germination of sown species in the field. Seed priming, or the "controlled hydration of seeds that is stopped prior to the onset of irreversible germination," is one example of a seed enhancement technology that has been found to promote faster and more synchronous germination (Pedrini and Dixon, 2020). Seed priming can also increase competitive ability due to earlier emergence, increased seed longevity, and increased species' tolerance to stressful environmental conditions (Bradford, 1986; Probert et al., 1991; Hardegree and Van Vactor, 2000; Anwar et al., 2012; Farooq et al., 2013). Priming is often done in osmotic solutions (e.g., solutions containing polyethylene glycol MW 6000-8000), which induces seed stress that prevents germination but allows the seed to imbibe water (Lippitt et al., 1994). In a tidal marsh restoration study, for instance, priming seeds of Suaeda salsa Pall. (Chenopodiaceae) in various solutions containing potassium and nitrate increased seedling growth in high salinity conditions (Song et al., 2012). Studies on priming of other wetland species are limited (Figure 2).

In addition to seed priming to enhance germination, seed coatings are also a promising research frontier in seed-based wetland restoration. Seed pellets, or the addition of filler materials to increase seed size and weight, are one such seed enhancement technology that may improve germination and establishment of wetland species in the field. Seed pellets originated in agriculture, but have more recently been applied in terrestrial restoration (Figure 5F; Madsen et al., 2016a,b; Gornish et al., 2019). Although there is little research on the effectiveness of these pellets in wetland ecosystems, they have the potential to minimize seed loss due to seed buoyancy or wave action and improve germination of low-vigor seeds by incorporating materials such as plant growth regulators into the pellet filler material (Tilley and Hoag, 2006). For example, in inland or tidal wetland systems, pelletized seeds increased germination rates by minimizing seed movement (Tilley and Hoag, 2006).

\section{SITE PREPARATION}

Establishment of native plants via seed requires creating and maintaining "safe sites," i.e., small areas around a seed that have favorable conditions for germination and establishment (Figure 6A; Harper et al., 1965; Harper, 1977; Jordan and Hartman, 1995; Kettenring and Galatowitsch, 2011a). 

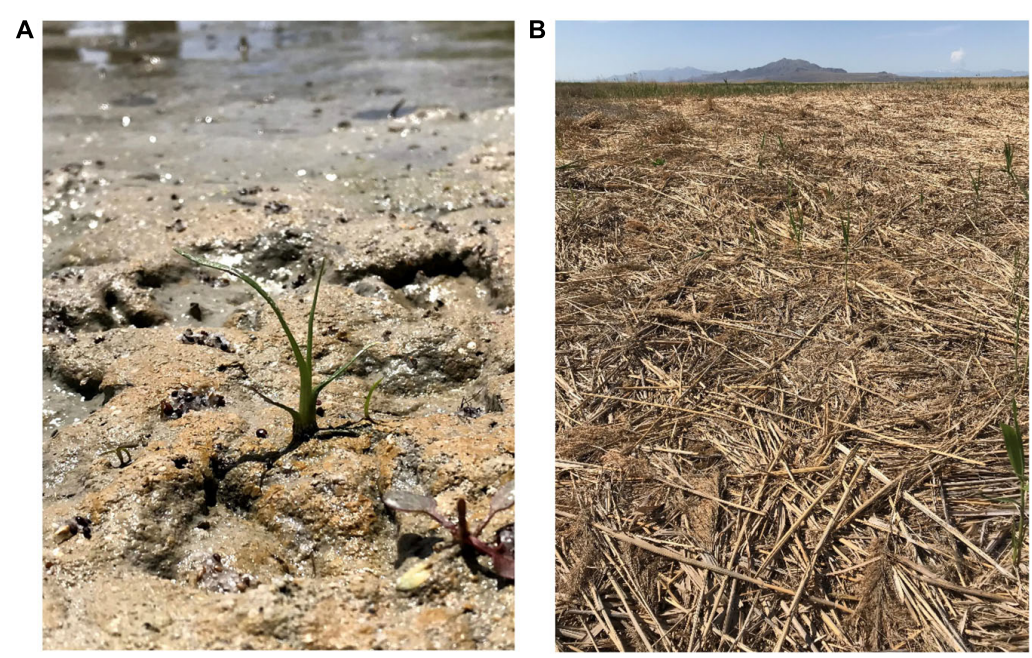

FIGURE 6 | (A) An example of a safe site, in this case for cattail (Typha L. spp.) seed germination, which includes high light and moist soils. (B) Through appropriate site preparation, it is important to address constraints to seeds and seedlings such as unwanted legacy effects. Here, a thick litter layer remains after invasive Phragmites control treatments. This legacy effect likely limits native seed germination and managers need to utilize techniques to remove this litter prior to hydroseeding.

Appropriate site preparation is necessary for safe site creation. Because germination and establishment represent the most vulnerable stage of a plant's life-cycle (James et al., 2011; BarrettLennard et al., 2016), constraints such as herbivory (Dormann et al., 2000; van der Wal et al., 2000; Allen et al., 2001; Haramis and Kearns, 2007) that could potentially limit plant development during these early stages should be minimized prior to restoration actions.

Here we address several considerations for preparing a wetland for revegetation. Prior to these actions, appropriate site manipulations are imperative, such as surface contouring and excavation of sites to expose seed banks; removal of subsurface drainage tiles and plugging of drainage ditches to restore hydrology; management of invasive species to alleviate biotic pressures; improving soil conditions through additions of topsoil, organic matter, mulch, lime (to raise $\mathrm{pH}$ ), fertilizers (if nutrient impoverished), and carbon (if nutrient enriched); inoculation with soil microbes; and soil ripping, disking, or tilling to overcome soil compaction (Galatowitsch and van der Valk, 1994; Vivian-Smith and Handel, 1996; Boyer and Zedler, 1998; Allen et al., 2001; Holguin et al., 2001; Anderson and Cowell, 2004; Perry et al., 2004; Daniels et al., 2005; Sutton-Grier et al., 2009; Larson et al., 2019; Scott et al., 2020). We focus here on the next steps following site manipulation: removal of invasive species legacies (section "Unwanted Legacy Effects From Invasive Species"), plant hydrologic needs (section "Hydrologic Considerations for Seeds and Seedlings"), and the importance of microtopography (section "Microtopography").

\section{Unwanted Legacy Effects From Invasive Species}

If a restoration site has previously been occupied by invasive species, there are likely legacies that constrain native plant establishment long after invasive species have been removed (D'Antonio and Meyerson, 2002; Holdredge and Bertness, 2011; Corbin and D'Antonio, 2012). These legacies can alter soil chemical properties such as salinity (Vivrette and Muller, 1977) and nutrient cycling (Ehrenfeld, 2003; Liao et al., 2008) as well as biotic characteristics like hybridization with native species (Daehler and Strong, 1996), alteration of soil microbial communities (Pringle et al., 2009; Yarwood et al., 2016), depletion of native seed banks (section "Site and Landscape Context"), and physical suppression and shading of native species (Smits et al., 1990; Holdredge and Bertness, 2011). For instance, many wetland invaders leave behind dense litter that insulates temperatures and reduces light availability at the soil surface, thus inhibiting native seed germination and perpetuating the invasion cycle (Figure 6B; Facelli and Pickett, 1991; Kaproth et al., 2013; Farrer and Goldberg, 2014). In another example, after Phragmites australis (Cav.) Trin. ex Steud. control, nitrogen pools can increase for 13 years (Meyerson et al., 1999; Findlay et al., 2003), which can make the site susceptible to future invasion (Burke and Grime, 1996). Furthermore, as many wetland restoration sites occur in areas with a history of intensive anthropogenic land use (e.g., agricultural fields) that perpetuate invasions, altered microbial communities and fertilizer legacies (i.e., increased nitrogen and phosphorus) in the soil can limit the success of invader control and native plant recovery (Peralta et al., 2010; Ardón et al., 2017).

Microbial communities may be able to be restored with effective management of invasive species dominance (Peralta et al., 2017) or hydrologic connectivity that can inoculate the site with diverse soil microbes (Peralta et al., 2010). Legacy effects on microbial communities that arise from invasive species dominance may be linked to time since invasion; thus, prioritizing restoration to areas more recently invaded (i.e., less alteration of microbial communities) could result in better restoration outcomes (Keyport et al., 2019). When considering 
past land use history and the surrounding landscape that contributed to invasions, fertilizer effects can potentially be mitigated with hydrologic flooding (Ardón et al., 2017) and high nutrient inputs may be partially addressed (for the short-term at enormous costs) by including soil amendments (e.g., sawdust, sugar, or alum) during seeding (Perry et al., 2004; Iannone and Galatowitsch, 2008). Alteration of salinity at the site can be addressed with hydrologic flooding, strategic seed sowing timing (section "Optimal Germination Safe Sites and Season"), and selection of species that are able to tolerate higher salinities while providing valuable ecosystem functions (Howard, 2010). Physical suppression and shading of native species should be addressed by removing undesirable vegetation and litter from the site prior to seeding (Lishawa et al., 2019).

Ultimately, there is no standard prescription when it comes to addressing legacy effects at a site and most, if not all, wetland restoration sites are impacted by complex and compounding legacies. Thus, more research is needed to determine how these legacies (and their interactions) influence the recruitment of native wetland plants via seed (Figure 2). Follow-up monitoring and tracking of wetland restoration sites should extend beyond the typical requirements for mandated monitoring in order to accurately assess legacy effects on the appropriate time-scale (section "Monitoring”; Ardón et al., 2010; Peralta et al., 2017).

\section{Hydrologic Considerations for Seeds and Seedlings}

Hydrology is a defining feature of wetland ecosystems and has an overriding influence on the germination and establishment of native plants, as well as the structure and function of wetlands (Weiher and Keddy, 1995; Cronk and Fennessy, 2001; Doherty et al., 2014; Moor et al., 2017; Daniel et al., 2019; Rosbakh et al., 2020). The hydrology of many wetland systems has been altered via methods such as tile drainage, disconnection of floodplain wetlands through channelization, fragmentation, and increased demands upstream for agriculture and urbanization that reduce inputs to wetland systems (Galatowitsch and van der Valk, 1994; Turner and Lewis, 1996; López-Merino et al., 2011; Downard et al., 2014; Donnelly et al., 2020). Further shifts are occurring with climate change-induced precipitation alterations and increased evaporation rates that affect soil moisture (Walck et al., 2011).

These hydrologic alterations can have vast implications for native plant community recovery. Natural hydrologic fluctuations promote native communities that have life history and morphological adaptations to those conditions (Grewell et al., 2013; Doherty et al., 2014; Ruhi et al., 2019), while wetland systems with stabilized hydrology and minimal fluctuations or altered natural disturbance regimes tend to be dominated by invasive species, such as invasive Typha (Typha angustifolia L. and Typha × glauca Godr.; Frieswyk et al., 2007). Hydrologic restoration of wetlands alone is usually not sufficient for returning desired native plant communities (Aronson and Galatowitsch, 2008; Doherty et al., 2014; Toth, 2017).

Given that hydrology is a driver of wetland plant communities, it is critical to consider hydrologic conditions of a site not just prior to and during seeding, but far beyond initial restoration (Budelsky and Galatowitsch, 2000). Hydrologic factors to consider prior to seeding are frequency of flooding, duration of flooding, timing and seasonality of flooding, and depth of flooding (Casanova and Brock, 2000; Perillo, 2009; Webb et al., 2012; Mitsch and Gosselink, 2015). Many wetland seedlings are particularly vulnerable to standing water and the associated declining light levels with water depths and the low (or no) oxygen conditions that can occur (i.e., hypoxia or anoxia; Fraser and Karnezis, 2005; Mitsch and Gosselink, 2015; Rosbakh et al., 2020). Increasing depth, duration, and frequency of inundation generally results in decreased establishment, growth, and plant community diversity (Casanova and Brock, 2000; Webb et al., 2012; Shoemaker and Ervin, 2020). The ideal hydrologic conditions for target native species should be maintained at the site during and at least 1 year after restoration to minimize mortality (Budelsky and Galatowitsch, 2000; Rosbakh et al., 2020).

Many wetland species are well adapted to survive under dynamic hydrology as germination phenology often aligns with hydrological drawdowns or is confined to wetland zones that do not have standing water (Ignacio Galinato and van der Valk, 1986; Merendino et al., 1990; Middleton, 2000). Some species found in seasonal wetlands require flooding to trigger germination (Carta et al., 2013) while others that occur in deep water wetland habitats may not require flooding but instead have a broad hydrologic germination niche (Rosbakh et al., 2020). Regardless of species, some water is necessary for germination, and conditions that are too dry will inhibit germination and establishment of many species. This sensitivity during the early stages of plant development highlights the fact that if the hydrology is not ideal, there is likely to be high seedling mortality.

The hydrologic threshold above which wetland species germinate is species-specific; some species, such as swamp chestnut oak, Quercus michauxii Nutt., may perform better in drier conditions whereas others, such as overcup oak, Quercus lyrata Walt. (Pierce and King, 2007) require saturated soils to germinate. In another example, vascular plants from bogs differed in water-level germination preference $(0 \mathrm{~cm}$ at soil surface vs. $10 \mathrm{~cm}$ below surface) (Landry et al., 2012) while flooding was required for Tillaea vaillantii Willd. (Carta et al., 2013). Some species will perform well when flooded conditions are maintained throughout the restoration process (Coops and van der Velde, 1995; Casanova and Brock, 2000). Achieving and maintaining the appropriate hydrologic conditions is difficult and may be particularly challenging in wetland systems that have unpredictable hydrologic regimes, extensive watershed-level hydrologic alterations, or limited control of water that enters and exits the wetland.

The following steps should be taken for the many species that require non-flooded or shallowly flooded conditions for germination: (1) during seeding, water levels should be drawn down so that the soil is moist and exposed or barely flooded; (2) soil should remain waterlogged post-seeding and during germination and establishment to provide optimal growing conditions; and (3) in the first growing season following establishment, flooding events should be infrequent or short in 
A

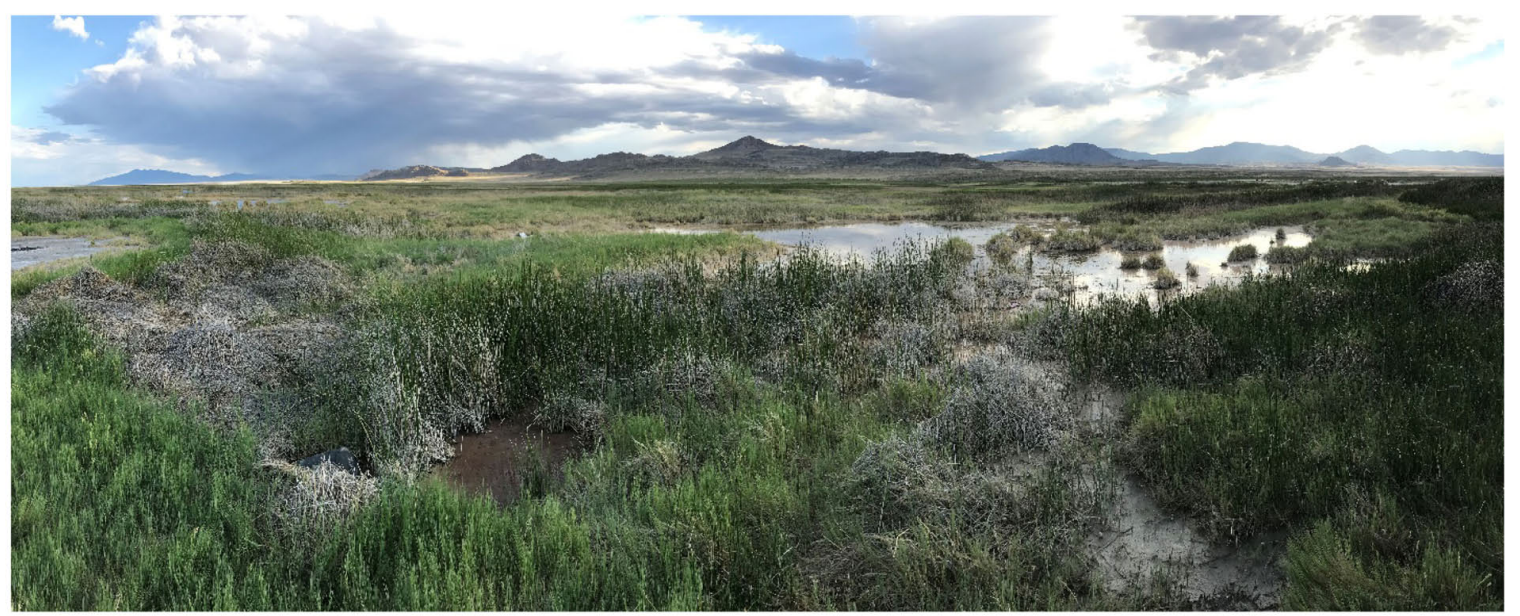

B

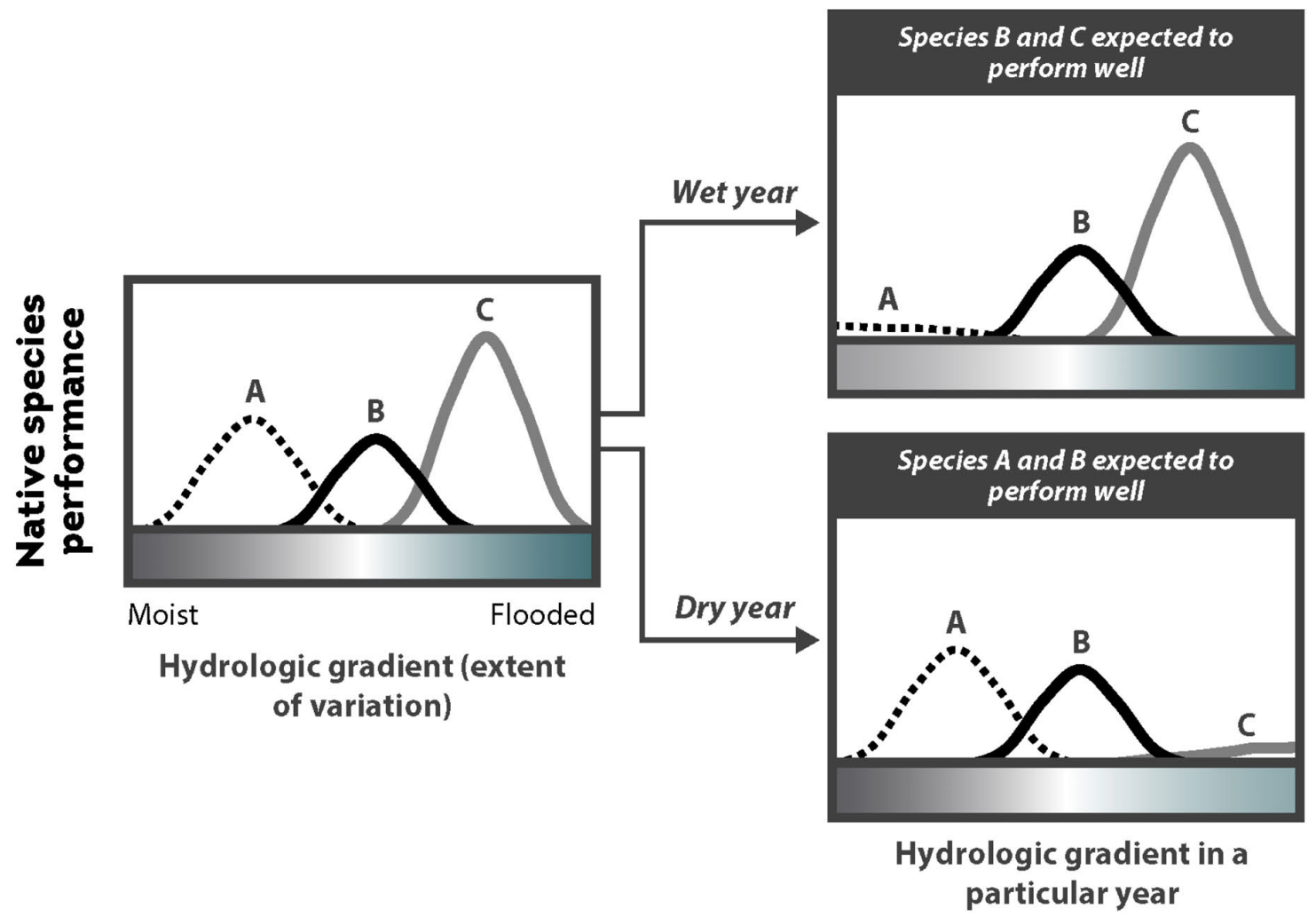

FIGURE 7 | (A) Wetlands are highly dynamic year-to-year and between years, such as in this desert wetland on the border of Utah and Nevada, United States (Salt Springs Waterfowl Management Area); and (B) the location and availability of safe sites for a particular species may vary, therefore, in a wetland due to the amount of water availability in a wet year vs. dry year. Thus, restoration practitioners often choose to sow a seed mix across a site and include a variety of species with different flooding and drought tolerances as a bet-hedging strategy within sites and between years. Adapted from Larson and Funk (2016), with permission from John Wiley and Sons.

duration (Coops and van der Velde, 1995; Webb et al., 2012; Tilley and St John, 2013; Rosbakh et al., 2020). As these plants mature, they develop adaptive structures (e.g., aerenchyma, deeper roots, shoot stiffness) that enable them to withstand more frequent and longer flooding events, as well as stronger erosive and depositional forces from floods, tides, currents, and waves (Cronk and Fennessy, 2001; Balke et al., 2011; Bouma et al., 2013; Schwarz et al., 2015; Moor et al., 2017; Purcell et al., 2019). When maintaining soil moisture is a challenge, additions like mulch and compost can help maintain suitable conditions for germination and establishment (Sullivan, 2001; O'Brien and Zedler, 2006; Laberge et al., 2015; Isselin-Nondedeu and Gaucherand, 2019). Ultimately, it is essential to understand a restoration site's potential hydroperiod and to choose species 
that will perform well with that hydroperiod. In systems that are highly variable, introducing a diversity of species that germinate and establish over a range of hydrologic conditions can be an effective bet-hedging strategy (Figure 7B).

\section{Microtopography}

Microtopography is small-scale vertical relief that provides a diversity of safe sites for seeds and seedlings (Urbanska, 1997; Peach and Zedler, 2006). Diverse microtopography can protect seedlings by providing areas with varying environmental conditions (i.e., differing temperatures, soil characteristics, redox levels, and water retention abilities) and has been shown to improve plant establishment, survival, and species richness in restorations (Urbanska, 1997; Peach and Zedler, 2006; Fivash et al., 2020; Mossman et al., 2020; Ott et al., 2020). Furthermore, the heterogeneity at a site can result in more complex plant communities and facilitate the development of ecosystem functions (Larkin et al., 2016).

Providing diverse safe sites through microtopography manipulations were found to improve revegetation success in a variety of wetland systems including salt marshes (Varty and Zedler, 2008), forested wetlands (Tweedy and Evans, 2001; Sleeper and Ficklin, 2016), and riparian restorations (Polzin and Rood, 2006). In a freshwater wetland restoration, Moser et al. (2007) found more species diversity and richness in created wetlands that were disked to enhance microtopography prior to restoration relative to non-disked and natural wetlands. Additionally, Peach and Zedler (2006) found that Carex stricta Lam. tussocks that formed at the site were themselves safe sites they provided variation in microtopography and were correlated with an increase in species diversity. Microtopography is also significant in riparian systems, and is critical for seed entrapment after hydrochory (water seed dispersal), which enhances seedling establishment (Nilsson et al., 2010).

Creating microtopography can be relatively straightforward at many sites and involves varying the soil surface by bucketmounding, tire-rutting, disking, or disk-harrowing (Moser et al., 2007). Artificial tussocks or mounds can also be created by hand or with shovels to mimic the function of natural plant tussocks that can facilitate the development of other target species (Peach and Zedler, 2006; Wang et al., 2019). Following the creation of diverse safe sites with microtopography, precision seed delivery (i.e., the ability to effectively control the distribution of sown seeds over a site into optimal safe sites) is important to ensure that the seeds reach these favorable areas to increase restoration success (Chambers and MacMahon, 1994; Merritt and Dixon, 2011; Masarei et al., 2019).

\section{SEEDING}

Careful consideration of how, when, and where seeds are introduced to a site can potentially counteract native plant population bottlenecks. Seeding densities can set a plant population on a trajectory toward dominance over competitors (section "Seeding Densities") while seed sowing approaches ensure that seeds experience appropriate environmental conditions (especially light) and do not float out of the target restoration area (section "Seed Sowing Approaches"). The timing and location of seed sowing can be strategically chosen by practitioners such that seeds reach safe sites, are sown prior to invasive species dominance, and are sown across multiple years to overcome high mortality in a particular year (section "Timing and Location of Seed Sowing").

\section{Seeding Densities}

The density at which to sow native seeds will reflect a balance of restoration goals, budgets, and plant competition and has ecological, genetic, and evolutionary implications (Brown and Fridley, 2003; Burton et al., 2006; van Katwijk et al., 2016; Byun et al., 2020). If the goal of a restoration is to quickly establish plants at the site, particularly for invasion resistance, sowing at a higher-than-recommended density is ideal (Evans and Dennehy, 2005; Burton et al., 2006). Sowing densities that are too low will result in the inability of native plants to preempt resources or occupy the available space, thus leaving room for invasive or other undesirable species to grow (Harper, 1977; Byun et al., 2013). Sowing densities that are too high, however, may result in high competition among natives leading to mortality that could open up space for secondary invasions and result in a waste of seed resources (Burton et al., 2006; Pearson et al., 2016). Ultimately, striking a balance that maximizes native plant establishment while minimizing secondary invasion is critical. If invasive species are not an immediate threat and rapid vegetation establishment is less urgent, sowing at lower densities, which is more cost effective, will likely result in similar plant cover in the following years compared to a high-density sowing (Burton et al., 2006; van der Valk and Baalman, 2018).

Some evidence suggests that facilitation among reintroduced native species in restorations occurs in more stressful wetland environments (e.g., high salinity conditions in salt marshes, mangroves, and seagrass meadows; Figure 2; Bertness and Hacker, 1994; O'Brien and Zedler, 2006; Silliman et al., 2015; Renzi et al., 2019), which again warrants a high native sowing density. Furthermore, higher seeding densities with diverse species assemblages is a form of bet-hedging that increases the likelihood that at least some species will be able to germinate and establish over the range of restoration environmental conditions (van Katwijk et al., 2016) or that a subset of the seeds will persist in the seed bank to germinate when environmental conditions become suitable (Baskin et al., 2004; Evans and Dennehy, 2005). Low sowing densities can result in plant communities that are unable to cross a threshold that allows for a self-sustaining population and positive growth rate (i.e., an allee effect; van Katwijk et al., 2016) while higher seeding densities that increase native species establishment can also decrease post-restoration maintenance costs (Palma and Laurance, 2015; Meli et al., 2018).

Recommendations for seed sowing rates are limited and vary widely across wetland types. Identifying the specific number of plants per square meter in the adult plant community is a good first step in determining PLS seeding rates for a restoration project (Houck, 2009; Rieger et al., 2014). For tidal salt marshes, Broome et al. (1988) suggested sowing $100 \mathrm{PLS} \mathrm{m} \mathrm{m}^{-2}$, while Busch et al. (2010) seeded Zostera marina at 37 PLS $\mathrm{m}^{-2}$. In 
emergent, wet meadow, and riparian restorations in Minnesota, United States, the state recommendations range from 1,200 to 3,000 PLS m $\mathrm{m}^{-2}$ (Minnesota Board of Water \& Soil Resources, 2020). For many wetland grasses, recommended seeding rates range from 215 to 320 PLS $\mathrm{m}^{-2}$ for large-seeded species and 430540 PLS m$~^{-2}$ for small-seeded species, with a doubling of these rates in high priority restoration areas (Hoag et al., 2011). Some studies suggest that this range of densities is too low, particularly in sites with high invasive propagule pressure (Reinhardt Adams and Galatowitsch, 2008). Future research is needed to determine optimal seed sowing densities under a variety of environmental conditions to improve seeding rate recommendations in many wetland systems (Figure 2).

\section{Seed Sowing Approaches}

Seeds naturally disperse across wetlands by water, wind, animals (particularly waterbirds), and gravity (Cronk and Fennessy, 2001; Kleyheeg and van Leeuwen, 2015; Reynolds and Cumming, 2016; Soons et al., 2016, 2017). Current restoration techniques that introduce seeds by hand or with machines are designed to overcome dispersal limitations, but do not necessarily mimic these natural dispersal mechanisms.

There are several approaches for sowing seeds into wetlands, including broadcasting, hydroseeding (Figure 8), drill seeding, and overseeding and the choice of an approach is driven by restoration size, seed buoyancy, and germination requirements. While all of these approaches require good seed-to-soil contact to ensure germination and survival (Landry et al., 2012), each presents different benefits and challenges to seed sowing (Barton et al., 2016; Masarei et al., 2019).

With broadcasting, seeds are spread on the soil surface, often by hand, and sometimes mixed with an inert material such as rice hulls or sand to increase seed distribution uniformity. Hand broadcasting seeds is ideal for smaller restorations and in areas with deeper flooding or unconsolidated substrates where it is not possible to get heavy machinery into the restoration site (Apfelbaum and Haney, 2012). Hand broadcasting has also been used effectively with some SAV species like Zostera marina (Marion and Orth, 2010). Hydroseeding uses a backpack or machine-mounted pressurized, agitated tank connected with a nozzle sprayer to distribute a slurry of seed and water. Tackifiers, mulch (straw, wood fiber, or paper), fertilizer, plant hormones, or herbicides can be included in the slurry to enhance restoration effectiveness (Baldos et al., 2017). In drill seeding, a machine attached to a tractor drills shallow holes (e.g., 3-5 cm) and drops in seed. Drill seeding results in plant placement that is gridded and unnatural in appearance (Allen et al., 2001), while broadcasting and hydroseeding create a more natural-looking restored plant community. In the overseeding method, seed is simply spread over existing vegetation; this method is often ineffective due to seed light requirements of many wetland species (Ignacio Galinato and van der Valk, 1986; Smits et al., 1990; Baskin et al., 2004; Kettenring et al., 2006; Hoag et al., 2011; Carta et al., 2016; Rosbakh et al., 2020) but see (Landry et al., 2012).

Seed buoyancy is an important adaptation for many wetland plants in natural systems to facilitate water seed dispersal, but can be challenging in restorations (Boedeltje et al., 2003; Bohnen and Galatowitsch, 2005; Broek et al., 2005; Nilsson et al., 2010). The intersection of seed buoyancy with the naturally dynamic hydrology of wetlands due to varying water levels, tides, or wave action, presents additional seeding challenges (Cronk and Fennessy, 2001; Sullivan, 2001). An obvious approach to counteract these challenges might be to use drill seeding, a common practice in dryland systems that involves burial to keep seeds in place yet fails for many wetland species given their seed light requirements. However, for bottomland hardwood forest species that do not have these light needs, sowing depths of 5$10 \mathrm{~cm}$ are ideal (Allen et al., 2001). Similarly, some plant species occupying deep-water habitats may also be able to germinate in the dark (Rosbakh et al., 2020).

For many emergent and wet meadow species, the use of a tackifier when hydroseeding, under some circumstances, may effectively bind seeds to the soil surface (Tilley and Hoag, 2006; Baldos et al., 2017; England, 2019). That said, there is likely to be some redistribution of seeds on-site with dynamic water levels especially as tackifier adhesion wears off (Bohnen and Galatowitsch, 2005; Tilley and Hoag, 2006). Hydroseeding with mulch or an organic amendment has also enhanced seedling success in tidal wetlands (Sullivan, 2001). In another approach for keeping seeds in place, sowing seeds of Zostera marina in burlap bags comprised of natural fiber, seed, and sediment has also been found to improve recruitment outcomes in seagrass meadow restoration with high wave action (Unsworth et al., 2019). In tidal wetlands, seeding may be more effective in the upper reaches of
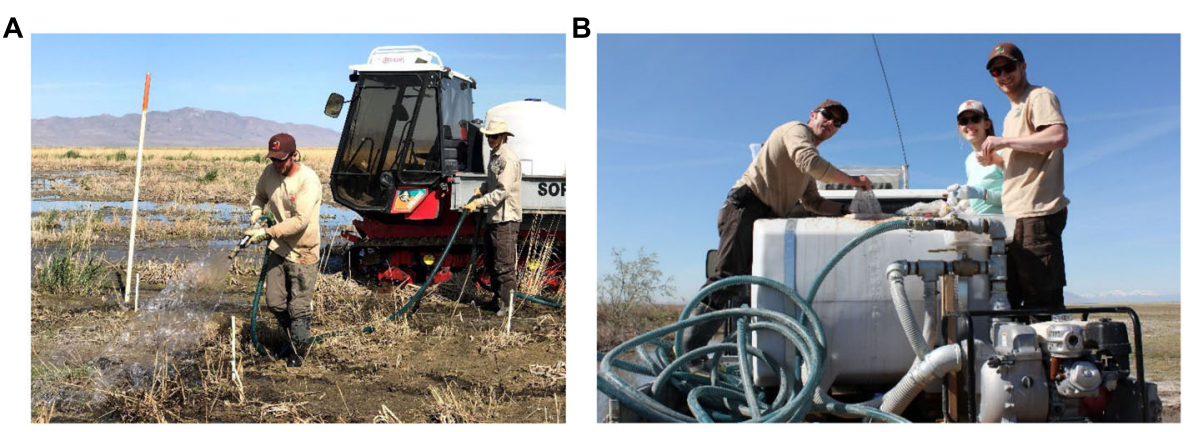

FIGURE 8 | (A) Hydroseeding a Great Salt Lake wetland restoration experiment; and (B) a hydroseeding tank and pump on the back of marsh-capable equipment. 
marshes that are more protected as well as during periods of time when storms are uncommon (Broome et al., 1988).

\section{Timing and Location of Seed Sowing Optimal Germination Safe Sites and Season}

Given the vulnerability of seeds and seedlings to high mortality (James et al., 2011; Barrett-Lennard et al., 2016), it is essential to carefully plan the timing and location of seedings so that site conditions align with seed and seedling needs for germination and establishment (i.e., safe sites). Temperature, light, and moisture are primary drivers of germination and establishment; salinity, $\mathrm{pH}$, alkalinity, and substrate type and texture can also be important (Ignacio Galinato and van der Valk, 1986; Shipley et al., 1989; Shipley and Parent, 1991; Coops and van der Velde, 1995; Mahoney and Rood, 1998; Borkenhagen and Cooper, 2019; Prach et al., 2019; Rosbakh et al., 2020). In wetlands that are geomorphically dynamic (i.e., riparian and floodplain wetlands, salt marshes, estuarine wetlands, mangroves), accretion and erosion dynamics with tides (daily to multi-year cycles), currents, and flooding can also limit seed germination and seedling survival (Giroux and Bédard, 1995; Mahoney and Rood, 1998; Balke et al., 2013; Ge et al., 2019).

The optimal seed sowing time should occur when the target species' germination requirements - which can vary from extremely narrow to quite broad - overlap with field conditions (Donohue et al., 2010; Baskin and Baskin, 2014). However, this timing will become more challenging with climate changedriven shifts in temperature, and will particularly impact species with narrower and cooler temperature germination requirements (Walck et al., 2011; Noe et al., 2019). Germination is triggered for most species when temperatures fluctuate over the course of $24 \mathrm{~h}$ and are within the threshold of optimal temperatures for a particular species (Brändel, 2006; Liu et al., 2013; Baskin and Baskin, 2014; Carta et al., 2016). The range of optimal temperatures necessary to cue germination can range from $0-10^{\circ} \mathrm{C}$ for some seagrass species, such as Zostera marina (Orth and Moore, 1983), to $32-35^{\circ} \mathrm{C}$ for some species, such as Bolboschoenus maritimus and some Schoenoplectus species (Kettenring, 2016; Marty and Kettenring, 2017; Wagner and Oplinger, 2017). More moderate and often fluctuating growing season temperatures are the norm for many species particularly in temperate regions (e.g., Ignacio Galinato and van der Valk, 1986; Leck, 1996; Jensen, 2004a; Kettenring and Galatowitsch, 2007a; Rosbakh et al., 2020). Seeds should be sown as soon as temperatures are within a species' optimal range before the plant canopy has time to develop and inhibit light at the soil surface (Grime et al., 1981; Kettenring et al., 2006). Ensuring light availability can also be addressed through litter removal (section "Unwanted Legacy Effects From Invasive Species).

In saline wetlands, including seagrass ecosystems, determining seed sowing timing should also consider salinity levels at the site. Though well adapted to saline conditions as adults, seedlings in these ecosystems typically need lower salinity levels for optimal establishment (Broome et al., 1988; Saenger and Siddiqi, 1993; Denzler, 2017; Noe et al., 2019). Sowing seeds after periods of rainfall or freshwater flooding, which can occur naturally in some saline wetlands in the early spring, can lower salinity to levels that are more conducive to seedling survival (Zedler et al., 1992; Denzler, 2017; Noe et al., 2019).

In highly geomorphically active wetlands, seeding success will be highest when physical disturbances are minimal (i.e., reduced flooding with exposed, stable sediments in fluvial and tidal ecosystems) for a sufficient period of time for seedling establishment (i.e., the "recruitment box"; Mahoney and Rood, 1998; Balke et al., 2014). Alternatively, interventions to temporally protect vulnerable seedlings from disturbance can potentially improve survival, such as with biodegradable structures (Balke et al., 2013). Despite the promise of these potential manipulations, further research is needed to systematically target recruitment bottlenecks specific to many species and wetland types, which can yield insights into environmental manipulations or species selection that maximizes recruitment (Figure 2; James et al., 2011; Larson and Funk, 2016).

\section{Priority Effects}

In addition to fine-tuning seed sowing to the environmental conditions at a site, manipulating priority effects is another tool to improve native plant community recovery. Priority effects occur when earlier establishing species impact the germination and survival of later arriving species, allowing earlier arriving species to preempt available resources (Figure 9; Grman and Suding, 2010; Hess et al., 2019). Much of the research on priority effects in restoration supports the idea that seeding 1-6 weeks earlier in the season can provide a competitive advantage to seeded species, as they are able to acquire resources needed for germination and establishment before unwanted invaders (Young et al., 2017). However, in reality many invasive species are successful because of their early emergence times, thus there may not necessarily be native species that can preempt invaders by earlier germination (Gioria and Pyšek, 2017). Furthermore, any initial advantage to seeded species may fade over time as stronger competitors take hold (Young et al., 2017). Further research is needed to identify species-specific guidelines on sowing timing in various environmental conditions that may confer a native priority effect (Figure 2).

\section{Multi-Year Seed Sowing}

Because of the considerable year-to-year variation in environmental conditions at a wetland site, variation that will only become more extreme with climate change (Walck et al., 2011; Figure 7A), bet-hedging with multi-year seeding is a useful tool in seed-based restoration to reduce the risk of mortality, to maximize recruitment, and to even facilitate natural succession. Ideally, seeding should occur across multiple years to increase the likelihood that seeds are exposed to optimal germination conditions (e.g., between wet years and dry years; Figure 7B; Groves and Brudvig, 2019). Additionally, seeding over a broader area than what is expected to be suitable for seeds can be a good bet-hedging strategy as it offers diverse safe sites that may be more conducive to germination for some species (Doherty and Zedler, 2015), though this approach must be balanced with logistical and financial constraints. 

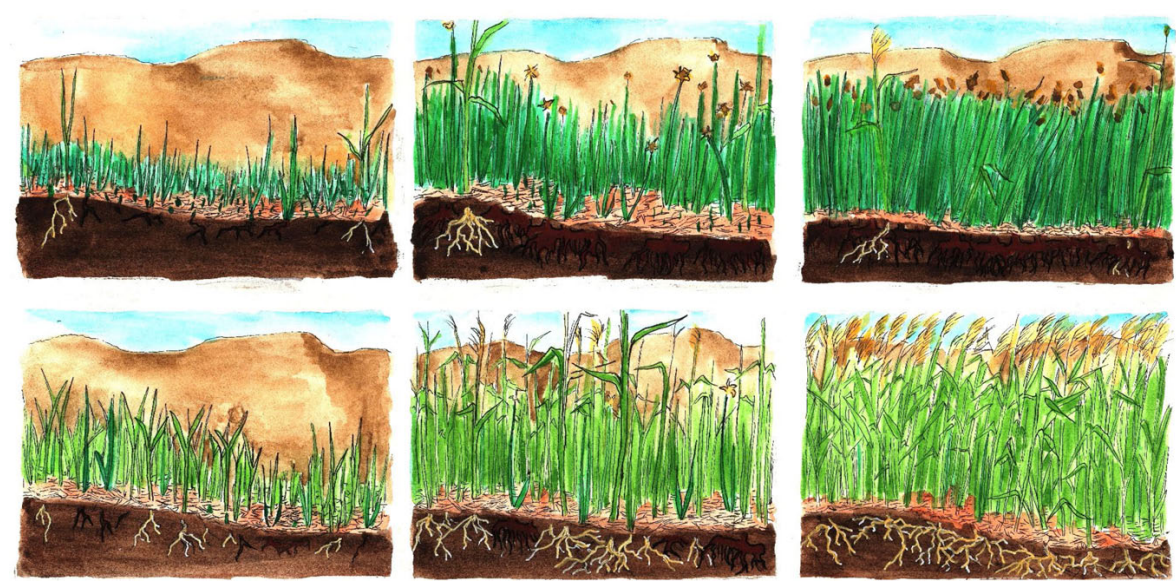

FIGURE 9 | The timing of when native seeds are sown can have a huge influence on plant community outcomes such as when you sow seeds early enough in the growing season to favor the dominance of a native species (in top scenario) vs. dominance of an unwanted invader (in bottom scenario). In the top scenario, non-dormant seeds of native species (here Schoenoplectus americanus, with darker green stems and darker brown roots and rhizomes) were sown early in the growing season to maximize native seedling emergence and plant establishment. Only 1-2 individuals of an invasive species (here Phragmites australis, with lighter green stems and beige roots and rhizomes) emerges; these individuals can be readily managed through spot spraying. In the bottom scenario, abundant $P$. australis seedlings emerge prior to the sowing of the target native species $S$. americanus. Once established, $P$. australis competitively excludes any $S$. americanus seedlings resulting in an invader monoculture. Watercolor by Corey Labrie.

\section{MAINTENANCE AND MONITORING}

A wetland restoration is not complete once the native plant community has established. Invasive species will be a perennial problem that will require vigilance (section "Invader Management"). Long-term monitoring will inform additional interventions that are essential to preserve the restoration investment (section "Monitoring”).

\section{Invader Management}

Many wetland restorations are conducted in response to invasive plants, but even if initial control is successful, most restorations will be subject to reinvasion and secondary invasions by new species because wetlands are so invasion prone (Zedler and Kercher, 2004; Kettenring and Adams, 2011; Pearson et al., 2016; Banks et al., 2018). Also, restoration activities often cause disturbances that create the high resource conditions under which many wetland invaders thrive (e.g., high light, nutrients; Davis et al., 2000; Galatowitsch and Richardson, 2005; Kettenring and Adams, 2011). Thus, control of invaders, both returning and new, should occur early and often while long-term management (e.g., continual spot spraying) will be necessary (e.g., Lombard et al., 2012). If initial native revegetation is effective, the reestablishing plant community should become less invasible as resource availability declines. But during the establishment phase, expect that much of a restoration budget will go toward invasive plant control (Bohnen and Galatowitsch, 2005; Rieger et al., 2014). The most effective approach is to control small and new (re)invasions immediately and with a sustained effort, rather than waiting for an appreciable invasive plant cover to accumulate or a seed bank to develop (Moody and Mack, 1988; Rieger et al., 2014). Specific recommendations on control for wetland invaders is beyond the scope of this review, but there are numerous resources, both general and species-specific, that can be accessed for guidance (e.g., Lavergne and Molofsky, 2006; Apfelbaum and Haney, 2012; Hazelton et al., 2014; Hussner et al., 2017; Bansal et al., 2019).

\section{Monitoring}

Monitoring is important to uncover mechanisms limiting seeding success to inform future projects. Indeed, without detailed, long-term monitoring there would be limited historical evidence about the failure of native vegetation to return to wetland restorations and the need for active revegetation (e.g., Galatowitsch and van der Valk, 1996; Mulhouse and Galatowitsch, 2003; Aronson and Galatowitsch, 2008). The outcomes (e.g., soil and peat development or the establishment of a self-sustaining plant population), underlying drivers (e.g., how legacy effects drive plant survival), and potential set-backs take years, if not decades or centuries, to develop, particularly for long-lived plant species (Ballantine and Schneider, 2009; Godefroid et al., 2011; Drayton and Primack, 2012; McGlathery et al., 2012; Moreno-Mateos et al., 2012; Strobl et al., 2019). Thus, long-term monitoring is essential (Blossey, 1999).

With increased urgency for, but limited successful examples of, seed-based wetland restoration around the globe, intensive monitoring of seed and seedling outcomes is imperative. For example, if monitoring can identify the limiting seed or seedling life stage for restoration, as has been done effectively in dryland restorations (James et al., 2011), additional restoration interventions can be implemented and sites can be chosen more strategically to ensure seed and seedling success (Kotze et al., 2019). The details of developing a monitoring plan are beyond 
the scope of this review but see these excellent resources as examples (Elzinga et al., 1998; Neckles et al., 2002; Perillo, 2009; Apfelbaum and Haney, 2012; Rieger et al., 2014). The ultimate goal is to construct a thoughtful monitoring plan that is feasible and will yield insights to maximize the success of current and future seeding. In turn, sharing the outcomes of revegetation (i.e., monitoring results) with others, formally or informally, is crucial to enable continued learning and improvement of revegetation practices.

\section{CONCLUSION}

Restoration of wetlands has been occurring for decades, if not centuries, but the global importance of wetland restoration is greatly elevated with increasing anthropogenic impacts and climate change (Finlayson et al., 2018). Restoration of lost functions and services remains an elusive goal at a time when the climate mitigation properties of wetlands and their plants are urgently needed (Endter-Wada et al., 2018, 2020; Espeland and Kettenring, 2018; Finlayson et al., 2018). It is paramount to improve the success of seed-based restoration, specifically reestablishing the foundational wetland plants that support critical functions and services (Whitham et al., 2003; Halpern et al., 2007; Renzi et al., 2019). Recent ecological, genetic, and evolutionary scientific breakthroughs, such as determining the effects of plant genetic diversity on ecosystem function and how that valuable diversity may be lost in the restoration process (Reynolds et al., 2012; Kettenring et al., 2014; Basey et al., 2015; Espeland et al., 2017), can and should be harnessed to advance seed-based wetland restoration. Yet, improvements in and successful studies of seed-based wetland restoration lag behind other ecosystems such as forests and drylands (Palma and Laurance, 2015; Kildisheva et al., 2016; Grossnickle and Ivetić, 2017). Perhaps this research gap is due to long-held views that wetland restorations do not require active revegetation (Galatowitsch and van der Valk, 1996; Rohal et al., 2018) or to the logistical challenges of seeding in flooded environments and unconsolidated substrates. However, given the often slow development of long-lived wetland vegetation post-disturbance, and the intense invasion pressure experienced by many wetlands (Boutin and Keddy, 1993; Zedler and Kercher, 2004), the rapid reintroduction of diverse native plant communities is essential.

In this synthesis, we have consolidated ecological, genetic, and evolutionary principles and restoration guidelines for wetlands, but there is still a lot to learn (Figure 2). Gaps in knowledge and untested practices will increase risks for future seed-based wetland restoration. We should expect that going forward, some failure of restorations will be inevitable (Broadhurst et al., 2016), particularly given the demographic bottlenecks that seeds and

\section{REFERENCES}

Aavik, T., Edwards, P. J., Holderegger, R., Graf, R., and Billeter, R. (2012). Genetic consequences of using seed mixtures in restoration: a case study of a wetland plant Lychnis flos-cuculi. Biol. Conserv. 145, 195-204. doi: 10.1016/j.biocon. 2011.11.004 seedlings present to plant populations (Leck et al., 2008; Palma and Laurance, 2015). But we can learn from and manage that risk using strategic long-term and large-scale monitoring to tease apart complicated processes in "messy" datasets (e.g., Dickens et al., 2016; Rinella et al., 2016) and best practices (e.g., using approaches that minimize genetic diversity loss in a restoration seed lot; Espeland et al., 2017). These failures can also be used as a catalyst to renew research efforts to better understand the seed ecology of wetland plants (Broadhurst et al., 2016; Ladouceur et al., 2018). Then, we will be one step closer to restoring wetland functions and services needed for human and ecological communities.

\section{ETHICS STATEMENT}

Written informed consent was obtained from the individuals for the publication of any potentially identifiable images included in this article.

\section{AUTHOR CONTRIBUTIONS}

Both the authors jointly conceived, researched, and wrote the manuscript.

\section{FUNDING}

KK and ET were supported by grants from the Community Foundation of Utah; Ducks Unlimited Canada; the Salt Institute; U.S. Fish \& Wildlife Service; Utah Agricultural Experiment Station; Utah Department of Agriculture and Food; Utah Division of Forestry, Fire \& State Lands; Utah Division of Wildlife Resources; Utah Public Lands Initiative; and Western Integrated Pest Management Center. This is publication number 9145 of the Utah Agricultural Experiment Station. Publication of this article was funded in part by the USU Libraries Open Access Fund and the USU Ecology Center.

\section{ACKNOWLEDGMENTS}

We thank the many wetland managers whose insights informed this document, including David England, Keith Hambrecht, and Chad Cranney. Drs. Christine Rohal and Carrie Reinhardt Adams provided valuable manuscript feedback as did the members of the Wetland Ecology and Restoration Lab at USU and two journal reviewers. We thank Michael Wernert for critical graphic design support and Corey Labrie for the beautiful watercolor paintings.

Ailstock, M. S., Shafer, D. J., and Magoun, A. D. (2010). Protocols for use of Potamogeton perfoliatus and Ruppia maritima seeds in large-scale restoration. Restor. Ecol. 18, 560-573. doi: 10.1111/j.1526-100x.2010.00 696.x

Alexander, L. C., Fritz, K. M., Schofield, K. A., Autrey, B. C., DeMeester, J. E., Golden, H. E., et al. (2018). Featured collection introduction: connectivity of 
streams and wetlands to downstream waters. JAWRA 54, 287-297. doi: 10 . $1111 / 1752-1688.12630$

Allen, J. A., Keeland, B. D., Stanturf, J. A., Clewell, A. F., and Kennedy, H. E. Jr. (2001). A guide to bottomland hardwood restoration. US Geological Survey, Biological Resources Division and US Department of Agriculture, Forest Service, Southern Research Station, Reston, VA. Gen. Tech. Rep. SRS 40:132.

Anderson, C. J., and Cowell, B. C. (2004). Mulching effects on the seasonally flooded zone of west-central Florida, USA wetlands. Wetlands 24, 811-819. doi: 10.1672/0277-5212(2004)024[0811:meotsf]2.0.co;2

Anwar, M. P., Juraimi, A. S., Puteh, A., Selamat, A., Rahman, M. M., and Samedani, B. (2012). Seed priming influences weed competitiveness and productivity of aerobic rice. Acta Agricult.Scand. Sec. B Soil Plant Sci. 62, 499-509.

Apfelbaum, S. I., and Haney, A. W. (2012). Restoring Ecological Health to Your Land. Washington, DC: Island Press.

Ardón, M., Helton, A. M., Scheuerell, M. D., and Bernhardt, E. S. (2017). Fertilizer legacies meet saltwater incursion: challenges and constraints for coastal plain wetland restoration. Elem. Sci. Anth. 5:41. doi: 10.1525/elementa.236

Ardón, M., Montanari, S., Morse, J. L., Doyle, M. W., and Bernhardt, E. S. (2010). Phosphorus export from a restored wetland ecosystem in response to natural and experimental hydrologic fluctuations. J. Geophys. Res. 115:G04031.

Aronson, M. F. J., and Galatowitsch, S. (2008). Long-term vegetation development of restored prairie pothole wetlands. Wetlands 28, 883-895. doi: 10.1672/08142.1

Baldos, O. C., DeFrank, J., and Lukas, S. B. (2017). Evaluation of 3 hydromulch planting techniques for establishing Fimbristylis cymosa (mau'u 'aki'aki), a native Hawaiian coastal sedge with roadside revegetation and landscape ground cover potential. Native Plants J. 18, 20-31. doi: 10.3368/npj.18.1.20

Balke, T., Bouma, T. J., Horstman, E. M., Webb, E. L., Erftemeijer, P. L. A., and Herman, P. M. J. (2011). Windows of opportunity: thresholds to mangrove seedling establishment on tidal flats. Mar. Ecol. Progr. Ser. 440, 1-9. doi: 10.3354/meps09364

Balke, T., Herman, P. M. J., and Bouma, T. J. (2014). Critical transitions in disturbance-driven ecosystems: identifying windows of opportunity for recovery. J. Ecol. 102, 700-708. doi: 10.1111/1365-2745.12241

Balke, T., Webb, E. L., van den Elzen, E., Galli, D., Herman, P. M. J., and Bouma, T. J. (2013). Seedling establishment in a dynamic sedimentary environment: a conceptual framework using mangroves. J. Appl. Ecol. 50, 740-747. doi: 10.1111/1365-2664.12067

Ballantine, K., and Schneider, R. (2009). Fifty-five years of soil development in restored freshwater depressional wetlands. Ecol. Appl. 19, 1467-1480. doi: 10.1890/07-0588.1

Bangert, R., Ferrier, S. M., Evans, L., Kennedy, K., Grady, K. C., Hersc-Green, E., et al. (2013). The proportion of three foundation plant species and their genotypes influence an arthropod community: restoration implications for the endangered southwestern willow flycatcher. Restor. Ecol. 21, 447-456. doi: 10.1111/j.1526-100x.2012.00910.x

Banks, P. B., Byrom, A. E., Pech, R. P., and Dickman, C. R. (2018). Reinvasion is not invasion again. BioScience 68, 792-804. doi: 10.1093/biosci/biy076

Bansal, S., Lishawa, S. C., Newman, S., Tangen, B. A., Wilcox, D., Albert, D., et al. (2019). Typha (Cattail) invasion in North American Wetlands: biology, regional problems, impacts, ecosystem services, and management. Wetlands 39, 645-684. doi: 10.1007/s13157-019-01174-7

Barga, S. C., Olwell, P., Edwards, F., Prescott, L., and Leger, E. A. (2020). Seeds of Success: a conservation and restoration investment in the future of U.S. lands. Conserv. Sci. Pract. 2:e209.

Barrett-Lennard, E. G., Norman, H. C., and Dixon, K. (2016). Improving saltland revegetation through understanding the "recruitment niche": potential lessons for ecological restoration in extreme environments. Restor. Ecol. 24, S91-S97.

Barton, M. L. I, Medel, D., Johnston, K. K., and Whitcraft, C. R. (2016). Seed collection and germination strategies for common wetland and coastal sage scrub species in Southern California. Bull. Southern Calif. Acad. Sci. 115, 41-71. doi: 10.3160/soca-115-01-41-71.1

Basey, A. C., Fant, J. B., and Kramer, A. T. (2015). Producing native plant materials for restoration: 10 rules to collect and maintain genetic diversity. Native Plants J. 16, 37-53. doi: 10.3368/npj.16.1.37
Baskin, C. C., and Baskin, J. M. (1989). "Physiological dormancy and germination in relation to seed bank ecology," in Ecology of Seed Banks, eds M. A. Leck, V. T. Parker, and R. L. Simpson (San Diego, CA: Academic Press Inc), 164-170.

Baskin, C. C., and Baskin, J. M. (2014). Seeds: Ecology, Biogeography, and Evolution of Dormancy and Germination. Second. New York, NY: Elsevier.

Baskin, C. C., and Baskin, J. M. (2020). Breaking seed dormancy during dry storage: a useful tool or major problem for successful restoration via direct seeding? Plants 9:636. doi: 10.3390/plants9050636

Baskin, C. C., Baskin, J. M., and Chester, E. W. (2004). Seed germination ecology of the summer annual Cyperus squarrosus in an unpredictable mudflat habitat. Acta Oecol. 26, 9-14. doi: 10.1016/j.actao.2004.03.001

Baskin, C. C., Thompson, K., and Baskin, J. M. (2006). Mistakes in germination ecology and how to avoid them. Seed Sci. Res. 16, 165-168. doi: 10.1079/ ssr2006247

Baskin, J. M., and Baskin, C. C. (2004). A classification system for seed dormancy. Seed Sci. Res. 14, 1-16. doi: 10.1079/ssr2003150

Benayas, J. M. R., Newton, A. C., Diaz, A., and Bullock, J. M. (2009). Enhancement of biodiversity and ecosystem services by ecological restoration: a meta-analysis. Science 325, 1121-1124. doi: 10.1126/science.1172460

Benson, C. E., Carberry, B., and Langen, T. A. (2019). Public-private partnership wetland restorations provide quality forage for waterfowl in Northern New York. J. Fish Wildl. Manag. 10, 323-335. doi: 10.3996/092018-jfwm-080

Bertness, M. D., and Hacker, S. D. (1994). Physical stress and positive associations among marsh plants. Am. Nat. 144, 363-372. doi: 10.1086/285681

Bischoff, A., Steinger, T., and Müller-Schärer, H. (2010). The importance of plant provenance and genotypic diversity of seed material used for ecological restoration. Restor. Ecol. 18, 338-348. doi: 10.1111/j.1526-100x.2008.00454.x

Blossey, B. (1999). Before, during and after: the need for long-term monitoring in invasive plant species management. Biol. Invas. 1, 301-311.

Blum, M. J., Knapke, E., McLachlan, J. S., Snider, S. B., and Saunders, C. J. (2010). Hybridization between Schoenoplectus sedges across Chesapeake Bay marshes. Conserv. Genet. 11, 1885-1898. doi: 10.1007/s10592-010-0080-1

Boedeltje, G., Bakker, J. P., Bekker, R. M., Van Groenendael, J. M., and Soesbergen, M. (2003). Plant dispersal in a lowland stream in relation to occurrence and three specific life-history traits of the species in the species pool. J. Ecol. 91, 855-866. doi: 10.1046/j.1365-2745.2003.00820.x

Bohnen, J. L., and Galatowitsch, S. M. (2005). Spring Peeper Meadow: revegetation practices in a seasonal wetland restoration in Minnesota. Ecol. Restor. 23, 172-181. doi: 10.3368/er.23.3.172

Booth, T. H. (2016). Identifying particular areas for potential seed collections for restoration plantings under climate change. Ecol. Manag. Restor. 17, 228-234. doi: $10.1111 /$ emr.12219

Borders, B. D., Cypher, B. L., Ritter, N. P., and Kelly, P. A. (2011). The challenge of locating seed sources for restoration in the San Joaquin Valley. California. Nat. Areas J. 31, 190-199. doi: 10.3375/043.031.0213

Borkenhagen, A. K., and Cooper, D. J. (2019). Establishing vegetation on a constructed fen in a post-mined landscape in Alberta's oil sands region: a fouryear evaluation after species introduction. Ecol. Eng. 130, 11-22. doi: 10.1016/ j.ecoleng.2019.01.023

Bornette, G., Tabacchi, E., Hupp, C., Puijalon, S., and Rostan, J. C. (2008). A model of plant strategies in fluvial hydrosystems. Freshw. Biol. 53, 1692-1705. doi: 10.1111/j.1365-2427.2008.01994.x

Bouma, T. J., Temmerman, S., van Duren, L. A., Martini, E., Vandenbruwaene, W., Callaghan, D. P., et al. (2013). Organism traits determine the strength of scaledependent bio-geomorphic feedbacks: a flume study on three intertidal plant species. Geomorphology 18, 57-65. doi: 10.1016/j.geomorph.2012.09.005

Bouma, T. J., van Belzen, J., Balke, T., Zhu, Z., Airoldi, L., Blight, A. J., et al. (2014). Identifying knowledge gaps hampering application of intertidal habitats in coastal protection: opportunities \& steps to take. Coast. Eng. 87, 147-157. doi: 10.1016/j.coastaleng.2013.11.014

Bourgeois, B., Lemay, M.-A., Landry, T., Rochefort, L., and Poulin, M. (2019). Seed storage behaviour of eight peatland pool specialists: implications for restoration. Aquat. Bot. 152, 59-63. doi: 10.1016/j.aquabot.2018.09.008

Boutin, C., and Keddy, P. A. (1993). A functional classification of wetland plants. J. Veg. Sci. 4, 591-600. doi: 10.2307/3236124

Bower, A. D., St Clair, J. B., and Erickson, V. (2014). Generalized provisional seed zones for native plants. Ecol. Appl. 24, 913-919. doi: 10.1890/13-0285.1 
Boyer, K. E., and Zedler, J. B. (1998). Effects of nitrogen additions on the vertical structure of a constructed cordgrass marsh. Ecol. Appl. 8, 692-705. doi: 10.1890/ 1051-0761(1998)008[0692:eonaot]2.0.co;2

Bradford, K. J. (1986). Manipulation of seed water relations via osmotic priming to improve germination under stress conditions. HortScience 21, 1105-1112.

Brändel, M. (2006). Effect of temperatures on dormancy and germination in three species in the Lamiaceae occurring in northern wetlands. Wetlands Ecol. Manag. 14, 11-28. doi: 10.1007/s11273-005-1548-5

Brander, L., Brouwer, R., and Wagtendonk, A. (2013). Economic valuation of regulating services provided by wetlands in agricultural landscapes: a metaanalysis. Ecol. Eng. 56, 89-96. doi: 10.1016/j.ecoleng.2012.12.104

Breed, M. F., Harrison, P. A., Bischoff, A., Durruty, P., Gellie, N. J. C., Gonzales, E. K., et al. (2018). Priority actions to improve provenance decision-making. BioScience 68, 510-516. doi: 10.1093/biosci/biy050

Breed, M. F., Stead, M. G., Ottewell, K. M., Gardner, M. G., and Lowe, A. J. (2013). Which provenance and where? Seed sourcing strategies for revegetation in a changing environment. Conserv. Genet. 14, 1-10. doi: 10.1007/s10592-0120425-z

Broadhurst, L. M., Jones, T. A., Smith, F. S., North, T., and Guja, L. (2016). Maximizing seed resources for restoration in an uncertain future. Bioscience 66, 73-79. doi: 10.1093/biosci/biv155

Broadhurst, L. M., Lowe, A., Coates, D. J., Cunningham, S. A., McDonald, M., Vesk, P. A., et al. (2008). Seed supply for broadscale restoration: maximizing evolutionary potential. Evol. Appl. 1, 587-597.

Brock, M. A., Nielsen, D. L., Shiel, R. J., Green, J. D., and Langley, J. D. (2003). Drought and aquatic community resilience: the role of eggs and seeds in sediments of temporary wetlands. Freshw. Biol. 48, 1207-1218. doi: 10.1046/ j.1365-2427.2003.01083.x

Broek, T. van den, van Diggelen, R., and Bobbink, R. (2005). Variation in seed buoyancy of species in wetland ecosystems with different flooding dynamics. J. Veg. Sci. 16, 579-586. doi: 10.1111/j.1654-1103.2005.tb02399.x

Broome, S. W., Seneca, E. D., and Woodhouse, W. W. Jr. (1988). Tidal salt marsh restoration. Aquat. Bot. 32, 1-22.

Brown, R. L., and Fridley, J. D. (2003). Control of plant species diversity and community invasibility by species immigration: seed richness versus seed density. Oikos 102, 15-24. doi: 10.1034/j.1600-0706.2003.12191.x

Bruno, J. F., and Bertness, M. D. (2001). "Habitat modification and facilitation in benthic marine communities. Sinauer, Sunderland," Marine Community Ecology eds M. D. Bertness et al. (Sunderland: Sinauer Associates).

Bucharova, A., Bossdorf, O., Hölzel, N., Kollmann, J., Prasse, R., and Durka, W. (2019). Mix and match: regional admixture provenancing strikes a balance among different seed-sourcing strategies for ecological restoration. Conserv. Genet. 20, 7-17. doi: 10.1007/s10592-018-1067-6

Budelsky, R. A., and Galatowitsch, S. M. (1999). Effects of moisture, temperature, and time on seed germination of five wetland Carices: implications for restoration. Restor. Ecol. 7, 86-97. doi: 10.1046/j.1526-100x.1999. 07110.x

Budelsky, R. A., and Galatowitsch, S. M. (2000). Effects of water regime and competition on the establishment of a native sedge in restored wetlands. J. Appl. Ecol. 37, 971-985. doi: 10.1046/j.1365-2664.2000.00540.x

Bureau of Land Management (2018). Technical protocol for the collection, study, and conservation of seeds from native plant species for Seeds of Success. Washington, DC: Bureau of Land Management.

Burke, M. J., and Grime, J. P. (1996). An experimental study of plant community invasibility. Ecology 77, 776-790. doi: 10.2307/2265501

Burton, C. M., Burton, P. J., Hebda, R., and Turner, N. J. (2006). Determining the optimal sowing density for a mixture of native plants used to revegetate degraded ecosystems. Restor. Ecol. 14, 379-390. doi: 10.1111/j.1526-100x.2006. 00146.x

Busch, K. E., Golden, R. R., Parham, T. A., Karrh, L. P., Lewandowski, M. J., and Naylor, M. D. (2010). Large-scale Zostera marina (eelgrass) restoration in Chesapeake Bay, Maryland, USA. Part I: a comparison of techniques and associated costs. Restor. Ecol. 18, 490-500. doi: 10.1111/j.1526-100x.2010. 00690.x

Butterfield, B. J., Copeland, S. M., Munson, S. M., Roybal, C. M., and Wood, T. E. (2017). Prestoration: using species in restoration that will persist now and into the future. Restor. Ecol. 25, S155-S163.
Byun, C., de Blois, S., and Brisson, J. (2013). Plant functional group identity and diversity determine biotic resistance to invasion by an exotic grass. J. Ecol. 101, 128-139. doi: 10.1111/1365-2745.12016

Byun, C., de Blois, S., and Brisson, J. (2015). Interactions between abiotic constraint, propagule pressure, and biotic resistance regulate plant invasion. Oecologia 178, 285-296. doi: 10.1007/s00442-014-3188-z

Byun, C., de Blois, S., and Brisson, J. (2018). Management of invasive plants through ecological resistance. Biol. Invasions 20, 13-27. doi: 10.1007/s10530017-1529-7

Byun, C., Oh, M., Lee, E. J., and Kang, H. (2020). Seed density is as important as limiting similarity, diversity effect, and propagule pressure in plant restoration to control invasion. Ecol. Eng. 144:105712. doi: 10.1016/j.ecoleng.2019.105712

Carta, A. (2016). Seed regeneration in Mediterranean temporary ponds: germination ecophysiology and vegetation processes. Hydrobiologia 782, 23-35. doi: 10.1007/s10750-016-2808-5

Carta, A., Bedini, G., Müller, J. V., and Probert, R. J. (2013). Comparative seed dormancy and germination of eight annual species of ephemeral wetland vegetation in a Mediterranean climate. Plant Ecol. 214, 339-349. doi: 10.1007/ s11258-013-0174-1

Carta, A., Probert, R., Puglia, G., Peruzzi, L., and Bedini, G. (2016). Local climate explains degree of seed dormancy in Hypericum elodes L. (Hypericaceae). Plant Biol. 18, 76-82. doi: 10.1111/plb.12310

Casanova, M. T., and Brock, M. A. (2000). How do depth, duration and frequency of flooding influence the establishment of wetland plant communities? Plant Ecol. 147, 237-250.

Chambers, J. C., and MacMahon, J. A. (1994). A day in the life of a seed: movements and fates of seeds and their implications for natural and managed systems. Ann. Rev. Ecol. Syst. 25, 263-292. doi: 10.1146/annurev.es.25.110194.001403

Chevin, L.-M., Lande, R., and Mace, G. M. (2010). Adaptation, plasticity, and extinction in a changing environment: towards a predictive theory. PLoS Biol. 8:e1000357. doi: 10.1371/journal.pbio.1000357

Cleland, E. E., Esch, E., and McKinney, J. (2015). Priority effects vary with species identity and origin in an experiment varying the timing of seed arrival. Oikos 124, 33-40. doi: 10.1111/oik.01433

Coops, H., and van der Velde, G. (1995). Seed dispersal, germination and seedling growth of six helophyte species in relation to water-level zonation. Freshw. Biol. 34, 13-20. doi: 10.1111/j.1365-2427.1995.tb00418.x

Coppi, A., Lastrucci, L., Carta, A., and Foggi, B. (2015). Analysis of genetic structure of Ranunculus baudotii in a Mediterranean wetland. Implications for selection of seeds and seedlings for conservation. Aquat. Bot. 126, 25-31. doi: 10.1016/j.aquabot.2015.06.002

Corbin, J. D., and D’Antonio, C. M. (2012). Gone but not forgotten? Invasive plants' legacies on community and ecosystem properties. Invasive Plant Sci. Manag. 5, 117-124. doi: 10.1614/ipsm-d-11-00005.1

Cronk, J. K., and Fennessy, M. S. (2001). Wetland Plants: Biology and Ecology. Boca Raton, FL: CRC Press.

Daehler, C. C., and Strong, D. R. (1996). Status, prediction and prevention of introduced cordgrass Spartina spp. invasions in Pacific estuaries, USA. Biol. Conserv. 78, 51-58. doi: 10.1016/0006-3207(96)00017-1

Daniel, J., Gleason, J. E., Cottenie, K., and Rooney, R. C. (2019). Stochastic and deterministic processes drive wetland community assembly across a gradient of environmental filtering. Oikos 128, 1158-1169. doi: 10.1111/oik. 05987

Daniels, W. L., Perry, J. E., Whittecar, R. G., Fajardo, G., Bergschneider, C., and Despres, A. (2005). Effects of Soil Amendments and Other Practices Upon the Success of the Virginia Department of Transportation's Non-Tidal Wetland Mitigation Efforts. Virginia: Center for Transportation Innovation and Research.

D’Antonio, C., and Meyerson, L. A. (2002). Exotic plant species as problems and solutions in ecological restoration: a synthesis. Restor. Ecol. 10, 703-713. doi: 10.1046/j.1526-100x.2002.01051.x

Davis, M. A., Grime, J. P., and Thompson, K. (2000). Fluctuating resources in plant communities: a general theory of invasibility. J. Ecol. 88, 528-534. doi: 10.1046/j.1365-2745.2000.00473.x

Dawson, S. K., Catford, J. A., Berney, P., Kingsford, R. T., and Capon, S. (2020). Land use alters soil propagule banks of wetlands down the soil-depth profile. Mar. Freshw. Res. 71, 191-201. 
Dawson, S. K., Kingsford, R. T., Berney, P., Keith, D. A., Hemmings, F. A., Warton, D. I., et al. (2017). Frequent inundation helps counteract land use impacts on wetland propagule banks. Appl. Veg. Sci. 20, 459-467. doi: 10.1111/avsc.12295

De Vitis, M. D., Hay, F. R., Dickie, J. B., Trivedi, C., Choi, J., and Fiegener, R. (2020). Seed storage: maintaining seed viability and vigor for restoration use. Restor. Ecol. 1-7.

Densmore, R., and Zasada, J. (1983). Seed dispersal and dormancy patterns in northern willows: ecological and evolutionary significance. Can. J. Bot. 61, 3207-3216. doi: 10.1139/b83-358

Denzler, A. A. (2017). Hydromulching in Tidally Influenced Wetlands: Testing Methods to Alleviate Seed Wash-Away and Revegetate Native Plant Communities. Available online at: http://archives.evergreen.edu/masterstheses/ Accession86-10MES/Denzler_AMESthesis2017.pdf (accessed March 24, 2020).

Dickens, S. J. M., Mangla, S., Preston, K. L., and Suding, K. N. (2016). Embracing variability: environmental dependence and plant community context in ecological restoration. Restor. Ecol. 24, 119-127. doi: 10.1111/rec.12288

Dietert, M. F., and Shontz, J. P. (1978). Germination ecology of a Maryland population of saltmarsh bulrush (Scirpus robustus). Estuaries 1, 164-170.

Doherty, J. M., Callaway, J. C., and Zedler, J. B. (2011). Diversity-function relationships changed in a long-term restoration experiment. Ecol. Appl. 21, 2143-2155. doi: 10.1890/10-1534.1

Doherty, J. M., Miller, J. F., Prellwitz, S. G., Thompson, A. M., Loheide, S. P., and Zedler, J. B. (2014). Hydrologic regimes revealed bundles and tradeoffs among six wetland services. Ecosystems 17, 1026-1039. doi: 10.1007/s10021-014-9775-

Doherty, J. M., and Zedler, J. B. (2015). Increasing substrate heterogeneity as a bet-hedging strategy for restoring wetland vegetation. Restor. Ecol. 23, 15-25. doi: 10.1111/rec.12154

Donnelly, J. P., King, S. L., Silverman, N. L., Collins, D. P., Carrera-Gonzalez, E. M., Lafón-Terrazas, A., et al. (2020). Climate and human water use diminish wetland networks supporting continental waterbird migration. Glob. Change Biol. 26, 2042-2059. doi: $10.1111 / \mathrm{gcb} .15010$

Donohue, K., Rubio de Casas, R., Burghardt, L., Kovach, K., and Willis, C. G. (2010). Germination, postgermination adaptation, and species ecological ranges. Ann. Rev. Ecol. Evol. Systemat. 41, 293-319. doi: 10.1146/annurevecolsys-102209-144715

Dormann, C. F., van der Wal, R., and Bakker, J. P. (2000). Competition and herbivory during salt marsh succession: the importance of forb growth strategy. J. Ecol. 88, 571-583. doi: 10.1046/j.1365-2745.2000.00469.x

Downard, R., Endter-Wada, J., and Kettenring, K. M. (2014). Adaptive wetland management in an uncertain and changing arid environment. Ecol. Soc. 19:23.

Drayton, B., and Primack, R. B. (2000). Rates of success in the reintroduction by four methods of several perennial plant species in eastern Massachusetts. Rhodora 102, 299-331.

Drayton, B., and Primack, R. B. (2012). Success rates for reintroductions of eight perennial plant species after 15 years. Restor. Ecol. 20, 299-303. doi: 10.1111/j. 1526-100x.2011.00860.x

Dreesen, D. (2004). Tumbling for seed cleaning and conditioning. Native Plants J. 5, 52-54. doi: 10.1353/npj.2004.0008

Duarte, C. M., Losada, I. J., Hendriks, I. E., Mazarrasa, I., and Marbà, N. (2013). The role of coastal plant communities for climate change mitigation and adaptation. Nat. Climate Change 3, 961-968. doi: 10.1038/nclimate 1970

Ehrenfeld, J. G. (2003). Effects of exotic plant invasions on soil nutrient cycling processes. Ecosystems 6, 503-523. doi: 10.1007/s10021-002-0151-3

Eisele, F., and Hwang, B. S. (2019). New UN Decade on Ecosystem Restoration Offers Unparalleled Opportunity for Job Creation, Food Security and Addressing Climate Change. Available online at: http://www.unenvironment.org/newsand-stories/press-release/new-un-decade-ecosystem-restoration-offersunparalleled-opportunity (accessed June 22, 2020).

Elzinga, C. L., Salzer, D. W., and Willoughby, J. W. (1998). Measuring \& Monitering Plant Populations. Washington, DC: US Bureau of Land Management.

Endter-Wada, J., Kettenring, K. M., and Sutton-Grier, A. (2020). Protecting wetlands for people: strategic policy action can help wetlands mitigate risks and enhance resilience. Environ. Sci. Policy 108, 37-44. doi: 10.1016/j.envsci.2020. 01.016
Endter-Wada, J., Kettenring, K. M., and Sutton-Grier, A. E. (2018). Sustaining wetlands to mitigate disasters and protect people. Front. Ecol. Environ. 16:431. doi: $10.1002 /$ fee. 1959

England, D. M. (2019). Seeding treatments to enhance seedling performance of the bulrushes Bolboschoenus maritimus, Schoenoplectus acutus, and S. americanus in wetland restorations. Masters thesis, Utah State University, Logan.

ENSCONET (2009). ENSCONET seed Collecting Manual for Wild Species. Madrid: Universidad Politécnica de Madrid.

Espeland, E. K., Emery, N. C., Mercer, K. L., Woolbright, S. A., Kettenring, K. M., Gepts, P., et al. (2017). Evolution of plant materials for ecological restoration: insights from the applied and basic literature. J. Appl. Ecol. 54, 102-115. doi: 10.1111/1365-2664.12739

Espeland, E. K., Johnson, R. C., and Horning, M. E. (2018). Plasticity in native perennial grass populations: implications for restoration. Evol. Appl. 11, 340349. doi: $10.1111 /$ eva. 12560

Espeland, E. K., and Kettenring, K. M. (2018). Strategic plant choices can alleviate climate change impacts: a review. J. Environ. Manag. 222, 316-324. doi: 10. 1016/j.jenvman.2018.05.042

Evans, M. E., and Dennehy, J. J. (2005). Germ banking: bet-hedging and variable release from egg and seed dormancy. Q. Rev. Biol. 80, 431-451. doi: 10.1086/ 498282

Facelli, J. M., and Pickett, S. T. (1991). Plant litter: its dynamics and effects on plant community structure. Bot. Rev. 57, 1-32. doi: 10.1007/bf02858763

Farnsworth, E. (2000). The ecology and physiology of viviparous and recalcitrant seeds. Ann. Rev. Ecol. Systemat. 31, 107-138. doi: 10.1146/annurev.ecolsys.31. 1.107

Farooq, M., Irfan, M., Aziz, T., Ahmad, I., and Cheema, S. A. (2013). Seed priming with ascorbic acid improves drought resistance of wheat. J. Agron. Crop Sci. 199, 12-22. doi: 10.1111/j.1439-037x.2012.00521.x

Farrer, E. C., and Goldberg, D. E. (2014). Mechanisms and reversibility of the effects of hybrid cattail on a Great Lakes marsh. Aquat. Bot. 116, 35-43. doi: 10.1016/j.aquabot.2014.01.002

Fernández-Pascual, E. (2016). Comparative seed germination traits in bog and fen mire wetlands. Aquat. Bot. 130, 21-26. doi: 10.1016/j.aquabot.2016.01.001

Figuerola, J., Santamaría, L., Green, A. J., Luque, I., Alvarez, R., and Charalambidou, I. (2005). Endozoochorous dispersal of aquatic plants: does seed gut passage affect plant performance? Am. J. Bot. 92, 696-699. doi: 10. 3732/ajb.92.4.696

Findlay, S., Groffman, P., and Dye, S. (2003). Effects of Phragmites australis removal on marsh nutrient cycling. Wetlands Ecol. Manag. 11, 157-165.

Finlayson, C. M., Davies, G. T., Moomaw, W. R., Chmura, G. L., Natali, S. M., Perry, J. E., et al. (2018). The second warning to humanity-providing a context for wetland management and policy. Wetlands 39, 1-5. doi: 10.1007/s13157018-1064-z

Fivash, G. S., van Belzen, J., Temmink, R. J. M., Didderen, K., Lengkeek, W., van der Heide, T., et al. (2020). Elevated micro-topography boosts growth rates in Salicornia procumbens by amplifying a tidally driven oxygen pump: implications for natural recruitment and restoration. Ann. Bot. 125, 353-364.

Fraser, L. H., and Karnezis, J. P. (2005). A comparative assessment of seedling survival and biomass accumulation for fourteen wetland plant species grown under minor water-depth differences. Wetlands 25, 520-530. doi: 10.1672/ 0277-5212(2005)025[0520:acaoss]2.0.co;2

Friess, D. A., Krauss, K. W., Horstman, E. M., Balke, T., Bouma, T. J., Galli, D., et al. (2012). Are all intertidal wetlands naturally created equal? Bottlenecks, thresholds and knowledge gaps to mangrove and saltmarsh ecosystems. Biol. Rev. 87, 346-366. doi: 10.1111/j.1469-185x.2011.00198.x

Frieswyk, C. B., Johnston, C. A., and Zedler, J. B. (2007). Identifying and characterizing dominant plants as an indicator of community condition. J. Great Lakes Res. 33, 125-135. doi: 10.3394/0380-1330(2007)33[125:iacdpa] 2.0.co;2

Funk, J. L., Cleland, E. E., Suding, K. N., and Zavaleta, E. S. (2008). Restoration through reassembly: plant traits and invasion resistance. Trends Ecol. Evol. 23, 695-703. doi: 10.1016/j.tree.2008.07.013

Galatowitsch, S. M. (2006). Restoring prairie pothole wetlands: does the species pool concept offer decision-making guidance for re-vegetation? Appl. Veg. Sci. 9, 261-270. doi: 10.1111/j.1654-109x.2006.tb00675.x 
Galatowitsch, S. M., Anderson, N. O., and Ascher, P. D. (1999). Invasiveness in wetland plants in temperate North America. Wetlands 19, 733-755. doi: $10.1007 /$ bf03161781

Galatowitsch, S. M., and Richardson, D. M. (2005). Riparian scrub recovery after clearing of invasive alien trees in headwater streams of the Western Cape. South Africa. Biol. Conserv. 122, 509-521. doi: 10.1016/j.biocon.2004.09.008

Galatowitsch, S. M., and van der Valk, A. G. (1994). Restoring Prairie Wetlands: An Ecological Approach. Iowa: Iowa State University Press.

Galatowitsch, S. M., and van der Valk, A. G. (1996). The vegetation of restored and natural prairie wetlands. Ecol. Appl. 6, 102-112. doi: 10.2307/2269557

Ge, Z.-M., Li, S.-H., Tan, L.-S., Li, Y.-L., and Hu, Z.-J. (2019). The importance of the propagule-sediment-tide "power balance" for revegetation at the coastal frontier. Ecol. Appl. 29:e01967.

Ghalambor, C. K., McKay, J. K., Carroll, S. P., and Reznick, D. N. (2007). Adaptive versus non-adaptive phenotypic plasticity and the potential for contemporary adaptation in new environments. Funct. Ecol. 21, 394-407. doi: 10.1111/j.13652435.2007.01283.x

Gioria, M., and Pyšek, P. (2017). Early bird catches the worm: germination as a critical step in plant invasion. Biol. Invasions 19, 1055-1080. doi: 10.1007/ s10530-016-1349-1

Giroux, J.-F., and Bédard, J. (1995). Seed production, germination rate, and seedling establishment of Scirpus pungens in tidal brackish marshes. Wetlands 15, 290-297. doi: 10.1007/bf03160709

Godefroid, S., Piazza, C., Rossi, G., Buord, S., Stevens, A.-D., Aguraiuja, R., et al. (2011). How successful are plant species reintroductions? Biol. Conserv. 144, 672-682. doi: 10.1016/j.biocon.2010.10.003

Gornish, E., Arnold, H., and Fehmi, J. (2019). Review of seed pelletizing strategies for arid land restoration. Restor. Ecol. 27, 1206-1211. doi: 10.1111/rec.13045

Greet, J., Ede, F., Robertson, D., and McKendrick, S. (2020). Should I plant or should I sow? Restoration outcomes compared across seven riparian revegetation projects. Ecol. Manag. Restor. 21, 58-65. doi: 10.1111/emr.12396

Grewell, B. J., Espeland, E. K., and Fiedler, P. L. (2013). Sea change under climate change: case studies in rare plant conservation from the dynamic San Francisco Estuary. Botany 91, 309-318. doi: 10.1139/cjb-2012-0300

Grewell, B. J., Gillard, M. B., Futrell, C. J., and Castillo, J. M. (2019). Seedling emergence from seed banks in Ludwigia hexapetala-Invaded Wetlands: implications for Restoration. Plants 8:451. doi: 10.3390/plants811 0451

Grime, J. P., Mason, G., Curtis, A. V., Rodman, J., Band, S. R., Mowforth M. A. G., et al. (1981). A comparative study of germination characteristics in a local flora. J. Ecol. 69, 1017-1059.

Grman, E., and Suding, K. N. (2010). Within-year soil legacies contribute to strong priority effects of exotics on native California grassland communities. Restor. Ecol. 18, 664-670. doi: 10.1111/j.1526-100x.2008.00497.x

Grossnickle, S. C., and Ivetić, V. (2017). Direct seeding in reforestation-a field performance review. Reforesta 4, 94-142. doi: 10.21750/refor.4.07.46

Groves, A. M., and Brudvig, L. A. (2019). Interannual variation in precipitation and other planting conditions impacts seedling establishment in sown plant communities. Restor. Ecol. 27, 128-137. doi: 10.1111/rec.12708

Gutterman, Y. (2000). Maternal effects on seeds during development. Seeds: The Ecology of Regeneration in Plant Communities. 59-84. doi: 10.1079/ 9780851994321.0059

Haidet, M., and Olwell, P. (2015). Seeds of success: a national seed banking program working to achieve long-term conservation goals. Nat. Areas J. 35, 165-173. doi: 10.3375/043.035.0118

Halpern, B. S., Silliman, B. R., Olden, J. D., Bruno, J. P., and Bertness, M. D. (2007). Incorporating positive interactions in aquatic restoration and conservation. Front. Ecol. Environ. 5, 153-160. doi: 10.1890/1540-9295(2007)5[153:IPIIAR] 2.0.CO;2

Hancock, N., Gibson-Roy, P., Driver, M., and Broadhurst, L. (2020). The Australian Native Seed Sector Survey Report. Canberra: Australian Network for Plant Conservation, 90.

Hangelbroek, H. H., Ouborg, N. J., Santamaría, L., and Schwenk, K. (2002). Clonal diversity and structure within a population of the pondweed Potamogeton pectinatus foraged by Bewick's swans. Mol. Ecol. 11, 2137-2150. doi: 10.1046/j. 1365-294x.2002.01598.x
Haramis, G. M., and Kearns, G. D. (2007). Herbivory by resident geese: the loss and recovery of wild rice along the tidal Patuxent River. J. Wildl. Manag. 71, 788-794. doi: 10.2193/2006-350

Hardegree, S. P., and Van Vactor, S. S. (2000). Germination and emergence of primed grass seeds under field and simulated-field temperature regimes. Ann. Bot. 85, 379-390. doi: 10.1006/anbo.1999. 1076

Harper, J. L. (1977). Population Biology of Plants. Cambridge, MA: Academic Press. Harper, J. L., Williams, J. T., and Sagar, G. R. (1965). The behaviour of seeds in soil: I. The heterogeneity of soil surfaces and its role in determining the establishment of plants from seed. J. Ecol. 53, 273-286.

Havens, K., Vitt, P., Still, S., Kramer, A. T., Fant, J. B., and Schatz, K. (2015). Seed sourcing for restoration in an era of climate change. Nat. Areas J. 35, 122-133. doi: $10.3375 / 043.035 .0116$

Hay, F. R., and Probert, R. J. (2013). Advances in seed conservation of wild plant species: a review of recent research. Conserv. Physiol. 1, 1-11.

Hazelton, E. L., Mozdzer, T. J., Burdick, D. M., Kettenring, K. M., and Whigham, D. F. (2014). Phragmites australis management in the United States: 40 years of methods and outcomes. AoB Plants 6, 1-19.

Hess, M. C. M., Mesléard, F., and Buisson, E. (2019). Priority effects: emerging principles for invasive plant species management. Ecol. Eng. 127, 48-57. doi: 10.1016/j.ecoleng.2018.11.011

Himanen, K., Nygren, M., and Dumroese, R. K. (2012). Boiling water scarification plus stratification improves germination of Iliamna rivularis (Malvaceae) seeds. Native Plants J. 13, 244-256. doi: 10.3368/npj.13.3.244

Hoag, J. C., Tilley, D., Ogle, D., and St John, L. (2011). Description, Propagation, And Establishment Of Wetland-Riparian Grass And Grass-Like Species In The Intermountain West. Washington, DC: USDA.

Holdredge, C., and Bertness, M. D. (2011). Litter legacy increases the competitive advantage of invasive Phragmites australis in New England wetlands. Biol. Invasions 13, 423-433. doi: 10.1007/s10530-010-9836-2

Holguin, G., Vazquez, P., and Bashan, Y. (2001). The role of sediment microorganisms in the productivity, conservation, and rehabilitation of mangrove ecosystems: an overview. Biol. Fertil. Soils 33, 265-278. doi: 10.1007/ s003740000319

Holl, K. D., and Aide, T. M. (2011). When and where to actively restore ecosystems? Forest Ecol. Manag. 261, 1558-1563. doi: 10.1016/j.foreco.2010.07.004

Houck, M. (2009). Understanding Seeding Rates, Recommended Planting Rates, and Pure Live Seed. Washington, DC: USDA.

Howard, R. J. (2010). Intraspecific variation in growth of marsh macrophytes in response to salinity and soil type: implications for wetland restoration. Estuar. Coasts 33, 127-138. doi: 10.1007/s12237-009-9227-z

Hufford, K. M., and Mazer, S. J. (2003). Plant ecotypes: genetic differentiation in the age of ecological restoration. Trends Ecol. Evol. 18, 147-155. doi: 10.1016/ s0169-5347(03)00002-8

Hughes, A. R., Inouye, B. D., Johnson, M. T., Underwood, N., and Vellend, M. (2008). Ecological consequences of genetic diversity. Ecol. Lett. 11, 609-623. doi: 10.1111/j.1461-0248.2008.01179.x

Hughes, A. R., and Stachowicz, J. J. (2004). Genetic diversity enhances the resistance of a seagrass ecosystem to disturbance. Proc. Natl. Acad. Sci. U.S.A. 101, 8998-9002. doi: 10.1073/pnas.0402642101

Hugron, S., Guêné-Nanchen, M., Roux, N., LeBlanc, M.-C., and Rochefort, L. (2020). Plant reintroduction in restored peatlands: $80 \%$ successfully transferred - Does the remaining 20\% matter? Glob. Ecol. Conserv. 22, e01000. doi: 10.1016/j.gecco.2020.e01000

Hussner, A., Stiers, I., Verhofstad, M. J. J. M., Bakker, E. S., Grutters, B. M. C., Haury, J., et al. (2017). Management and control methods of invasive alien freshwater aquatic plants: a review. Aquat. Bot. 136, 112-137. doi: 10.1016/j. aquabot.2016.08.002

Iannone, B. V. III., and Galatowitsch, S. M. (2008). Altering light and soil N to limit Phalaris arundinacea reinvasion in sedge meadow restorations. Restor. Ecol. 16, 689-701. doi: 10.1111/j.1526-100x.2008.00481.x

Ignacio Galinato, M., and van der Valk, A. G. (1986). Seed germination traits of annuals and emergents recruited during drawdowns in the Delta Marsh, Manitoba, Canada. Aquat. Bot. 26, 89-102. doi: 10.1016/0304-3770(86)90 007-0 
Isselin-Nondedeu, F., and Gaucherand, S. (2019). Transplanting success of two alpine plant species in combination with mulching during restoration of a highelevation peatland. Wetlands Ecol. Manag. 28, 71-84. doi: 10.1007/s11273-01909695-y

James, J. J., and Carrick, P. J. (2016). Toward quantitative dryland restoration models. Restor. Ecol. 24, S85-S90.

James, J. J., Svejcar, T. J., and Rinella, M. J. (2011). Demographic processes limiting seedling recruitment in arid grassland restoration. J. Appl. Ecol. 48, 961-969. doi: 10.1111/j.1365-2664.2011.02009.x

Jensen, K. (2004a). Dormancy patterns, germination ecology, and seed-bank types of twenty temperate fen grassland species. Wetlands 24, 152-166. doi: 10.1672/ 0277-5212(2004)024[0152:dpgeas]2.0.co;2

Jensen, S. (2004b). Racquets, hoppers, and felt boards-low-tech devices for processing seeds. Native Plants J. 5, 50-51. doi: 10.1353/npj.2004.0013

Johnson, G. R., Sorensen, F. C., St Clair, J. B., and Cronn, R. C. (2004). Pacific Northwest Forest Tree Seed Zones A template for native plants? Native Plants J. 5, 131-140. doi: 10.2979/npj.2004.5.2.131

Jordan, R., Breed, M. F., Prober, S. M., Miller, A. D., and Hoffmann, A. A. (2019). How well do revegetation plantings capture genetic diversity? Biol. Lett. 15:20190460. doi: 10.1098/rsbl.2019.0460

Jordan, R. A., and Hartman, J. M. (1995). Safe sites and the regeneration of Clethra alnifolia L. (Clethraceae) in Wetland Forests of Central New Jersey. Am. Midland Nat. 133, 112-123.

Jump, A. S., and Peñuelas, J. (2005). Running to stand still: adaptation and the response of plants to rapid climate change. Ecol. Lett. 8, 1010-1020. doi: 10.1111/j.1461-0248.2005.00796.x

Kaproth, M. A., Eppinga, M. B., and Molofsky, J. (2013). Leaf litter variation influences invasion dynamics in the invasive wetland grass Phalaris arundinacea. Biol. Invasions 15, 1819-1832. doi: 10.1007/s10530-013-0411-5

Kauth, P. J., and Biber, P. D. (2015). Moisture content, temperature, and relative humidity influence seed storage and subsequent survival and germination of Vallisneria americana seeds. Aquat. Bot. 120, 297-303. doi: 10.1016/j.aquabot. 2014.09.009

Kettenring, K. M. (2016). Viability, dormancy, germination, and intraspecific variation of Bolboschoenus maritimus (alkali bulrush) seeds. Aquat. Bot. 134, 26-30. doi: 10.1016/j.aquabot.2016.06.005

Kettenring, K. M., and Adams, C. R. (2011). Lessons learned from invasive plant control experiments: a systematic review and meta-analysis. J. Appl. Ecol. 48, 970-979. doi: 10.1111/j.1365-2664.2011.01979.x

Kettenring, K. M., and Galatowitsch, S. M. (2007a). Temperature requirements for dormancy break and seed germination vary greatly among 14 wetland Carex species. Aquat. Bot. 87, 209-220. doi: 10.1016/j.aquabot.2007.06.003

Kettenring, K. M., and Galatowitsch, S. M. (2007b). Tools for Carex revegetation in freshwater wetlands: understanding dormancy loss and germination temperature requirements. Plant Ecol. 193, 157-169. doi: 10.1007/s11258-0069255-8

Kettenring, K. M., and Galatowitsch, S. M. (2011a). Carex seedling emergence in restored and natural prairie wetlands. Wetlands 31, 273-281. doi: 10.1007/ s13157-011-0160-0

Kettenring, K. M., and Galatowitsch, S. M. (2011b). Seed rain of restored and natural prairie wetlands. Wetlands 31, 283-294. doi: 10.1007/s13157-0110159-6

Kettenring, K. M., Gardner, G., and Galatowitsch, S. M. (2006). Effect of light on seed germination of eight wetland Carex species. Ann. Bot. 98, 869-874. doi: $10.1093 / \mathrm{aob} / \mathrm{mcl} 170$

Kettenring, K. M., Menuz, D. R., and Mock, K. E. (2019a). The nativity and distribution of the cryptic invader Phalaris arundinacea (reed canarygrass) in riparian areas of the Columbia and Missouri River Basins. Wetlands 39, 55-66. doi: 10.1007/s13157-018-1074-x

Kettenring, K. M., Mossman, B. N., Downard, R., and Mock, K. E. (2019b). Fine-scale genetic diversity and landscape-scale genetic structuring in three foundational bulrush species: implications for wetland revegetation. Restor. Ecol. 27, 408-420. doi: 10.1111/rec.12884

Kettenring, K. M., Mercer, K. L., Reinhardt Adams, C., and Hines, J. (2014). Application of genetic diversity-ecosystem function research to ecological restoration. J. Appl. Ecol. 51, 339-348. doi: 10.1111/1365-2664.12202

Keyport, S., Carson, B. D., Johnson, O., Lawrence, B. A., Lishawa, S. C., Tuchman, N. C., et al. (2019). Effects of experimental harvesting of an invasive hybrid cattail on wetland structure and function. Restor. Ecol. 27, 389-398. doi: 10. $1111 /$ rec. 12859

Kildisheva, O. A., Dixon, K. W., Silveira, F. A. O., Chapman, T., Sacco, A. D., Mondoni, A., et al. (2020). Dormancy and germination: making every seed count in restoration. Restor. Ecol. 1-10.

Kildisheva, O. A., Erickson, T. E., Merritt, D. J., and Dixon, K. W. (2016). Setting the scene for dryland recovery: an overview and key findings from a workshop targeting seed-based restoration. Restor. Ecol. 24, S36-S42.

Kimura, E., and Islam, M. A. (2012). Seed scarification methods and their use in forage legumes. Res. J. Seed Sci. 5, 38-50. doi: 10.3923/rjss.2012.38.50

King, J. G., and Hadfield, J. D. (2019). The evolution of phenotypic plasticity when environments fluctuate in time and space. Evol. Lett. 3, 15-27. doi: 10.1002/ evl3.100

Kleyheeg, E., and van Leeuwen, C. H. (2015). Regurgitation by waterfowl: an overlooked mechanism for long-distance dispersal of wetland plant seeds. Aquat. Bot. 127, 1-5. doi: 10.1016/j.aquabot.2015.06.009

Kotowska, A. M., Cahill, J. F. Jr., and Keddie, B. A. (2010). Plant genetic diversity yields increased plant productivity and herbivore performance. J. Ecol. 98, 237-245. doi: 10.1111/j.1365-2745.2009.01606.x

Kotze, D. C., Tererai, F., and Grundling P. L. (2019). Assessing, with limited resources, the ecological outcomes of wetland restoration: a South African case. Restor. Ecol. 27, 495-503. doi: 10.1111/rec.12891

Laberge, V., Hugron, S., Rochefort, L., and Poulin, M. (2015). Influence of different bryophyte carpets on vascular plant establishment around pools in restored peatlands. Land Degrad. Dev. 26, 813-818. doi: 10.1002/ldr. 2243

Ladouceur, E., Jiménez-Alfaro, B., Marin, M., De Vitis, M., Abbandonato, H., Iannetta, P. P., et al. (2018). Native seed supply and the restoration species pool. Conserv. Lett. 11:e12381. doi: 10.1111/conl.12381

Lamont, B. B., Marsula, R., Enright, N. J., and Witkowski, E. T. F. (2001). Conservation requirements of an exploited wildflower: modelling the effects of plant age, growing conditions and harvesting intensity. Biol. Cons. 99, 157-168. doi: 10.1016/s0006-3207(00)00164-6

Landry, T., Rochefort, L., and Poulin, M. (2012). Impact of seedbed and water level on the establishment of plant species associated with bog pools: implications for restoration. Native Plants J. 13, 205-215. doi: 10.3368/npj.13.3. 205

Larkin, D. J., Bruland, G. L., and Zedler, J. B. (2016). Heterogeneity Theory and Ecological Restoration. Berlin: Springer.

Larson, D. M., Riens, J., Myerchin, S., Papon, S., Knutson, M. G., Vacek, S. C., et al. (2019). Sediment excavation as a wetland restoration technique had early effects on the developing vegetation community. Wetlands Ecol. Manag. 28, 1-18. doi: 10.1007/s11273-019-09690-3

Larson, J. E., and Funk, J. L. (2016). Regeneration: an overlooked aspect of traitbased plant community assembly models. J. Ecol. 104, 1284-1298. doi: 10.1111/ 1365-2745.12613

Larson, J. E., Sheley, R. L., Hardegree, S. P., Doescher, P. S., and James, J. J. (2015). Seed and seedling traits affecting critical life stage transitions and recruitment outcomes in dryland grasses. J. Appl. Ecol. 52, 199-209. doi: 10.1111/1365-2664. 12350

Laughlin, D. C. (2014). Applying trait-based models to achieve functional targets for theory-driven ecological restoration. Ecol. Lett. 17, 771-784. doi: 10.1111/ ele. 12288

Lavergne, S., and Molofsky, J. (2006). Control strategies for the invasive reed canarygrass (Phalaris arundinacea L.) in North American wetlands: the need for an integrated management plan. Nat. Areas J. 26, 208-214. doi: 10.3375/ 0885-8608(2006)26[208:csftir]2.0.co;2

Leck, M. A. (1996). Germination of macrophytes from a Delaware River tidal freshwater wetland. Bull. Torrey Bot. Club 123, 48-67.

Leck, M. A., and Brock, M. A. (2000). Ecological and evolutionary trends in wetlands: evidence from seeds and seed banks in New South Wales, Australia and New Jersey, USA. Plant Species Biol. 15, 97-112. doi: 10.1046/j.1442-1984. 2000.00031.x

Leck, M. A., Parker, V. T., Simpson, R. L., and Simpson, R. S. (2008). Seedling Ecology and Evolution. Cambridge: Cambridge University Press.

Leck, M. A., and Schütz, W. (2005). Regeneration of Cyperaceae, with particular reference to seed ecology and seed banks. Perspect. Plant Ecol. Evol. Systemat. 7, 95-133. doi: 10.1016/j.ppees.2005.05.001 
Leger, E. A. (2008). The adaptive value of remnant native plants in invaded communities: an example from the Great Basin. Ecol. Appl. 18, 1226-1235. doi: $10.1890 / 07-1598.1$

Leger, E. A., and Baughman, O. W. (2015). What seeds to plant in the Great Basin? Comparing traits prioritized in native plant cultivars and releases with those that promote survival in the field. Nat. Areas J. 35, 54-68. doi: 10.3375/043.035. 0108

Leibowitz, S. G., Wigington, P. J. Jr., Schofield, K. A., Alexander, L. C., Vanderhoof, M. K., and Golden, H. E. (2018). Connectivity of streams and wetlands to downstream waters: an integrated systems framework. JAWRA 54, 298-322. doi: $10.1111 / 1752-1688.12631$

Leimu, R., and Fischer, M. (2008). A meta-analysis of local adaptation in plants. PLoS One 3:e4010. doi: 10.1371/journal.pone.0004010

Levine, J. M., Adler, P. B., and Yelenik, S. G. (2004). A meta-analysis of biotic resistance to exotic plant invasions. Ecol. Lett. 7, 975-989. doi: 10.1111/j.14610248.2004.00657.x

Liao, C., Peng, R., Luo, Y., Zhou, X., Wu, X., Fang, C., et al. (2008). Altered ecosystem carbon and nitrogen cycles by plant invasion: a meta-analysis. New Phytol. 177, 706-714. doi: 10.1111/j.1469-8137.2007.02290.x

Liao, Y.-Y., Yue, X.-L., Guo, Y.-H., Gituru, W. R., Wang, Q.-F., and Chen, J.-M. (2013). Genotypic diversity and genetic structure of populations of the distylous aquatic plant Nymphoides peltata (Menyanthaceae) in China. J. Systemat. Evol. 51, 536-544. doi: $10.1111 /$ jse. 12023

Lippitt, L., Fidelibus, M. W., and Bainbridge, D. A. (1994). Native seed collection, processing, and storage for revegetation projects in the western United States. Restor. Ecol. 2, 120-131. doi: 10.1111/j.1526-100x.1994.tb00049.x

Lishawa, S. C., Lawrence, B. A., Albert, D. A., Larkin, D. J., and Tuchman, N. C. (2019). Invasive species removal increases species and phylogenetic diversity of wetland plant communities. Ecol. Evol. 9, 6231-6244.

Liu, K., Baskin, J. M., Baskin, C. C., Bu, H., Du, G., and Ma, M. (2013). Effect of diurnal fluctuating versus constant temperatures on germination of 445 species from the eastern Tibet Plateau. PLoS One 8: e69364. doi: 10.1371/journal.pone. 0069364

Lobato de Magalhães, T., Rico, Y., Cabrera-Toledo, D., and Martínez, M. (2020). Plant functional connectivity of Nymphoides fallax in geographically isolated temporary wetlands in Mexican highlands. Aquat. Bot. 164:103215. doi: 10. 1016/j.aquabot.2020.103215

Lombard, K. B., Tomassi, D., and Ebersole, J. (2012). Long-term management of an invasive plant: lessons from seven years of Phragmites australis control. Northeastern Nat. 19, 181-193. doi: 10.1656/045.019.s614

Long, R. L., Gorecki, M. J., Renton, M., Scott, J. K., Colville, L., Goggin, D. E., et al. (2015). The ecophysiology of seed persistence: a mechanistic view of the journey to germination or demise. Biol. Rev. Camb. Philos. Soc. 90, 31-59. doi: 10.1111/brv.12095

López-Merino, L., Cortizas, A. M., and López-Sáez, J. A. L. (2011). Human-induced changes on wetlands: a study case from NW Iberia. Q. Sci. Rev. 30, 2745-2754. doi: 10.1016/j.quascirev.2011.06.004

Madsen, M. D., Davies, K. W., Boyd, C. S., Kerby, J. D., and Svejcar, T. J. (2016a). Emerging seed enhancement technologies for overcoming barriers to restoration. Restor. Ecol. 24, S77-S84.

Madsen, M. D., Hulet, A., Phillips, K., Staley, J. L., Davies, K. W., and Svejcar, T. J. (2016b). Extruded seed pellets: a novel approach for enhancing sagebrush seedling emergence. Native Plants J. 17, 230-243. doi: 10.3368/npj.17.3.230

Mahoney, J. M., and Rood, S. B. (1998). Streamflow requirements for cottonwood seedling recruitment-an integrative model. Wetlands 18, 634-645. doi: 10. 1007/bf03161678

Mainz, A. K., and Wieden, M. (2019). Ten years of native seed certification in Germany - a summary. Plant Biol. 21, 383-388. doi: 10.1111/plb.12866

Marin, M., Toorop, P., Powell, A. A., and Laverack, G. (2017). Tetrazolium staining predicts germination of commercial seed lots of European native species differing in seed quality. Seed Sci. Tech. 45, 151-166.

Marion, S. R., and Orth, R. J. (2010). Innovative techniques for large-scale seagrass restoration using Zostera marina (eelgrass) seeds. Restor. Ecol. 18, 514-526. doi: 10.1111/j.1526-100x.2010.00692.x

Marty, J. E., and Kettenring, K. M. (2017). Seed dormancy break and germination for restoration of three globally important wetland bulrushes. Ecol. Restor. 35, 138-147. doi: 10.3368/er.35.2.138
Masarei, M., Guzzomi, A. L., Merritt, D. J., and Erickson, T. E. (2019). Factoring restoration practitioner perceptions into future design of mechanical direct seeders for native seeds. Restor. Ecol. 27, 1251-1262. doi: 10.1111/rec. 13001

Matthews, J. W., McIntyre, S., Peralta, A. L., and Rodgers, C. (2019). Long-term assessment of alternative strategies for the restoration of floodplain forest in the presence of an invasive grass, Phalaris arundinacea. Wetlands 1-11. doi: 10.1007/s13157-019-01204-4

Mazerolle, M. J., Poulin, M., Lavoie, C., Rochefort, L., Desrochers, A., and Drolet, B. (2006). Animal and vegetation patterns in natural and man-made bog pools: implications for restoration. Freshw. Biol. 51, 333-350. doi: 10.1111/j.13652427.2005.01480.x

McGlathery, K. J., Reynolds, L. K., Cole, L. W., Orth, R. J., Marion, S. R., and Schwarzschild, A. (2012). Recovery trajectories during state change from bare sediment to eelgrass dominance. Mar. Ecol. Progr. Ser. 448, 209-221. doi: 10.3354/meps09574

McKay, J. K., Christian, C. E., Harrison, S., and Rice, K. J. (2005). "How local is local?"-A review of practical and conceptual issues in the genetics of restoration. Restor. Ecol. 13, 432-440. doi: 10.1111/j.1526-100x.2005.00 058. $\mathrm{x}$

McLane, C. R., Battaglia, L. L., Gibson, D. J., and Groninger, J. W. (2012). Succession of exotic and native species assemblages within restored floodplain forests: a test of the parallel dynamics hypothesis. Restor. Ecol. 20, 202-210. doi: 10.1111/j.1526-100x.2010.00763.x

McLaughlin, E. G. (1974). Autecological studies of three species of Callitriche native in california. Ecol. Monogr. 44, 1-16. doi: 10.2307/1942316

Meissen, J. C., Galatowitsch, S. M., and Cornett, M. W. (2015). Risks of overharvesting seed from native tallgrass prairies. Restor. Ecol. 23, 882-891. doi: $10.1111 /$ rec. 12295

Meissen, J. C., Galatowitsch, S. M., and Cornett, M. W. (2017). Assessing longterm risks of prairie seed harvest: what is the role of life-history? Botany 95, 1081-1092. doi: 10.1139/cjb-2017-0069

Meli, P., Benayas, J. M. R., Balvanera, P., and Ramos, M. M. (2014). Restoration enhances wetland biodiversity and ecosystem service supply, but results are context-dependent: a meta-analysis. PLoS One 9:e93507. doi: 10.1371/journal. pone.0093507

Meli, P., Isernhagen, I., Brancalion, P. H., Isernhagen, E. C., Behling, M., and Rodrigues, R. R. (2018). Optimizing seeding density of fast-growing native trees for restoring the Brazilian Atlantic Forest. Restor. Ecol. 26, 212-219. doi: $10.1111 /$ rec. 12567

Menges, E. S., Guerrant, E. O., and Hamzé, S. (2004). "Effects of seed collection on the extinction risk of perennial plants," Ex Situ Plant Conservation: Supporting Species Survival In The Wild, eds E. O. Guerrant, K. Havens, and M. Maunder (Washington, DC: Island Press), 305-324.

Merendino, M. T., Smith, L. M., Murkin, H. R., and Pederson, R. L. (1990). The response of prairie wetland vegetation to seasonality of drawdown. Wildlife Soc. Bull. 18, 245-251.

Merritt, D. J., and Dixon, K. W. (2011). Restoration seed banks-a matter of scale. Science 332, 424-425. doi: 10.1126/science. 1203083

Meyerson, L. A., Chambers, R. M., and Vogt, K. A. (1999). The effects of Phragmites removal on nutrient pools in a freshwater tidal marsh ecosystem. Biol. Invasions $1,129-136$.

Middleton, B. (2000). Hydrochory, seed banks, and regeneration dynamics along the landscape boundaries of a forested wetland. Plant Ecol. 146, 167-181.

Middleton, B. A. (2003). Soil seed banks and the potential restoration of forested wetlands after farming. J. Appl. Ecol. 40, 1025-1034. doi: 10.1111/j.1365-2664. 2003.00866.x

Miller, A., and Peters, J. (2010). AOSA/SCST Tetrazolium Testing Handbook. Washington, DC: USDA.

Miller, S. A., Bartow, A., Gisler, M., Ward, K., Young, A. S., and Kaye, T. N. (2011). Can an ecoregion serve as a seed transfer zone? Evidence from a common garden study with five native species. Restor. Ecol. 19, 268-276. doi: 10.1111/ j.1526-100x.2010.00702.x

Milotić, T., and Hoffmann, M. (2016). How does gut passage impact endozoochorous seed dispersal success? Evidence from a gut environment simulation experiment. Basic Appl. Ecol. 17, 165-176. doi: 10.1016/j.baae.2015. 09.007 
Minnesota Board of Water \& Soil Resources (2020). State Seed Mixes. Text. Available online at: http://www.bwsr.state.mn.us/native_vegetation/seed_ mixes/index.html (accessed July 21, 2020).

Mitsch, W. J., and Gosselink, J. G. (2015). Wetlands, 5th Edn. New York, NY: Wiley.

Moody, M. E., and Mack, R. N. (1988). Controlling the spread of plant invasions: the importance of nascent foci. J. Appl. Ecol. 25, 1009-1021.

Moor, H., Rydin, H., Hylander, K., Nilsson, M. B., Lindborg, R., and Norberg, J. (2017). Towards a trait-based ecology of wetland vegetation. J. Ecol. 105, 1623-1635. doi: 10.1111/1365-2745.12734

Moreno-Mateos, D., Power, M. E., Comín, F. A., and Yockteng, R. (2012). Structural and functional loss in restored wetland ecosystems. PLoS Biol. 10:e1001247. doi: 10.1371/journal.pbio.1001247

Moser, K., Ahn, C., and Noe, G. (2007). Characterization of microtopography and its influence on vegetation patterns in created wetlands. Wetlands 27, 1081-1097. doi: 10.1672/0277-5212(2007)27[1081:comaii]2.0.co;2

Mossman, H. L., Grant, A., and Davy, A. J. (2020). Manipulating saltmarsh microtopography modulates the effects of elevation on sediment redox potential and halophyte distribution. J. Ecol. 108, 94-106. doi: 10.1111/13652745.13229

Mulhouse, J. M., and Galatowitsch, S. M. (2003). Revegetation of prairie pothole wetlands in the mid-continental US: twelve years post-reflooding. Plant Ecol. 169, 143-159.

Neckles, H. A., Dionne, M., Burdick, D. M., Roman, C. T., Buchsbaum, R., and Hutchins, E. (2002). A monitoring protocol to assess tidal restoration of salt marshes on local and regional scales. Restor. Ecol. 10, 556-563. doi: 10.1046/j. 1526-100x.2002.02033.x

Nevill, P. G., Cross, A. T., and Dixon, K. W. (2018). Ethical seed sourcing is a key issue in meeting global restoration targets. Curr. Biol. 28, R1378-R1379.

Nevill, P. G., Tomlinson, S., Elliott, C. P., Espeland, E. K., Dixon, K. W., and Merritt, D. J. (2016). Seed production areas for the global restoration challenge. Ecol. Evol. 6, 7490-7497. doi: 10.1002/ece3.2455

Ngeve, M. N., Van der Stocken, T., Sierens, T., Koedam, N., and Triest, L. (2017). Bidirectional gene flow on a mangrove river landscape and betweencatchment dispersal of Rhizophora racemosa (Rhizophoraceae). Hydrobiologia 790, 93-108. doi: 10.1007/s10750-016-3021-2

Nikolaeva, M. (1977). "Factors controlling the seed dormancy pattern," in The Physiology and Biochemistry of Seed Dormancy and Germination, Ed. A.A. Khan (Amsterdam: FAO).

Nilsson, C., Brown, R. L., Jansson, R., and Merritt, D. M. (2010). The role of hydrochory in structuring riparian and wetland vegetation. Philos. Soc. 85, 837-858.

Noe, G. B., Fellows, M. Q. N., Parsons, L., West, J., Callaway, J., Trnka, S., et al. (2019). Adaptive management assists reintroduction as higher tides threaten an endangered salt marsh plant. Restor. Ecol. 27, 750-757.

O'Brien, E. L., and Zedler, J. B. (2006). Accelerating the restoration of vegetation in a Southern California salt marsh. Wetlands Ecol. Manag. 14, 269-286. doi: 10.1007/s11273-005-1480-8

Oliver, T. H., Heard, M. S., Isaac, N. J. B., Roy, D. B., Procter, D., Eigenbrod, F., et al. (2015). Biodiversity and Resilience of Ecosystem Functions. Trends Ecol. Evol. 30, 673-684.

Omernik, J. M. (1987). Ecoregions of the conterminous United States. Ann. Assoc. Am. Geograph. 77, 118-125.

Orsenigo, S., Gentili, R., Smolders, A. J. P., Efremov, A., Rossi, G., Ardenghi, N. M. G., et al. (2017). Reintroduction of a dioecious aquatic macrophyte (Stratiotes aloides L.) regionally extinct in the wild. Interesting answers from genetics. Aquatic Conserv. 27, 10-23. doi: 10.1002/aqc. 2626

Orth, R. J., Harwell, M. C., Bailey, E. M., Bartholomew, A., Jawad, J. T., Lombana, A. V., et al. (2000). A review of issues in seagrass seed dormancy and germination: implications for conservation and restoration. Mar. Ecol. Prog. Ser. 200, 277-288. doi: 10.3354/meps200277

Orth, R. J., and Moore, K. A. (1983). Seed germination and seedling growth of Zostera marina L.(eelgrass) in the Chesapeake Bay. Aquatic Bot. 15, 117-131. doi: 10.1016/0304-3770(83)90023-2

Ott, E. T., Galbraith, J. M., Daniels, W. L., and Aust, W. M. (2020). Effects of amendments and microtopography on created tidal freshwater wetland soil morphology and carbon. Soil Sci. Soc. Am. J. 84, 638-652. doi: 10.1002/saj2. 20057

Palma, A. C., and Laurance, S. G. W. (2015). A review of the use of direct seeding and seedling plantings in restoration: what do we know and where should we go? Appl. Veg. Sci. 18, 561-568. doi: 10.1111/avsc. 12173

Peach, M., and Zedler, J. B. (2006). How tussocks structure sedge meadow vegetation. Wetlands 26, 322-335. doi: 10.1672/0277-5212(2006)26[322: htssmv]2.0.co;2

Pearson, D. E., Ortega, Y. K., Runyon, J. B., and Butler, J. L. (2016). Secondary invasion: the bane of weed management. Biol. Conserv. 197, 8-17. doi: 10.1016/ j.biocon.2016.02.029

Pedrini, S., and Dixon, K. W. (2020). International principles and standards for native seeds in restoration. Restor. Ecol. 1-18.

Peralta, A. L., Matthews, J. W., and Kent, A. D. (2010). Microbial community structure and denitrification in a wetland mitigation bank. Appl. Environ. Microbiol. 76, 4207-4215. doi: 10.1128/aem.02977-09

Peralta, A. L., Muscarella, M. E., and Matthews, J. W. (2017). Wetland management strategies lead to tradeoffs in ecological structure and function. Elem Sci Anth 5:74. doi: 10.1525/elementa.253

Perillo, G. M. E. (ed.) (2009). Coastal Wetlands: An Integrated Ecosystem Approach, 1st Edn. Amsterdam: Elsevier.

Perry, L. G., and Galatowitsch, S. M. (2003). A test of two annual cover crops for controlling Phalaris arundinacea invasion in restored sedge meadow wetlands. Restor. Ecol. 11, 297-307. doi: 10.1046/j.1526-100x.2003.00174.x

Perry, L. G., and Galatowitsch, S. M. (2004). The influence of light availability on competition between Phalaris arundinacea and a native wetland sedge. Plant Ecol. 170, 73-81. doi: 10.1023/b:vege.0000019019.78909.f0

Perry, L. G., Galatowitsch, S. M., and Rosen, C. J. (2004). Competitive control of invasive vegetation: a native wetland sedge suppresses Phalaris arundinacea in carbon-enriched soil. J. Appl. Ecol. 41, 151-162. doi: 10.1111/j.1365-2664.2004. 00871.x

Pierce, A. R., and King, S. L. (2007). The effects of flooding and sedimentation on seed germination of two bottomland hardwood tree species. Wetlands 27 , 588-594. doi: 10.1672/0277-5212(2007)27[588:teofas]2.0.co;2

Pollux, B. J. A., Luteijn, A., Van Groenendael, J. M., and Ouborg, N. J. (2009). Gene flow and genetic structure of the aquatic macrophyte Sparganium emersum in a linear unidirectional river. Freshw. Biol. 54, 64-76. doi: 10.1111/j.1365-2427. 2008.02100.x

Polzin, M. L., and Rood, S. B. (2006). Effective disturbance: seedling safe sites and patch recruitment of riparian cottonwoods after a major flood of a mountain river. Wetlands 26, 965-980. doi: 10.1672/0277-5212(2006)26[965:edsssa]2.0. $\mathrm{co} ; 2$

Poschlod, P., and Rosbakh, S. (2018). Mudflat species: threatened or hidden? An extensive seed bank survey of 108 fish ponds in southern Germany. Biol. Conserv. 225, 154-163. doi: 10.1016/j.biocon.2018.06.024

Prach, K., Chenoweth, J., and del Moral, R. (2019). Spontaneous and assisted restoration of vegetation on the bottom of a former water reservoir, the Elwha River, Olympic National Park, WA, U.S.A. Restor. Ecol. 27, 592-599. doi: 10.1111/rec.12915

Pringle, A., Bever, J. D., Gardes, M., Parrent, J. L., Rillig, M. C., and Klironomos, J. N. (2009). Mycorrhizal symbioses and plant invasions. Ann. Rev. Ecol. Evol. Syst. 40, 699-715.

Prober, S. M., Byrne, M., McLean, E. H., Steane, D. A., Potts, B. M., Vaillancourt, R. E., et al. (2015). Climate-adjusted provenancing: a strategy for climateresilient ecological restoration. Front. Ecol. Evol. 3:65. doi: 10.3389/fevo.2015. 00065

Probert, R. J., Bogh, S. V., Smith, A. J., and Wechsberg, G. E. (1991). The effects of priming on seed longevity in Ranunculus sceleratus L. Ann. Bot. 76, 639-647.

Purcell, A. S. T., Lee, W. G., Tanentzap, A. J., and Laughlin, D. C. (2019). Fine root traits are correlated with flooding duration while aboveground traits are related to grazing in an ephemeral wetland. Wetlands 39, 291-302. doi: 10. 1007/s13157-018-1084-8

Qu, Y., Sun, G., Luo, C., Zeng, X., Zhang, H., Murray, N. J., et al. (2019). Identifying restoration priorities for wetlands based on historical distributions of biodiversity features and restoration suitability. J. Environ. Manag. 231, 1222-1231. doi: 10.1016/j.jenvman.2018.10.057 
Rantala-Sykes, B., and Campbell, D. (2019). Should I pick that? A scoring tool to prioritize and valuate native wild seed for restoration. Restor. Ecol. 27, 9-14. doi: $10.1111 /$ rec. 12827

Reinhardt Adams, C., and Galatowitsch, S. M. (2008). The transition from invasive species control to native species promotion and its dependence on seed density thresholds. Appl. Veg. Sci. 11, 131-138.

Renzi, J. J., He, Q., and Silliman, B. R. (2019). Harnessing positive species interactions to enhance coastal wetland restoration. Front. Ecol. Evol. 7:131. doi: $10.3389 /$ fevo.2019.00131

Reusch, T. B., Ehlers, A., Hämmerli, A., and Worm, B. (2005). Ecosystem recovery after climatic extremes enhanced by genotypic diversity. Estuar. Coasts 29, 159-164.

Reynolds, C., and Cumming, G. S. (2016). Seed traits and bird species influence the dispersal parameters of wetland plants. Freshw. Biol. 61, 1157-1170. doi: $10.1111 / \mathrm{fwb} .12776$

Reynolds, L. K., McGlathery, K. J., and Waycott, M. (2012). Genetic diversity enhances restoration success by augmenting ecosystem services. PLoS One 7:e38397. doi: 10.1371/journal.pone.0038397

Rice, K. J., and Emery, N. C. (2003). Managing microevolution: restoration in the face of global change. Front. Ecol. Environ. 1, 469-478. doi: 10.1890/15409295(2003)001[0469:MMRITF]2.0.CO;2

Rieger, J. P., Stanley, J., and Traynor, R. (2014). Project Planning and Management for Ecological Restoration. Berlin: Springer.

Rinella, M. J., Espeland, E. K., and Moffatt, B. J. (2016). Studying long-term, large-scale grassland restoration outcomes to improve seeding methods and reveal knowledge gaps. J. Appl. Ecol. 53, 1565-1574. doi: 10.1111/1365-2664. 12722

Rivière, S., Breman, E., Kiehn, M., Carta, A., and Müller, J. V. (2018). How to meet the 2020 GSPC target 8 in Europe: priority-setting for seed banking of native threatened plants. Biodivers. Conserv. 27, 1873-1890. doi: 10.1007/s10531-0181513-2

Rohal, C. B., Kettenring, K. M., Sims, K., Hazelton, E. L., and Ma, Z. (2018). Surveying managers to inform a regionally relevant invasive Phragmites australis research program. J. Environ. Manag. 206, 807-816. doi: 10.1016/j. jenvman.2017.10.049

Rosbakh, S., Hülsmann, L., Weinberger, I., Bleicher, M., and Poschlod, P. (2019). Bleaching and cold stratification can break dormancy and improve seed germination in Cyperaceae. Aquat. Bot. 2019:103128. doi: 10.1016/j.aquabot. 2019.103128

Rosbakh, S., Phartyal, S. S., and Poschlod, P. (2020). Seed germination traits shape community assembly along a hydroperiod gradient. Ann. Bot. 125, 67-78. doi: 10.1093/aob/mcz139

Ruhi, A., Catford, J. A., Cross, W. F., Escoriza, D., and Olden, J. D. (2019). "Chapter 3 - Understanding the Nexus Between Hydrological Alteration And Biological Invasions," in Multiple Stressors in River Ecosystems, eds S. Sabater, A. Elosegi, and R. Ludwig (Amsterdam: Elsevier), 45-64. doi: 10.1016/b978-0-12-8117132.00003-0

Saenger, P., and Siddiqi, N. A. (1993). Land from the sea: the mangrove afforestation program of Bangladesh. Ocean Coast. Manag. 20, 23-39. doi: 10.1016/0964-5691(93)90011-m

Saltonstall, K. (2002). Cryptic invasion by a non-native genotype of the common reed, Phragmites australis, into North America. Proc. Natl. Acad. Sci. U.S.A. 99, 2445-2449. doi: 10.1073/pnas.032477999

Santamaría, L. (2002). Why are most aquatic plants widely distributed? Dispersal, clonal growth and small-scale heterogeneity in a stressful environment. Acta Oecol. 23, 137-154. doi: 10.1016/s1146-609x(02)01146-3

Satterthwaite, W. H. (2010). Competition for space can drive the evolution of dormancy in a temporally invariant environment. Plant Ecol. 208, 167-185. doi: 10.1007/s11258-009-9696-y

Scheiner, S. M., and Holt, R. D. (2012). The genetics of phenotypic plasticity. X. Variation versus uncertainty. Ecol. Evol. 2, 751-767. doi: 10.1002/ece3.217

Schröder, R., and Prasse, R. (2013). Cultivation and hybridization alter the germination behavior of native plants used in revegetation and restoration. Restor. Ecol. 21, 793-800. doi: 10.1111/rec.12018

Schütz, W. (2000). Ecology of seed dormancy and germination in sedges (Carex). Perspect. Plant Ecol. Evol. Syst. 3, 67-89. doi: 10.1078/1433-8319-00005

Schütz, W., and Milberg, P. (1997). Seed dormancy in Carex canescens: regional differences and ecological consequences. Oikos 78, 420-428.
Schütz, W., and Rave, G. (2003). Variation in seed dormancy of the wetland sedge, Carex elongata, between populations and individuals in two consecutive years. Seed Sci. Res. 13, 315-322. doi: 10.1079/ssr2003148

Schwarz, C., Bouma, T. J., Zhang, L. Q., Temmerman, S., Ysebaert, T., and Herman, P. M. J. (2015). Interactions between plant traits and sediment characteristics influencing species establishment and scale-dependent feedbacks in salt marsh ecosystems. Geomorphology 250, 298-307. doi: 10.1016/j.geomorph.2015.09. 013

Scott, B., Baldwin, A. H., Ballantine, K., Palmer, M., and Yarwood, S. (2020). The role of organic amendments in wetland restorations. Restor. Ecol. 1-9. doi: $10.1111 /$ rec. 13179

Shipley, B., Keddy, P. A., Moore, D. R. J., and Lemky, K. (1989). Regeneration and establishment strategies of emergent macrophytes. J. Ecol. 77, 1093-1110.

Shipley, B., and Parent, M. (1991). Germination responses of 64 wetland species in relation to seed size, minimum time to reproduction and seedling relative growth rate. Funct. Ecol. 5, 111-118.

Shoemaker, C. M., and Ervin, G. N. (2020). Factors at multiple scales influence recruitment from herbaceous wetland seed banks in the lower Mississippi Alluvial Valley. Wetlands 1-12.

Silliman, B. R., Schrack, E., He, Q., Cope, R., Santoni, A., van der Heide, T., et al. (2015). Facilitation shifts paradigms and can amplify coastal restoration efforts. Proc. Natl. Acad. Sci. U.S.A. 112, 14295-14300. doi: 10.1073/pnas.151529 7112

Silvertown, J. (2008). The evolutionary maintenance of sexual reproduction: evidence from the ecological distribution of asexual reproduction in clonal plants. Int. J. Plant Sci. 169, 157-168. doi: 10.1086/523357

Sleeper, B. E., and Ficklin, R. L. (2016). Edaphic and vegetative responses to forested wetland restoration with created microtopography in Arkansas. Ecol. Restor. J. 34, 117-123. doi: 10.3368/er.34.2.117

Sloey, T., and Hester, M. (2019). The role of seed bank and germination dynamics in the restoration of a tidal freshwater marsh in the Sacramento-San Joaquin Delta. San Francisco Estuary Watershed Sci. 17, 1-16.

Smith-Cartwright, L. A., and Chow-Fraser, P. (2011). Application of the index of marsh bird community integrity to coastal wetlands of Georgian Bay and Lake Ontario, Canada. Ecol. Indicat. 11, 1482-1486. doi: 10.1016/j.ecolind.2011.03. 006

Smits, A. J. M., van Avesaath, P. H., and van der Velde, G. (1990). Germination requirements and seed banks of some nymphaeid macrophytes: nymphaea alba L., Nuphar lutea (L.) Sm. and Nymphoides peltata (Gmel.) O. Kuntze. Freshw. Biol. 24, 315-326. doi: 10.1111/j.1365-2427.1990.tb00712.x

Sobze, J.-M., Yücel, ÇK., Smreciu, A., and Gould, K. (2019). Effect of cold stratification on germination of 9 boreal sedges. Native Plants J. 20, 5-13. doi: $10.3368 /$ npj.20.1.5

Song, H. L., Sun, Z. G., Mou, X. J., and Zhao, J. Y. (2012). Salinity effect and seed priming treatments on the germination of Suaeda salsa in the tidal marsh of the Yellow River estuary. Afr. J. Biotechnol. 11, 7923-7933.

Soons, M. B., Brochet, A.-L., Kleyheeg, E., and Green, A. J. (2016). Seed dispersal by dabbling ducks: an overlooked dispersal pathway for a broad spectrum of plant species. J. Ecol. 104, 443-455. doi: 10.1111/1365-2745. 12531

Soons, M. B., de Groot, G. A., Ramirez, M. T. C., Fraaije, R. G. A., Verhoeven, J. T. A., and de Jager, M. (2017). Directed dispersal by an abiotic vector: wetland plants disperse their seeds selectively to suitable sites along the hydrological gradient via water. Funct. Ecol. 31, 499-508. doi: 10.1111/1365-2435. 12771

Sosnová, M., van Diggelen, R., and Klimešová, J. (2010). Distribution of clonal growth forms in wetlands. Aquat. Bot. 92, 33-39. doi: 10.1016/j.aquabot.2009. 09.005

Strobl, K., Moning, C., and Kollmann, J. (2019). Positive trends in plant, dragonfly, and butterfly diversity of rewetted montane peatlands. Restor. Ecol. 1-11.

Su, H., Zhu, T., Bai, X., Ni, L., Xie, P., and Zhang, X. (2018). Seed germination indicates adaptive transgenerational plasticity in a submerged macrophyte. Front. Plant Sci. 9:1592. doi: 10.3389/fpls.2018.01592

Suding, K. N. (2011). Toward an era of restoration in ecology: successes, failures, and opportunities ahead. Ann. Rev. Ecol. Evol. Syst. 42, 465-487. doi: 10.1146/ annurev-ecolsys-102710-145115

Sullivan, G. (2001). Establishing Vegetation in Restored and Created Coastal Wetlands. Washington, D.C: CRC Press. 
Sultan, S. E., Wilczek, A. M., Bell, D. L., and Hand, G. (1998). Physiological response to complex environments in annual Polygonum species of contrasting ecological breadth. Oecologia 115, 564-578. doi: 10.1007/s004420050554

Sutton-Grier, A. E., Ho, M., and Richardson, C. J. (2009). Organic amendments improve soil conditions and denitrification in a restored riparian wetland. Wetlands 29, 343-352. doi: 10.1672/08-70.1

Sweetman, A. C., Kettenring, K. M., and Mock, K. E. (2013). The pattern and structure of genetic diversity of Schoenoplectus maritimus: implications for wetland revegetation. Aquat. Bot. 104, 47-54. doi: 10.1016/j.aquabot.2012.09. 008

Taddeo, S., and Dronova, I. (2020). Landscape metrics of post-restoration vegetation dynamics in wetland ecosystems. Landscape Ecol. 35, 275-292. doi: 10.1007/s10980-019-00946-0

Thampanya, U., Vermaat, J. E., and Terrados, J. (2002). The effect of increasing sediment accretion on the seedlings of three common Thai mangrove species. Aquat. Bot. 74, 315-325. doi: 10.1016/s0304-3770(02)00146-8

Thomas, D. (2003). Modifying blender blades for seed cleaning. Native Plants J. 4, 72-73. doi: $10.3368 /$ npj.4.1.72

Tilley, D. J., and Hoag, J. C. (2006). Comparison of methods for seeding Nebraska sedge (Carex nebrascensis) and Baltic rush (Juncus balticus). Native Plants J. 7, 95-99. doi: $10.1353 /$ npj.2006.0018

Tilley, D. J., and St John, L. (2013). Hydroseeding improves field establishment of Nebraska sedge regardless of seed treatment. Native Plants J. 14, 89-94. doi: $10.3368 /$ npj.14.2.89

Tischew, S., Youtie, B., Kirmer, A., and Shaw, N. (2011). Farming for restoration: building bridges for native seeds. Ecol. Restor. 29, 219-222. doi: 10.3368/er.29. 3.219

Toth, L. A. (2017). Variant restoration trajectories for wetland plant communities on a channelized floodplain. Restor. Ecol. 25, 342-353. doi: 10.1111/rec.12427

Travis, S. E., Marburger, J. E., Windels, S., and Kubátová, B. (2010). Hybridization dynamics of invasive cattail (Typhaceae) stands in the Western Great Lakes Region of North America: a molecular analysis. J. Ecol. 98, 7-16. doi: 10.1111/ j.1365-2745.2009.01596.x

Triest, L., and Fenart, S. (2014). Clonal diversity and spatial genetic structure of Potamogeton pectinatus in managed pond and river populations. Hydrobiologia 737, 145-161. doi: 10.1007/s10750-013-1583-9

Tuckett, R. E., Merritt, D. J., Hay, F. R., Hopper, S. D., and Dixon, K. W. (2010). Dormancy, germination and seed bank storage: a study in support of ex situ conservation of macrophytes of southwest Australian temporary pools. Freshw. Biol. 55, 1118-1129. doi: 10.1111/j.1365-2427.2010.02386.x

Turner, R. E., and Lewis, R. R. (1996). Hydrologic restoration of coastal wetlands. Wetlands Ecol. Manag. 4, 65-72. doi: 10.1007/bf01876229

Tweedy, K. L. and Evans, R. O. (2001). Hydrologic characterization of two prior converted wetland restoration sites in eastern North Carolina. Trans. ASAE 44, $1135-1142$.

Unsworth, R. K. F., Bertelli, C. M., Cullen-Unsworth, L. C., Esteban, N., Jones, B. L., Lilley, R., et al. (2019). Sowing the seeds of seagrass recovery using hessian bags. Front. Ecol. Evol. 7:311. doi: 10.3389/fevo.2019.00311

Urbanska, K. M. (1997). "Safe sites-interface of plant population ecology and restoration ecology," in Restoration Ecology and Sustainable Development eds K.M. Urbanska, N.R. Webb and P.J. Edwards (Cambridge: Cambridge University Press).

van der Valk, A. G., and Baalman, M. A. (2018). Effects of seed treatments, delayed planting and groundwater levels on the restoration of sedge meadows. Wetlands 38, 875-883. doi: 10.1007/s13157-018-1036-3

van der Wal, R., Egas, M., Van der Veen, A., and Bakker, J. (2000). Effects of resource competition and herbivory on plant performance along a natural productivity gradient. J. Ecol. 88, 317-330. doi: 10.1046/j.1365-2745.2000. 00450.x

van Katwijk, M. M., Thorhaug, A., Marbà, N., Orth, R. J., Duarte, C. M., Kendrick, G. A. I, et al. (2016). Global analysis of seagrass restoration: the importance of large-scale planting. J. Appl. Ecol. 53, 567-578. doi: 10.1111/1365-2664.12562

Vander Mijnsbrugge, K., Bischoff, A., and Smith, B. (2010). A question of origin: where and how to collect seed for ecological restoration. Basic Appl. Ecol. 11, 300-311. doi: 10.1016/j.baae.2009.09.002

Varty, A. K., and Zedler, J. B. (2008). How waterlogged microsites help an annual plant persist among salt marsh perennials. Estuar. Coasts 31, 300-312. doi: 10.1007/s12237-007-9019-2
Vellend, M., Drummond, E. B., and Tomimatsu, H. (2010). Effects of genotype identity and diversity on the invasiveness and invasibility of plant populations. Oecologia 162, 371-381. doi: 10.1007/s00442-009-1480-0

Vivian-Smith, G., and Handel, S. N. (1996). Freshwater wetland restoration of an abandoned sand mine: seed bank recruitment dynamics and plant colonization. Wetlands 16, 185-196. doi: 10.1007/bf03160692

Vivrette, N. J., and Muller, C. H. (1977). Mechanism of invasion and dominance of coastal grassland by Mesembryanthemum crystallinum. Ecol. Monogr. 47, 301-318. doi: 10.2307/1942519

Wagner, E. J., and Oplinger, R. W. (2017). Effect of overwinter hydration, seed storage time, temperature, photoperiod, water depth, and scarification on seed germination of some Schoenoplectus, Polygonum, Eleocharis and Alisma species. Aquat. Bot. 136, 164-174. doi: 10.1016/j.aquabot.2016.10.004

Walck, J. L., Hidayati, S. N., Dixon, K. W., Thompson, K., and Poschlod, P. (2011). Climate change and plant regeneration from seed. Glob. Change Biol. 17, 2145-2161. doi: 10.1111/j.1365-2486.2010.02368.x

Wang, M., Wang, S., Wang, G., and Jiang, M. (2019). Importance of tussocks in supporting plant diversity in Carex schmidtii Meinsh. wetlands. Mar. Freshw. Res. 70, 807-815.

Webb, J., Miao, S., and Zhang, X.-H. (2009). Factors and mechanisms influencing seed germination in a wetland plant sawgrass. Plant Growth Regulat. 57, 243-250. doi: 10.1007/s10725-008-9341-0

Webb, J. A., Wallis, E. M., and Stewardson, M. J. (2012). A systematic review of published evidence linking wetland plants to water regime components. Aquatic Bot. 103, 1-14. doi: 10.1016/j.aquabot.2012.06.003

Weiher, E., and Keddy, P. A. (1995). The assembly of experimental wetland plant communities. Oikos 73, 323-335.

White, A., Fant, J. B., Havens, K., Skinner, M., and Kramer, A. T. (2018). Restoring species diversity: assessing capacity in the U.S. native plant industry. Restor. Ecol. 26, 605-611. doi: 10.1111/rec.12705

Whitham, T. G., Young, W. P., Martinsen, G. D., Gehring, C. A., Schweitzer, J. A., Shuster, S. M., et al. (2003). Community and ecosystem genetics: a consequence of the extended phenotype. Ecology 84, 559-573. doi: 10.1890/0012-9658(2003) 084[0559:caegac]2.0.co;2

Wienhold, C. E., and van der Valk, A. (1989). The impact of duration of drainage on the seed banks of northern prairie wetlands. Can. J. Bot. 67, 1878-1884. doi: 10.1139/b89-238

Willis, C. G., Baskin, C. C., Baskin, J. M., Auld, J. R., Venable, D. L., CavenderBares, J., et al. (2014). The evolution of seed dormancy: environmental cues, evolutionary hubs, and diversification of the seed plants. New Phytol. 203, 300-309. doi: 10.1111/nph.12782

Wimp, G. M., Young, W. P., Woolbright, S. A., Martinsen, G. D., Keim, P., and Whitham, T. G. (2004). Conserving plant genetic diversity for dependent animal communities. Ecol. Lett. 7, 776-780. doi: 10.1111/j.1461-0248.2004. 00635.x

Winikoff, S. G., Larkin, D. J., Meier, S. L., and Finlay, J. C. (2020). Vegetation trajectories of restored agricultural wetlands following sediment removal. Restor. Ecol. 28, 612-622.

Wolters, M., Garbutt, A., Bekker, R. M., Bakker, J. P., and Carey, P. D. (2008). Restoration of salt-marsh vegetation in relation to site suitability, species pool and dispersal traits. J. Appl. Ecol. 45, 904-912. doi: 10.1111/j.1365-2664.2008. 01453.x

Yarwood, S. A., Baldwin, A. H., Gonzalez Mateu, M., and Buyer, J. S. (2016). Archaeal rhizosphere communities differ between the native and invasive lineages of the wetland plant Phragmites australis (common reed) in a Chesapeake Bay subestuary. Biol. Invasions 18, 2717-2728. doi: 10.1007/ s10530-016-1144-z

Young, T. P., Stuble, K. L., Balachowski, J. A., and Werner, C. M. (2017). Using priority effects to manipulate competitive relationships in restoration. Restor. Ecol. 25, S114-S123.

Zedler, J. B., and Kercher, S. (2004). Causes and consequences of invasive plants in wetlands: opportunities, opportunists, and outcomes. Crit. Rev. Plant Sci. 23, 431-452. doi: 10.1080/07352680490514673

Zedler, J. B., and Kercher, S. (2005). Wetland resources: status, trends, ecosystem services, and restorability. Annu. Rev. Environ. Resour. 30, 39-74. doi: 10.1146/ annurev.energy.30.050504.144248

Zedler, J. B., Nordby, C. S., and Kus, B. E. (1992). The Ecology of Tijuana Estuary. Milford, CT: LLC. 
Zeldin, J., Lichtenberger, T. M., Foxx, A. J., Williams, E. W., and Kramer, A. T. (2020). Intraspecific functional trait structure of restoration-relevant species: implications for restoration seed sourcing. J. Appl. Ecol. 57, 864-874. doi: 10.1111/1365-2664.13603

Zhao, S., Zhang, R., Liu, Y., Yin, L., Wang, C., and Li, W. (2017). The effect of storage condition on seed germination of six Hydrocharitaceae and Potamogetonaceae species. Aquat. Bot. 143, 49-53. doi: 10.1016/j.aquabot.2017. 09.005

Zirbel, C. R., and Brudvig, L. A. (2020). Trait-environment interactions affect plant establishment success during restoration. Ecology 101:e02971.
Conflict of Interest: The authors declare that the research was conducted in the absence of any commercial or financial relationships that could be construed as a potential conflict of interest.

Copyright $\odot 2020$ Kettenring and Tarsa. This is an open-access article distributed under the terms of the Creative Commons Attribution License (CC BY). The use, distribution or reproduction in other forums is permitted, provided the original author(s) and the copyright owner(s) are credited and that the original publication in this journal is cited, in accordance with accepted academic practice. No use, distribution or reproduction is permitted which does not comply with these terms. 